\title{
In Vitro Modeling of Tissue-Specific 3D Microenvironments and Possibile Application to Pediatric Cancer Research
}

\author{
N. Steimberg ${ }^{1, \dagger}$, G. Mazzoleni ${ }^{1, \dagger}$, E. Ciamporcero ${ }^{2}$, C. Ullio ${ }^{2}$, M. Daga $^{2}$, G. Barrera ${ }^{2}$ and \\ S. Pizzimenti ${ }^{*}$,
}

${ }^{1}$ Unit of Anatomy and General Physiopathology, Department of Clinical and Experimental Sciences, School of Medicine, University of Brescia, viale Europa 11, 25123, Brescia, Italy

${ }^{2}$ Unit of Experimental and Clinical Pathology, Department of Clinical and Biological Sciences, University of Torino, Corso Raffaello 30, 10125, Turin, Italy

\begin{abstract}
A large body of evidence indicates that three dimensional (3D) cancer models are superior to two-dimensional (2D) ones in better representing the in vivo phenomena. Indeed, 3D models allow recapitulating in vitro the in vivo features observed in solid tumors (e.g. cell polarity, cell-cell/cell-matrix interactions, biochemical/metabolic gradients, anchorage-independent growth and hypoxia). Moreover, it is well established that the microenvironment plays a fundamental role in regulating tumor development and behavior, including drug resistance. Thus, innovative models able to mimic this complexity represent attractive tools in cancer research. In this review article, we provide a comprehensive review of the application of 3D culture systems in pediatrics' cancer research. In particular, 3D in vitro/ex vivo models of the most common pediatric tumors, such as leukemias, lymphomas and malignancies of the nervous system, will be considered.
\end{abstract}

Keywords: Three dimensions (3D), microenvironment, pediatric cancer, pediatrics' oncology.

\section{INTRODUCTION}

For almost all cancers, if death rates continue to decline, statistics indicate that the number of new cases/year and the number of mortality deaths are still too high. In 2014, in effect, the estimate of cancer incidence in the USA will be about 1.66 million new cases, while deaths will reach the number of 585.720 patients [1]. In Europe (2012), the predicted number of new cases of cancer was 3.45 million, and 1.75 million deaths [2], while, for 2013, the predicted number of cancer deaths decreased to 1.31 million [3]. For children and adolescents (birth to 19 years old) in USA, for 2014 , the predicted number of newly diagnosed cases of cancer is 15,780 and about 1,960 deaths from cancer will occur. The annual incidence rate of cancer for this young population is 186.6 per 1 million [4]. Altogether, these data demonstrate that we are far away from assuring the cure of cancer patients.

Tumorigenesis is a multistep process, and it was initially considered as a succession of mutations occurring in oncogenes, in tumor suppressors and, ultimately, in microRNAs, all events which lead to a successive uncontrolled proliferation of tumor cells, induction of angiogenesis and lymphangiogenesis, and further metastatic processes [5]. The high hetero-

*Address correspondence to this author at the Unit of Experimental and Clinical Pathology, Department of Clinical and Biological Sciences, University of Turin, Corso Raffaello 30, 10125, Turin, Italy; Tel: +39-011-6707763; Fax: +39-0116707753; E-mail: stefania.pizzimenti@unito.it

${ }^{\dagger}$ Authors equally contributed to the work geneity of cancers between individuals is thought to be multifactorial due to genetic diversity, the presence of cancer stem cells, and the impact of the tumor microenvironment [6]. It is well-known that genotypic alterations alone are not sufficient to explain tumor progression and metastatic processes, and that the tumor microenvironment can be profoundly involved in regulating tumor growth, local invasion of the stroma, angiogenesis/lymphangiogenesis, intra/extravasation, metastasis, drug resistance, as well as tumor reversion [7-11].

In the present review, we have considered the concept of the tumor microenvironment in adult solid neoplasms and in the in vitro models available to study the main hallmarks of adults' cancer, and childhood malignancies. There are some differences between adults' and childhood's tumors; for example, the incidence of tumor types is different. In adults, carcinomas/solid tumors are the most frequent types of neoplasms (about 80\%), whereas in childrens/ adolescents, leukemia accounts for about the $30 \%$ of the total tumors, followed by malignancies of the Central Nervous System (CNS) (20-25\%), by lymphomas (16\%) and neuroblastomas (7.6\%) [12]. In adults, parenchymal cells are mature and terminally differentiated, and then only a limited number of cells highly proliferate, whereas in young people (and mostly in children), a certain number of organs/tissues present an incomplete terminal maturation, and their cells, instead of differentiating, continue to proliferate and die. This increases the difficulty of chemotherapeutic 
treatment of the tumor's proliferating cells without side effects on healthy tissues. Finally, in children, tumors may require quite a few events to progress, as compared to the adult ones [13]. In the last section of the review we have illustrated and discussed specific 3D cell-based systems suitable for modeling the most common pediatric tumors, such as leukemias, lymphomas, CNS's cancers and neuroblastoma.

\section{THE IMPORTANCE OF THE TUMOR MICROENVIRONMENT}

The normal tissue's microenvironment is characterized by specific architecture, extracellular matrix (ECM) and parenchymal cell types, as well as by the presence of vasculature, immune cells, and specific physical and biochemical cues (e.g. interstitial pressure, biomechanical factors, cell metabolism's
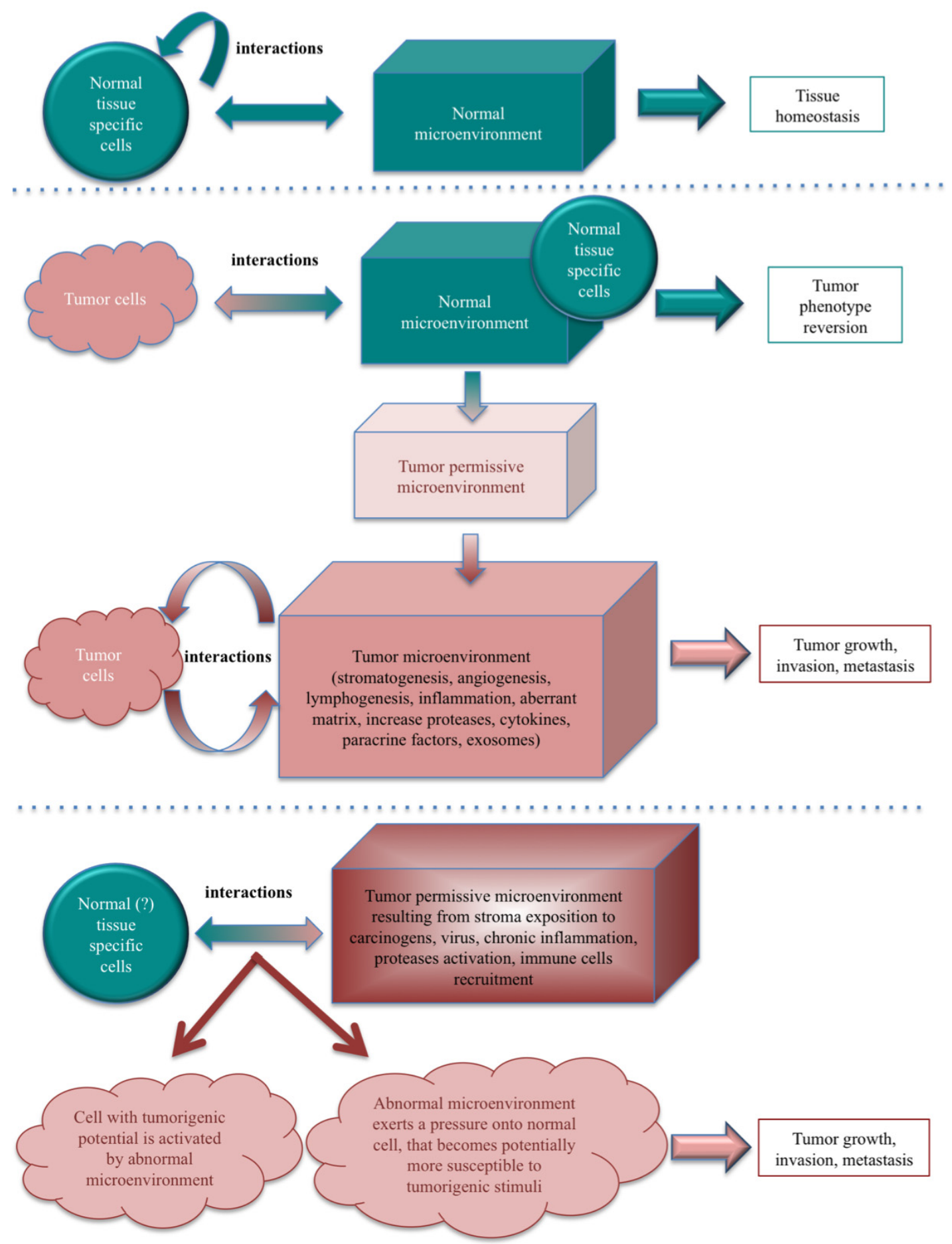

Figure 1: The stroma microenvironment is an active contributor to tissue homeostasis and pathology. Microenvironment exerts a selective pressure onto tumor cells, as well as tumor cells that interact with the microenvironment may selectively constraint it to progress toward tumorigenic process or to regress to "normal" state. 
products, anti-oxidative agents, gas components, $\mathrm{pH}$ ). Tissue homeostasis results from the balance between cell-cell/cell-matrix interactions and from the composition and organization of the stroma. Alterations of cell (normal versus malignant) or/and microenvironment stability/features can result either in the malignant phenotype reversion or in tumor growth (Figure 1). In such reversible configurations, the cell microenvironment is often proposed as a "tumor suppressor" element, since it is thought to limit cancer progression. Different cellular and macromolecular entities are implicated in tumor suppression (e.g. immune, epithelial, or myoepithelial cells, proteases, junctions such as desmosomes) [9, 14-16]. Drugs such as tamoxifen can also suppress the tumor phenotype by interfering with the mammary ECM [17]. On the other hand, when the microenvironment is modified, its composition/architecture varies, in such a way that it becomes more permissive to tumor growth, and begins to play a crucial role in regulating tumor evolution and propagation. In the pre-tumor/tumor microenvironment, it is really possible to observe a loss of tissue architecture, aberrant cells and ECM (in quality and quantity, desmoplasia), neoangiogenesis/lymphangiogenesis, inflammatory and fibrotic processes, recruitments of tumor-associated fibroblasts and macrophages, infiltration of leukocytes, high presence of cytokines, growth factors, hormones, morphogens and proteolytic enzymes. Tumor cells and inflammation are often intimately co-involved in the further tumor development. Indeed it is well-known that the local inflammatory tumor microenvironment has an impact on cancer development; its role is so fundamental to tumor progression that it now represents a hallmark of cancer [6]. Moreover, recent findings have demonstrated that tumors can affect distant tissues, by inducing a chronic inflammatory response in vivo, leading to increased systemic levels of oxidative DNA damage [18]. The stroma itself may possess an oncogenic impact, independently of the presence of tumor cells [19]. Moreover, the tumor microenvironment is also involved in the drug resistance process that it is an important cause of cancers'relapse and fatal onset.

The components of the tumor microenvironment vary according to the tumor type, but usually two main compartments can be identified: i) the cellular compartment consisting of tissue specific cells (fibroblasts, pericytes, smooth muscle cells, endothelial cells, mesenchymal cells, immune and/or inflammatory cells) and ii) the matrix-related compartment comprising a solid phase (extracellular matrix) and a more "fluid-phase" (soluble factors: cytokines, chemokines, trophic factors). There is a dynamic interplay between tumor cells, normal cells and their surrounding matrix that involves biomechanical and biochemical signals, integrated into complex molecular interactions and intra- and extracellular signaling networks [20], outlined in Figure 2.

\subsection{The Main Cellular Actors in the Host Stroma}

\subsubsection{The Non Malignant Cell Compartment}

The reciprocal interactions between malignant cells and their neighboring host stromal cells actively regulate tumor features, growth, invasion, angiogenesis and metastasis. These interactions can also be mediated by paracrine factors. Moreover, tumor cells recruit/activate non-malignant cells (bone marrowderived cells, inflammatory and immune cells, cancer associated fibroblasts, pericytes, endothelial cells), which interfere with the normal, physiologic microenvironment. The (abnormal) tumor microenvironment itself favors tumor progression by altering cell function and ECM cues.

Bone marrow derived Mesenchymal stem cells (MSCs) present an innate tropism for tumor [21] as a result of tumor cells' chemotaxis, mediated, for example, by growth factors (VEGF, EGF, HGF, bFGF and PDGF). The MSCs homing can also be regulated by chemokines and proteases (urokinase, metalloproteases). MSCs can be recruited by tumor cells, and when they reach the tumor microenvironment, they differentiate in tumor-associated fibroblasts, pericytes and myofibroblasts [22-23]. Reciprocally, these mesenchymal cells can attract tumor cells in the bone marrow district. Their exact role as tumor suppressor or promoter is still in discussion because of the complexity of their intercellular and molecular interactions with the tumor microenvironment [24].

Inflammatory cells. Chronic inflammation are recognized as an important step in cancer progression [25]. The inflammatory infiltration in tumors results from the recruitments of leukocytes mediated by cytokines and chemokines synthesized by malignant cells. This process is important for the further angiogenic process. Inflammatory and immune response is intimately linked in determining tumor behavior.

Immune cells. Among all functions of the immune system, the immune-surveillance should, as a rule, also eliminate cancer cells. Cells dedicated to such targets 


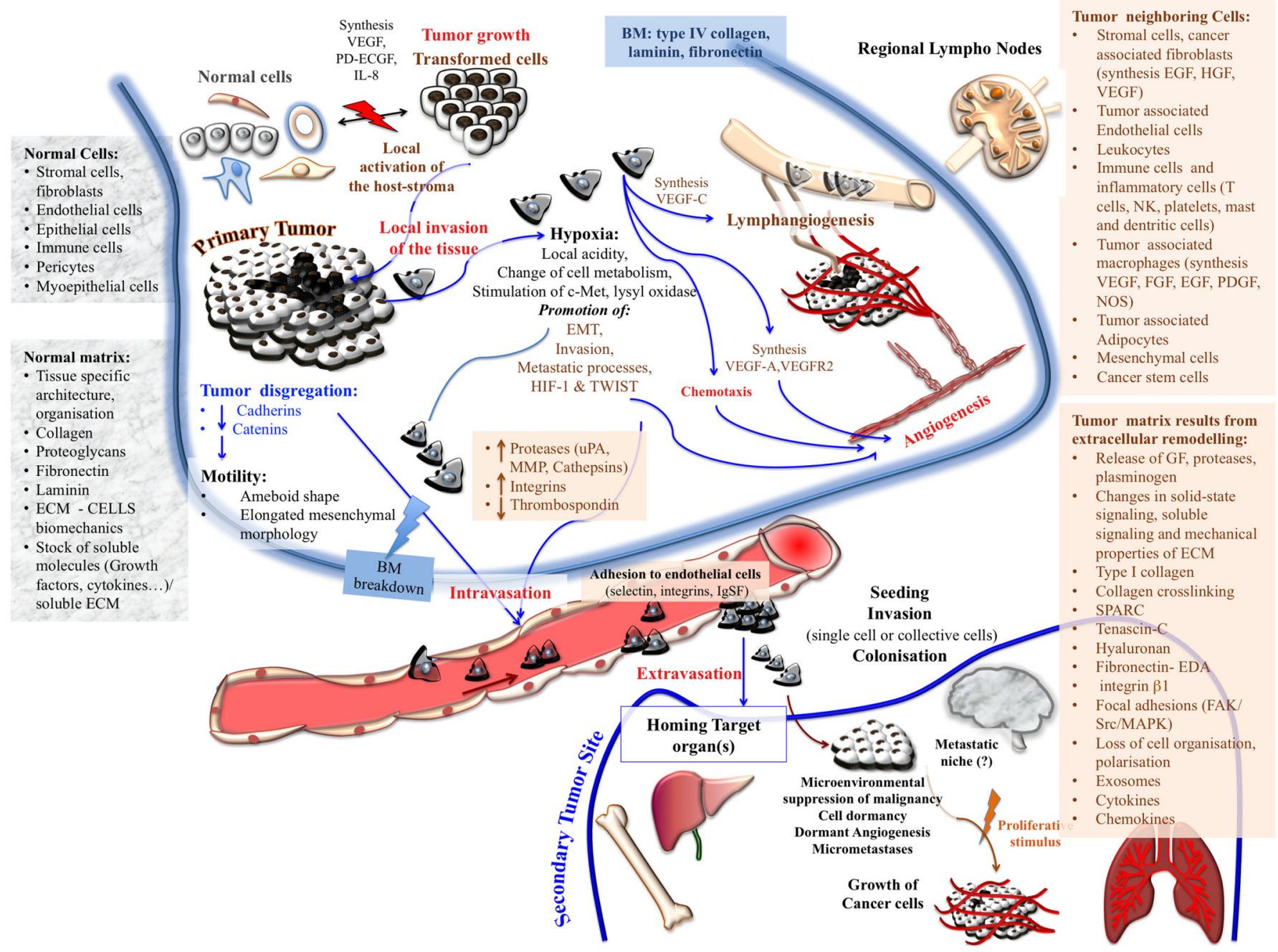

Figure 2: The main cancer hallmarks. The heterogeneous tumor microenvironment embraces a cohort of cells (stromal cells, immune and inflammatory, stem cells, etc.), gradients of bioactive molecules, macromolecular, biophysical and biochemical cues (ECM, growth factors, cytokines, metabolites), which allow interactions and resulting signaling networks to contribute to tumor progression. Whereas normal cells and ECM may be conducive to tissue homeostasis and tumor phenotype reversion, the tumor microenvironment leads to a cascade of events that usually finishes with the dissemination of tumor derived cells into other tissue districts of the body. These changes regard either cells behaviors and features (for example switching from normal fibroblasts or myoepithelial and epithelial cells to myofibroblasts, cancer associated fibroblasts, mesenchymal cells etc) or activation of an adaptive response by altering cell metabolism and syntheses (from oxidative to glycolytic pathways) as well as gene expression (hypoxia inducible factor 1 (HIF-1), proteases, integrins, cadherins, growth factor, cytokines, chemokines, proangiogenic morphogens), due to hypoxic and acidic environment and resulting in ECM remodeling, basal membrane collapse, activation of angiogenesis/lymphangiogenesis and subsequent migratory/metastatic processes to target organs. Tumor and tumor microenvironment characteristics vary between cancer types, patients and in the course of the pathology. For leukemia, for example, osteoblastic/endosteal and hematopoietic stem cells niches, in addition to the cohort of cells already described, play a crucial role.

are mainly lymphocytes $\mathrm{T}$, monocytes/macrophages, mast cells and natural killers (NK). However, in addition to preventing tumor growth, the immune system is involved in the opposite induction of cell transformation (tumorigenesis), the so called process of cancer immune-editing [26]. A way by which immune cells can promote tumorigenesis is the increase in MMP synthesis, involved in ECM remodeling and, therefore, in the remolding of the stromal microenvironment [27].

Tumor Associated Macrophages (TAMs). TAMs are present in many tumors as a significant cell population; moreover their high number also corresponds to a poor prognosis' marker in many 
cancers. Monocytes are recruited into the tumor by chemotaxis (mainly by chemokines and factors such as CCL2, CCL-5, CCL8, CXCL-12, VEGF, MIP1a, and MIF). Macrophages can produce VEGF-C and VEGFD, MMP-2 and IL-8, playing, by this way, an important role in lymphangiogenesis and ulterior metastatic processes mediated by the lymphatic system. They can also produce a number of angiogenic growth factors, cytokines and proteases, which are implicated in tumor progression. Macrophages also interact with tumor cells, reciprocally exchanging/sensing biochemical cues (mediated by CXCL-12 and EGF or NO and CXCL-12) [28, 29].

Dendritic cells. These cells are physiologically involved in the innate and adaptive responses of the immune system. Moreover, they are recruited in the tumor environment regulate the angiogenic process by secreting TNFa, TGF $\beta$, GM-CSF and IL-12 [30]. Whereas they can play a crucial role in inhibiting tumor growth, their normal activities and maturation can be hindered by tumor associated macrophages, reducing in such a way the immune surveillance necessary to counteract tumor growth [31-32]. The capability of this cell type to regulate angiogenesis might also be linked to their predisposition to differentiate into endotheliallike cells in response to tumor signals [33]. Moreover, because they also secrete metalloproteases (MMPs) and their inhibitors (TIMP), they can play a role in tumor progression and metastasis [34]. Mast cells are immune cells involved in immunological and inflammatory responses. They can either down regulate the tumorigenic process by secreting interleukins, or promote tumor growth by interfering with stroma-epithelium interaction and ECM degradation, encouraging angiogenesis (e.g. by secreting factors such as VEGF, FGF-2 and IL8) and lymphangiogenesis, and inhibiting antitumor activity $[10,35]$.

Cancer-associated fibroblasts. Within a tumor mass, different types of sub-populations of fibroblasts are usually found (i.e. dormant fibroblasts, myofibroblasts, cancer-associated fibroblasts), that are molecularly different from their normal fibroblastic counterparts [36]. They synthesize great amounts of ECM components (type I collagen and fibronectin) and are largely responsible for desmoplasia. These abnormal fibroblasts secrete matrix proteases and relative inhibitors (whose crucial role is either linked to their proteases' activity, or to their non-proteolytic activity), which are paracrine factors that regulate tumor growth (EGF, TGF $\beta$, HGF, PDGF, IL1, IL6, IL8), as well as angiogenesis (VEGFA and FGF) [37]. Cancer-associated fibroblasts produce CXCL12 that allow the recruitment of endothelial progenitors from the bone marrow [38]. These fibroblastic cells originate mainly from the trans-differentiation of resident fibroblasts, but also from bone marrow mesenchymal cells [36]. One part of these cells probably also derived from the epithelial-mesenchymal transition (EMT) that takes place during tumor invasion. Cancer-associated fibroblasts represent a noticeable part of the tumor mass and influence tumorigenesis (initiation, progression, invasive and metastatic processes) [9, 39]. They sustain cancer cells' survival by removing their metabolic wastes [40], and their presence also represents an unfavorable parameter for cancer patients [41].

Adipocytes - cancer associated adipocytes. These cells are responsible for energy storing, and can directly provide lipids to tumor cells; adipocytes also play an important role in regulating the tissue microenvironment, because of their capacity to synthesize a number of biologically active molecules, referred to as adipokines, and which include cytokines, growth factors, hormone-like factors and chemokines [42]. These tumor-associated adipocytes were shown to promote the growth of malignant tumors in breast, colon and prostate tissues) [43-45]. Moreover, adipose stromal cells might also be recruited in the tumor microenvironment and contribute to the differentiation of progenitors into pericytes and adipocytes [46].

Tumor associated endothelial cells. These cells are involved in the angiogenic process that promotes cancer progression. Moreover, the hypoxic environment within the tumor's tissue, together with neoplastic, stromal and inflammatory cells secreting VEGF, stimulate the angiogenic switch of quiescent endothelial cells to proliferating cells. This leads to the building of a new, abnormal architecture and poorly functional blood vessels $[47,48]$, that fail to become quiescent because they lost the adequate control of pro- and anti-angiogenic factors. Besides, these neoendothelial cells synthesize growth factors favoring tumor (IGF, PDGF, GM-CSF).

Perycites. The recruitment of pericytes into the tumor's microenvironment is mediated by PDGF-B receptor expression [49]. These cells participate in the maintenance of functional vessels, while their reduced number in tumor's vessels seem to sustain intravasation processes. 


\subsubsection{The Malignant Cell Compartment}

The hypothesis of Cancer stem cells (CSCs) existence is based on tumor's heterogeneity; more recent evidence seems to indicate that these tumor cells' subsets might be liable to tumor progression [50, 51]. Their presence was shown in leukemia as wells as in solid tumors, even if at a lesser level $[52,53]$. The hypotheses regarding their origin are still under investigation [50]. The heterogeneity in CSCs' (and in their progeny's) phenotype and function between patients and tumor's type, as well as inside the same individual tumor, increases the difficulty in better characterizing them and targeting them for therapy. Moreover, these cells might be present in a premetastatic niche, either as Epithelial to Mesenchymal Transition (EMT) derived cells, or as a trigger for the recruitment of metastatic cells in a hospitable niche [52].

All the host cells are, at the beginning, without apparent malignant properties, but, probably due to the wrong microenvironment pressure, to their dynamic intercellular interactions, and to their active communication with tumor cells, they express an atypical phenotype [54].

\subsection{ECM Compartment}

The ECM, in addition to representing a support structure for cells, is also responsible for regulating vital biological processes (such as differentiation, proliferation, viability, migration, cell interactions/communication), and serves as reservoir for a number of factors. Matrix properties that are directly involved in the regulation of such events are: i) its own biochemical composition (e.g. collagen, laminin, fibronectin, tenascin $\mathrm{C}$, hyaluronic acid (HA), proteoglycans, cadherins, integrins, osteopontin, galectins, fibulin-1), ii) the presence of matrix proteases involved in ECM remodeling/breakdown (MMPS, urokinase plasminogen activators, cathepsins), iii) its organization (at macro-, micro- and nanoscale), or iv) its capacity to interact with biologically active molecules (growth factors, cytokines, chemokines), usually stored for interacting with ECM macromolecules, and also v) its biomechanical properties, that are directly linked to the regulation of gene expression. MMPs are enzymes involved in ECM turnover, and, in such a way, within the tumor context, they play a noticeable role as regulators of tumor progression [34, 55]. ECM also presents mechanical properties (stiffness, compliance) that regulate cell behavior, owing to mechanotransduction pathways and mechanosensing cell capacities. These ECM characteristics influence (prevent or favor) tumor invasion, as a consequence of alterations in tensegrity, namely in the equilibrium in continuous tension and discontinuous compression forces existing at the matrix, cell, and intracellular levels and that stabilizes cell functions [56-58]. Alterations in ECM stiffness/ compliance were shown, for example, in murine breast where: in normal murine breast elastic modulus is about $170 \mathrm{~Pa}$, in the tumor surrounding stroma it increases up to $920 \mathrm{~Pa}$ whereas it reaches about 4000 $\mathrm{Pa}$ in tumor [59].

Integrins function as mechano-transducers and influence gene expression and cell behavior. Integrins show a crucial, and often contradictory, role on regulation cell migration, invasion, proliferation and survival; they orchestrate host cells' behavior and thus tumor progression [59-61]. The integrin subtypes that are more frequently overexpressed in tumors are, for example, $\alpha v \beta 3, \alpha v \beta 5, \alpha 5 \beta 1, \alpha 4 \beta 1, \alpha v \beta 6$ and $\alpha 6 \beta 4$. The expression and clustering of integrins in turn can be modulated by the ECM stiffness, resulting in a more tumorigenic phenotype [59]. In addition to the tissue architecture stability, the matrix integrity is fundamental too and regulates the release of pro and antiangiogenic cues, by mean of its type IV collagen, fibronectin and thrombospondin-1 components [62, 63]. In effect, when ECM proteins are hydrolyzed by matrix proteolytic enzymes, pro- and anti-angiogenic factors, and other ECM-sequestered factors, turn out to be bioavailable $[62,64]$.

Tumor microenvironment was shown to be also involved in drug resistance. Resistance to chemotherapeutics may be determined by tissue organization, cell adhesions/interactions, ECM viscosity (and relative drug diffusion in the interstitial space), hypoxic and acidic intratumoral context, or by soluble mediators produced by tumor, host cells and their cross-talk [8, 9].

Another factor that points to the importance of the microenvironment in tumor progression is evinced in the appearance of second cancers after radiotherapy. Radiotherapies may have opposite effects on the tumor: whereas they locally present the expected antitumor effect, they can also alter the tumor microenvironment (increase in growth factors', cytokines' or tumor promoting factors' secretion), and might contribute, in such a way, to local invasion and metastatic processes in pre-irradiated zones [65]. This was confirmed by several observations, which suggests that the effect of radiation depends on a 
number of parameters (the characteristics of the irradiated tissue, the age of the patient, the dose and dose rate, the volume of targeted tissue, and hereditary factors) [66]. The effects of radiation might be mediated by genomic instability of cells that survive to the therapy, by the selection of hypoxic resistant cells, by the activation of the tumor microenvironment's production of growth factors and proteases, as well as by the possible radio-resistance of a subset of cancer stem cells [67].

\section{DEVELOPING MORE BIOMIMETIC CANCER MODELS}

In order to overcome the high incidence of tumors, to increase the efficacy of treatments (in addition to traditional surgery, chemotherapy and radiotherapy), and to reduce therapy-related side-effects and resistance, it is necessary that oncology research points to the development of new therapeutic strategies, (such as, for example, specific immunotherapy and molecular-targeted therapy), in order to better focus onto specific molecular/microenvironmental objectives [68]. This will, further, provide a more specific patient-targeted therapy, as tumorigenesis reflects a complex and heterogeneous situation, closely related also to individual characteristics. Unfortunately, whereas in preclinical studies alternative strategies were shown to be efficient, when translated to patient's treatment, they often showed an unsuccessful outcome. This may be due to the "gap" still existing between in vivo (animal-based) models (immunocompromised or transgenic/humanised mice), in vitro/ ex vivo culture models, and in humans (i.e. clinical application); thus, the lack of physiologically relevant models for the study of human tissues' functions and behavior is now well recognized, at the different levels of basic and applied research and risk assessment [69]. Moreover, in addition to ethical reasons, the application of the 3R's [70] recently included into most of the new international legislative bodies (see, for example, EU REACH Regulation, 2006 - at http: //ec. europa.eu/enterprise/sectors/chemicals/reach/index_en .htm - and European Directive 2010/63 EU - available at http: //eur-lex.europa.eu/LexUriServ/LexUriServ.do? uri=OJ: L: 2010: 276: 0033: 0079: en: PDF), encourage/ compel the reduction / elimination in the use of animal models in basic and applied research studies. In order to overcome such limitations, new and relevant in vitro models need to be developed. Because of the complexity, variability and heterogeneity of tumors (intra-tumor's physical, biochemical cues and molecular gradients -zonation of tumor- and differences between patients and tumor types), it clearly emerges that a battery of humanderived in vitro/ex vivo models must be developed/optimized to better respond to clinical needs.

In conclusion, it clearly appears that it is important (and urgent) to increase our knowledge of the tumor microenvironment, in order to better control and target it. This is the reason why in vitro models, able to reproduce all the fundamental cues and features of the tissue-specific native microenvironment, the complex network of cell-cell's/cell-matrix's, and cell-bioactive molecules' interactions, need to be developed. In vitro models should, then, take into consideration (and resume) the complexity of the tumor microenvironment. To this aim, it should be better to consider a tumor as a complex organ, in which a wide variety of cells coexist, that secrete a high quantity of soluble factors (growth factors, cytokines, chemokines, proteolytic enzymes, etc.), that interfere with cells' behavior but, also, with the physiological tissue remodeling process or with tensegrity; these last, in turn, control/may affect cells' behavior and, consequently, ECM features.

\subsection{D versus 3D Cancer Models}

Cell culture systems were initially designed in order to simplify the complex in vivo context, and they allow a specific control on environmental conditions and have the advantage of being more reproducible and cheaper than in vivo models. The majority of in vitro models are characterized by the maintenance of cells in 2 dimensions (2D) (artificial, rigid, plastic surface of traditional Petri dishes). Several mechanistic in vitro studies have been performed in such 2D culture systems, which are very distant from the physiologic in vivo conditions where cells develop and function; even if they represent a fundamental source of information into key biologic phenomena linked to neoplastic transformation (elucidation of specific signaling pathways' perturbation, genetics of oncogenes and tumor suppressor genes, mechanisms of action of tumor promoters and mutagens, etc.), these systems are often too limited to correctly mimic the complexity and heterogeneity of the tumor/tumor's microenvironment interaction, and fail in simulating real cell behavior in living organisms. Whereas, in vivo, cells naturally grow in a three dimensional (3D) context that, besides allowing the correct polarization and orientation of cells, provide them with the surrounding matrix, that represents a dynamic environment that furnish cells with an architectural support, temporally-regulated 
biochemical and biomechanical cues, and specific interactions with neighboring cells and matrix; whereas, in the classical 2D in vitro configuration, culture conditions impose an unnatural cell polarization, a loss of cell organization - with disrupted interactions between cells and cell/ECM, caused by the disruption of normal tissue architecture - and the loss of native $E C M$, with the consequence of affecting, in such a way, biomechanical cues and critical biological processes, such as cell proliferation, viability, migration, differentiation, and specific cross-talks, as well [69, 71-74]. Moreover, the "flat" 2D conditions, lacking native ECM, does not mimic the natural tumor's microenvironment that normally interfere with drug bioavailability, rendering, in such a way, a hardly effective extrapolation of drug activity from in vitro studies to clinical applications. As for normal tissues, culture models may be more or less complex, and reflect, more or less accurately, the in vivo specificities of the native tissue. Briefly, from the simpler to the more complex in vitro models, biological studies can be performed on isolated subcellular fractions, microsomes, single isolated cells, cells in suspensions, 2D cultured cells (homotypic or heterotypic cultures), and 3D cultures (multilayered confluent cells, multicellular spheroids, with or without scaffolds, in mono- or heterotypic configurations, tissue slices, organotypic systems) $[69,75,76]$. Often, the more the system model is simplified, the less it is able to maintain, at long-term, cells' viability and functions. As in the case of untransformed, normal cells, cancer cells also, when maintained in 3D culture, exhibit behavior and gene expression patterns closer to the in vivo conditions [7779]. Already in the '70s, Bissel's group and others demonstrated how tissue architecture, 3D context, composition of ECM, correct cell polarization, and epithelial adhesion are fundamental for reproducing relevant in vitro models able to mirror, as much as possible, the physiological or pathological features of breast tissue $[80,81]$. They showed that the 3D culture better recapitulates different tumors' behavior than did 2D configurations. For example, it was demonstrated that the 3D context was able to reverse tumor phenotype to normal (with specific pathways' inhibitors), and to sustain the cross-talk between integrin and EGF receptors; moreover, tumor cells cultured in 3D showed, with respect to 2D-cultured controls, an increased pro-angiogenic capacity and a higher resistance to IFN, chemotherapeutic agents and irradiation [82, 83]. Other parameters that are highly modified by the switch from $2 \mathrm{D}$ to $3 \mathrm{D}$ configuration are the cell migration, cell morphology and cell signaling $[84,85]$. Some other advantages of the 3D vs. 2D culturing techniques for investigating tumor's behavior are also illustrated and discussed by Ferrarini et al. [86]. Moreover, some biological events that can be preferentially studied in 3D models are presented in Table 1.

Table 1: Examples of in vitro Models Applied to the Study of the Main Cancer Hallmarks

\begin{tabular}{|c|c|c|c|}
\hline Biological events & Models & Outcomes & References \\
\hline $\begin{array}{l}\text { Cell invasion, } \\
\text { migration, motility } \\
\text { and metastasis }\end{array}$ & $\begin{array}{l}\text { - Matrigel }{ }^{\mathrm{TM}} \text { based assay } \\
\text { - Type / collagen assay } \\
\text { - Type / collagen overlaying } \\
\text { 3D assay } \\
\text { - Multicellular spheroids } \\
\text { - } \text { Acellular matrices } \\
\text { - Co-cultures of bone } \\
\text { sections with tumor cells in } \\
\text { - Coller tube system. } \\
\text { Cell Lung Carcinoma Cells } \\
\text { - } \text { with bronchial mucosa } \\
\text { - Nanoimprinted scaffolds }\end{array}$ & $\begin{array}{l}\text { - The outgrowth of cells from multicellular spheroids (consents to } \\
\text { isolate the migration process from the complex multicellular } \\
\text { context). } \\
\text { - Hydrogel based assays allow investigation of factors and } \\
\text { pathways involved in migration as well as dynamics regulating } \\
\text { this process. } \\
\text { - ECMs produced by fibroblasts at different stages of tumor } \\
\text { progression allow to reproduce the matrix/tumor cells } \\
\text { interactions and their involvement in } \\
\text { tumorigenesis/invasiveness. } \\
\text { - Co-culture systems seem efficient in reproducing } \\
\quad \text { bone tropisms of tumor cells originating from breast or } \\
\quad \text { prostate. } \\
\text { - bronchial mucosa invasion by lung carcinoma cells. } \\
\text { Microfluidic models allow interesting studies of metastatic } \\
\text { of target organ etc). A limit of these models (for metastasis } \\
\text { investigation) is that it is necessary to know in advance the } \\
\text { main step of the different processes (intra-, extravasation, } \\
\text { target organs). Concerning the easier tumor growth, cell } \\
\text { migration approaches, they allow a good survival of 3D } \\
\text { cocultures. } \\
\text { Micro- and nano-engineering represent the future of tissue } \\
\text { engineering for conducting cell behavior, up today few of these } \\
\text { models are applied to tumor biology. }\end{array}$ & $\begin{array}{c}{[242,319-} \\
329]\end{array}$ \\
\hline
\end{tabular}


Table 1 Continue ......

\begin{tabular}{|c|c|c|c|}
\hline Biological events & Models & Outcomes & References \\
\hline Angiogenesis & 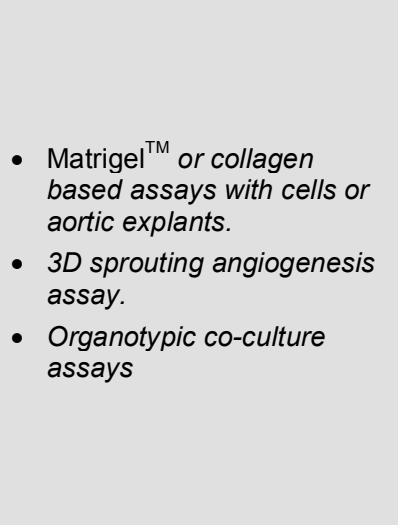 & $\begin{array}{l}\text { - Outgrowth or migration of cells is evaluated after different } \\
\text { period of time. } \\
\text { - Co-culture assays, where fibroblasts can serve as ECM } \\
\text { producer; the three dimensionality is mainly provided by the } \\
\text { fibroblast layer. } \\
\text { - After some days, sprouting/branchings or neo-capillaries (tube } \\
\text { like structures) may be observed in response to biological } \\
\text { stimuli (growth factors). } \\
\text { - It is important to choose the good (anatomical) source of } \\
\text { endothelial cells. } \\
\text { - None of the actual in vitro model accurately reproduce the } \\
\text { whole in vivo process of angiogenesis, mainly because of the } \\
\text { complexity of the neovascularisaztion events that, for example, } \\
\text { also includes the regulation of the neoangiogenesis by the fluid } \\
\text { flows. }\end{array}$ & $\begin{array}{l}{[11,99,116} \\
330-334]\end{array}$ \\
\hline $\begin{array}{l}\text { Drug } \\
\text { responsiveness/ } \\
\text { resistance / testing }\end{array}$ & $\begin{array}{l}\text { - Multicellular aggregates in } \\
\text { static or dynamic conditions } \\
\text { - Multilayered postconfluent } \\
\text { culture } \\
\text { - Hydrogel based cultures } \\
\text { - Tissue slices }\end{array}$ & $\begin{array}{l}\text { - Cells express more differentiated functions and resemble more } \\
\text { closely to in vivo situation. } \\
\text { Cell maintained in 3D often exhibit an increase resistance to } \\
\text { chemotherapeutic drugs as compared to cells maintained in 2D } \\
\text { configuration. According to the tumor cell type and the } \\
\text { configuration of the 3D models, cells can gain or lose drug } \\
\text { sensitization reproducing the native features of tumor. } \\
\text { - Synthetic scaffold/hydrogels leading to better monitor ECM } \\
\text { mechanics may allow to take into account the influence of the } \\
\text { physicochemical properties of ECM onto drug bioavailability } \\
\text { and diffusion. }\end{array}$ & $\begin{array}{l}{[71,87,116-} \\
117,335-339]\end{array}$ \\
\hline Tumor growth & $\begin{array}{l}\text { 3D free floating multicellular } \\
\text { spheroids (mono and } \\
\text { heterotypic), gel embedded } \\
\text { spheroids, in static or } \\
\text { dynamic culture conditions }\end{array}$ & $\begin{array}{l}\text { - Several tumor features (cell proliferation, intercellular contacts } \\
\text { and interactions, cell-matrix interactions, hypoxia, HIF-1a } \\
\text { expression and relative consequences) can be reproduced. } \\
\text { - Coculture in dynamic conditions also consent to recreate, at } \\
\text { least in part, the complex bone marrow microenvironment and } \\
\text { are applicable in studying hematopoietic niche in health or } \\
\text { illness. }\end{array}$ & $\begin{array}{l}{[90,115,120} \\
122,337]\end{array}$ \\
\hline $\begin{array}{l}\text { Microenvironment } \\
\text { influence }\end{array}$ & $\begin{array}{l}\text { - 3D culture in/onto natural } \\
\text { and/or synthetic scaffolds }\end{array}$ & $\begin{array}{l}\text { - ECM mechanics (compliance, stiffness) can be better controlled } \\
\text { by using synthetic scaffolds. }\end{array}$ & $\begin{array}{l}{[77,78,99} \\
115-121]\end{array}$ \\
\hline Tumor reversion & $\begin{array}{l}\text { - Culture of tumor cell in/on } \\
\text { normal basal membrane or } \\
\text { in low stiffness }\end{array}$ & $\begin{array}{l}\text { - ECM leads to the recovery of "normal" cell behavior (slower } \\
\text { growth, epithelial like polarization ecc). }\end{array}$ & {$[59,340-341]$} \\
\hline
\end{tabular}

\subsection{D Tumor Models}

A first step in increasing the complexity of the microenvironment is the culture of multilayered postconfluent cells. In these systems, cells are maintained on V-bottomed microplates and grow as multilayers (up to 15 layers can be assembled), harboring properties that look like those of native tumor, thus suggesting that these models could be suitable for drug screening [75]. The 3D culture of multilayered cells was further developed by Simon and collaborators [87], by using breast cancer-derived cells, but a deeper characterization of cell model's properties is required in order to ascertain the capability of correctly reproducing the tumor environment.

The 3D culture models of tumor cells that are at present most extensively used are represented by the culture of multicellular spheroids (MSs), that consists in the self-aggregation of (neoplastic) cells in multicellular, rounded aggregates (spheroids). These spheroids can be obtained by different methods (e.g. coated-plates, hanging drops, liquid-overlay techniques, hydrogel templates, micro-patterned wells). Spheroids can also spontaneously form in dynamic bioreactors (such as spinner flasks or Rotary Cell Culture System's $\mathrm{RCCS}^{\mathrm{TM}}$ - devices), or by microfluidics-based technologies, with or without scaffolds [88-90]. Spheroids show a particular cellular microenvironment, since they are able to reproduce, at least in part, key 3D tissue-like features known to influence cell behavior and gene expression (i.e. organization, zonation, ECM deposition, cell-cell and cell-matrix interactions). Due to a low mass transfer condition, these peculiar tissue-like 3D constructs display various similarities depending on tumor mass, and, in particular, gradients of nutrients, metabolites, catabolites's wastes and growth factors, associated with low $\mathrm{O}_{2}$, and high $\mathrm{CO}_{2}$ concentrations 
[91]. If spheroids grow up to $500 \mu \mathrm{m}$ diameter, a central necrotic core appears, reproducing in such a way the hypoxic and necrotic processes usually observed in solid tumors [92, 93]. Cells grown in MSs usually exhibit a lower sensitivity to therapeutic drugs and a more specific response to particular therapeutic agents as a result of new signaling pathways activation [94, 95]. In living organisms, in addition to the involvement of particular proteins (such as the drug/ABC transporters, enzymes and HMGB1), or to the increased efficiency in DNA repairing mechanisms and resistance to apoptosis, multi-drug resistance may also be due to ECM's organization and composition (desmoplasia), cell-cell adhesion and lower growth rate, which are parameters that mirror the in vivo context, in which tissue architecture and cell adhesion, as well as the absence of blood vessel and the low hydrostatic and osmotic pressure, limit the diffusion of therapeutic drugs $[83,96,97]$.

In addition, when cells grow in spheroids, they form an outer layer of proliferative cells and a more central quiescent zone where cells do not proliferate. Since chemotherapeutic drugs often target the dividing cells, this quiescence may justify the "resistance" to cytostatic drugs observed in MSs $[89,98]$. Furthermore, in vivo, drug bioavailability and delivery are also regulated by the ECM's attributes (configuration, composition, structure), that can alter/disrupt cell signaling [99, 100]. Heterotypic MSs more closely mimic the heterogeneity of tumors and the heterotypic inter-relations between cells, and, in addition to monotypic culture, they allow the investigation of important tumor endpoints such as angiogenesis, tumor cell migration and invasion, and drug responsiveness [101]. Examples of heterotypic spheroids may encompass tumor cells with fibroblasts, macrophages, and endothelial cells [102, 103]. For example, heterotypic MSs of melanoma cell lines and endothelial cells allowed to demonstrate that-invasion and angiogenesis processes may be potentiated by cadherins [104]. Co-cultures of fibroblasts and cheratinocytes can be also used to form 3D models of reconstructed skin, in which melanoma or other skin cancer cells can be embedded. Within these 3D skin reconstructed models, melanoma's cells from different stages of tumor progression have the same properties they show in the patients' skin. For instance, melanoma cells at the initial radial growth phase are unable to invade the dermis from the epidermis, whereas, in advanced stages such as the vertical growth phase and the metastatic phase, cells readily invade the dermis [105]. A number of recent studies have assessed the effects of novel anti-cancer drugs in 3D models of reconstructed skin $[105,106]$. Alternatively, multicellular aggregates can be formed by a unique cell type for generating tissue-like structures and, then, they can be further co-cultured with tumor' cells, in order to observe the reciprocal interaction of both cell types [107]. Important limits of these MS-based models are: i) some cells are not able to aggregate in order to form multicellular spheroids; ii) the spatial arrangement of cells could be casual and could not match the in vivo co-localization of specific cells; iii) cell ratio inside multicellular spheroids does not always reflect the real proportion of cells in the tumor's environment; iv) cocultures should involve different tumor cells (in addition to non-tumor cells), in order to better mimic tumor's heterogeneity; v) 3D MS's culture require very efficient dynamic bioreactors, which can allow a long-term culture of the spheroids, so that the maturation of the neo-synthesized ECM may take place and achieve characteristics close to the situation in vivo, vi) cell amplification and aggregation can be time consuming experimental procedures, vii) while heterotypic cultures can mimic the reciprocal cross-talk of tumor's with neighboring cells (thus mirroring the in vivo tumor context better than in other in vitro model systems), these co-culture conditions make it more difficult to distinguish among all cell types, which of them is responsible of the biological effects observed in response to external stimuli.

\subsection{Mimicking the ECM}

One of the most important challenges for finding the 3D culture model more suitable for each specific experimental purpose, is to also engineer ECM, so that neo-constituted matrices are obtained with structural and biochemical features similar to those of the specific native matrix of the tissue under study. This means that it is important to reproduce both the mechanical (architectural, topographic, physical features and tissue mechanics: ECM dimensionality, collagen fiber size and orientation, ECM stiffness/compliance), and the biochemically- and biologically-active ECM's characteristics (ligand-binding sites) [108, 109]

One of the most used "biological" ECM is that extracted from Engelbreth-Holm-Swarm (EHS) mouse sarcoma's cells (most diffused trade names: Matrigel ${ }^{\mathrm{TM}}$, Cultrex $\mathrm{BME}^{\mathrm{TM}}$ ). This tumor-derived matrix has the characteristics of a basement membrane-like matrix, since it is mainly composed of type IV collagen, laminin, perlecan, nidogen/entactin and trophic factors $[110,111]$. It was shown to sustain 3D cultures of 
breast-, colon-, prostate-, and lung-derived tumor cells, allow expression of some of their original tissuespecific functions and to allow co-culturing, thus confirming, for example, that, in an in vitro prostate tumor model, stromal cells might activate tumor growth and invasion's process [74, 79, 112-114]. However, this extractive matrix, besides being variable in quality from batch to batch, fails, at least in part, in recreating the native mechanics of normal basement membrane, and does not correspond at all to the other matrices found within connective tissues and parenchyma. This mouse-derived matrix does not represent the ECM of all tumors, since, as reported before, each tumor possesses its own characteristics, which also vary in accordance with its evolution. Therefore, it is of interest to be able to isolate/customize/bioengineer the tissue/tumor- specific 3D matrices. Several strategies were developed to respond to this need, and a number of natural (hyaluronan, chitosan, collagen, alginate, fibrin, laminin-rich ECM proteins) or synthetic matrix/gel/ hydrogels/scaffolds were proposed (e.g. Poly(lactidecoglycolide), poly(lactic acid), poly(vinyl alcohol),

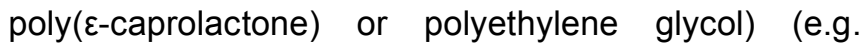
Poly(lactide-coglycolide), poly(lactic acid), poly(vinyl alcohol), poly( $\varepsilon$-caprolactone) or polyethylene glycol) $[77,78,99,115-121]$. One advantage of scaffold-based strategies is that it is possible to better manage matrix stiffness/compliance, porosity, and biochemical composition.

Among the various available ECM substitutes, collagen gels seem to represent an interesting option, especially if cross-linked with other matrix components [120]. Unfortunately, as in the case of Matrigel ${ }^{\mathrm{TM}}$, analogous, collagen hydrogels also have a noteworthy difference between the different preparations. In collagen gels, monotypic or heterotypic cultures can be developed, thereby increasing the possibility of better mirroring the in vivo conditions by integrating tumor's neighboring cell types [122]. Culture of fibroblasts in collagen gels have allowed a better understanding of the reciprocal interactions between cells and ECM, and, namely, the regulation of cell behavior mediated by the mechanical properties of ECM [123].

Type I collagen can be electrospun and, therefore, it can support cell growth. By acting on ECM biomechanics, it also provides oriented fiber alignmentsignals - or topological cues - known to regulate cell behavior. Hydrogels with a mixture of Matrigel $^{\mathrm{TM}}$ and type I collagen were shown to present stiffness properties ranging from normal to breast tumor tissue [59], and to sustain multicellular cultures and tissue-like morphogenesis [124]. Scaffolds formed of chitosan and alginate's mixture were shown to better favor the tumor progression of human-derived glioma cells than does each component alone [125]. Moreover, scaffolds/ hydrogels can be functionalized to favor more native cell behavior and more tissue-like function [99]. Hence, the choice of natural matrix-derivatives and configurations is also of importance, since, as in in vivo tumors, it undoubtedly influences cell behavior, from cancer reversion to promotion steps.

Alternatively, some in vitro models have been developed, by using decellularized matrices and, even if their use for cancer investigations is still limited, they could represent an important source of natural ECM. The major advantages of these decellularized matrices are that they can be prepared from different tissues, maintaining the $3 \mathrm{D}$ architecture of the native tissue and its original composition. These matrices were used for investigating the behavior of breast tumor-derived cells (proliferation, morphology, migration) and their drug sensitivity, that were shown to be quite similar to what can be obtained with the in vivo xenograft models [126]. In particular ECM, prepared by using different explants obtained from human intestinal mucosae (ranging from healthy colon to colorectal carcinoma), can also be used to investigate tumor cell's behavior in response to a more or less permissive microenvironment [127]. The main limit of this ECM is that they are natively complex, their exact composition is not fully known, and this may render difficult the interpretation of cell's behavior in response to a particular stimulus.

Synthetic matrices could also be regarded as the future of engineering tumor microenvironments, but the high number of biomaterials proposed in the literature need to be further optimized before being effectively applied in the tumor biology fields [128]. In effect, in the design of these matrices, several key factors should be taken into account, and, among them, landscape/ topography, fiber orientation, porosity (macro-, micro-, nanoscale conditioning), matrix viscoelasticity, matrix remodeling, and growth factors' and cytokines' binding sites. It is now easier than before to monitor / engineer matrix compositions (collagen, proteoglycans, other macromolecules), to include adhesion peptides (the integrin-binding Arg-Gly-Asp motif $R G D$, for example), to functionalize the surface of the scaffolds/hydrogels, to control biomaterials' mechanical properties [129], to model cell behavior in space and time, and to develop patterning strategies providing a biomaterial substrate conducive to support a particular geometric configuration. 


\subsection{Which Cells for 3D Cultures?}

Another important point that it is necessary to keep in mind is the choice of the cells to be used in the $3 \mathrm{D}$ in vitro models. There is a high number of available cell lines that express some specific tumor features, and a number of them have already been well characterized [130]. Nevertheless, the native heterogeneity of tumors renders difficult the choice of one suitable cell line, since cell lines could represent only one clone among the whole mosaics of tumor cells. Moreover, the use of freshly isolated cells from patients' tumors allows to work on primary cells, by avoiding the phenotypic drift related to the culture conditions. However, the risk exists that the experimental procedures employed for cell isolation and culture may exert a selective pressure, giving rise to clones able to survive and to eliminate more labile cells, with the consequent loss of the native cell heterogeneity typical of neoplastic tissue.

Interesting approaches based on the use of the native tissues were developed for different tumorderived tissues, overcoming, in such a way, the limitation related to cell isolation. These models are mainly represented by the culture of tissue slices or explants. Both these approaches allow the maintenance of the 3D tissue architecture, cell organization, matrix arrangement and composition, i.e. the complexity and heterogeneity of the tissue microenvironment. Moreover, both models allow working with human tissues (healthy- or tumor-derived tissues), solving the problem of interspecies differences that occur when animal models are used. This allows a more accurate prediction of the human in vivo cell behavior. Tissue slices were applied to cancer research in order to analyze therapeutic strategies and drug responses, as well as to gain new insight into the cell invasion process [131-133].

The more complex culture of tissue explants is appealing, since it offers the possibility of maintaining a more consistent section of tissue (thickness of more than $1 \mathrm{~mm}$ vs. $250 \mu \mathrm{m}$, for explants and tissue slices, respectively), thus increasing the possibility of preserving multilayer cell-cell and cell-matrix interactions [134]. Once correctly established and optimised, the model based on the use of tissue explants can allow longterm experimental procedures, thus representing a potent tool for preclinical investigation of therapeutic drugs targeted on individual patients. Today, the limit of these tissue slices- and explants-based models is the difficulty of optimizing the protocols of ex vivo culture, since 3D hydrodynamic conditions and high mass transfer are essential to sustain cell viability and native tissue functions.

Even if 3D cultures lack some aspects of the whole in vivo environment (e.g. systemic interrelations, immune response, hormonal inputs), they differ from 2D conditions, that offer more cell signaling information and less tissue-like features. With respect to 2D cultures, 3D models also better resemble animal in vivo models, bridging the gap between these two models, routinely used in cancer research. However, 3D in vitro lex vivo models still need to be optimized in order to overcome a number of limitations (Table 2). Among these limits, time consuming procedures and lack of reproducibility are the most urgent to solve, especially if these models will be used for drug screening purposes in pharmaco-toxicology field.

\section{LEUKEMIA}

Leukemia is the most common neoplasms in children and accounts for almost a third $(30 \%)$ of the tumors at diagnosis. Pediatric leukemias occur predominantly as acute leukemias, with acute lymphatic leukemias (ALL) representing the largest proportion (about $80 \%$ of all childhood leukemias) followed by the acute myeloid leukemias (AML, accounting for about $10 \%$ of all childhood leukemias) $[12,135]$. Leukemic cells inhibit hematopoiesis and infiltrate organs, eliciting the main clinical manifestations, such as anemia, bleeding and infections. Leukemic infiltration of lymph nodes, the spleen and the liver may alter their function and increase their size. Moreover, testes and CNS are often infiltrated by leukemia cells [136].

\subsection{Normal and Leukemic BM Microenvironment}

Several lines of evidence suggest that the bone marrow (BM) microenvironment plays a central role in the control of leukemia initiation, progression, and drug-resistance. The BM microenvironment consists a complex 3D highly vascularized architecture of multiple cellular components, soluble factors, all embedded in an ECM. The cellular component of BM can be divided into hematopoietic cells and the BM stromal cells (BMSCs). The hematopoietic stem cells (HSCs) are localized within the $\mathrm{BM}$ in two main niches: the osteoblastic niche (at the bone-BM interface) and the vascular niche (around the blood vessels). This 
Table 2: Main Shortcomings of 3D Culture Models and Proposals to Overcome them

\begin{tabular}{|c|c|}
\hline \multicolumn{2}{|r|}{ Shortcomings of $3 D$ culture models } \\
\hline Weakness & Counteractions to circumvent limitations \\
\hline $\begin{array}{l}\text { Models are often limited to short } \\
\text { term studies }\end{array}$ & - Develop effective bioreactors \\
\hline Whole tumor complexity is lost & $\begin{array}{l}\text { - Increase multicellular cultures approaches } \\
\text { - Increase microengineering approaches (microfluidics, microfabrications, micropatterning) } \\
\text { - Recover the native tissue mechanical cues } \\
\text { - These necessary developments, are difficult to reach because of the high variability between } \\
\text { tumor types, and inside tumor itself; a promising strategy may be to develop patient-biopsies } \\
\text { cultures, but they will be hard to handle in the high throughput context and they are poorly } \\
\text { available }\end{array}$ \\
\hline $\begin{array}{l}\text { Differences/variability between } \\
\text { 3D models in pre-clinical assays }\end{array}$ & $\begin{array}{l}\text { - Standardization of procedures and methods } \\
\text { - Standardization for preparation of good/constant quality scaffold/hydrogels } \\
\text { - The high number of available models and their relative strength and weakness force an aware } \\
\text { choice of the model for defined application (because of tumor heterogeneity and the actual lack of } \\
\text { perfect in vitro model, it is necessary to keep in mind that each in vitro system could model only } \\
\text { partly the conditions in living organisms) }\end{array}$ \\
\hline $\begin{array}{l}\text { Application of Tissue engineering } \\
\text { to tumor biology }\end{array}$ & $\begin{array}{l}\text { - Microfluidic approaches offers good prospective applications, but need further investigation to } \\
\text { render them easy to use, less expensive when thinking to high-throughput applications }\end{array}$ \\
\hline $\begin{array}{l}\text { Lack of suitable methods for } \\
\text { drug screening in high } \\
\text { throughput contexts }\end{array}$ & $\begin{array}{l}\text { - Both cell models and analytic protocols should be optimized and standardized. } \\
\text { - Models should consent to cover as much as possible the whole tumor /tumor microenvironment } \\
\text { characteristics (these models are still lacking) } \\
\text { - Scaffold/hydrogel/ medium etc (all components of the in vitro models should be tested for its } \\
\text { interactions with drugs to eliminate experimental bias) }\end{array}$ \\
\hline Loss of systemic regulations & $\begin{array}{l}\text { This gap could be bridge with the development of multi-compartmental bioreactors or bioreactor } \\
\text { organized as parallel or series networks (but use of animals will remain necessary even if reduced) }\end{array}$ \\
\hline Cost-effectiveness & $\begin{array}{l}\text { - Standardization of procedures } \\
\text { - Optimization of techniques for biological investigations } \\
\text { - Research of more suitable models to reach equilibrium between reliability and cost }\end{array}$ \\
\hline
\end{tabular}

localization is required to maintain their self-renewal capacity [137, 138]. BMSCs include several cell types, such as endothelial cells, perivascular reticular cells, osteoclasts, osteoblasts, mesenchymal stem or stromal cells (MSCs), all of them important for HSC maintenance. Moreover, other stromal cells (glial cells, neuronal cells, adipocytes) can regulate hematopoiesis [139].

MSCs play an important role in BM, since they give rise to several cell types, including endothelial cells, neurons, astrocytes, myocytes, chondroblasts, osteoblast and adipocytes [140, 141]. This heterogeneous population is responsible for the production and deposition of ECM, formed mainly by type I and IV collagens, proteoglycans, glycosaminoglycans such as $\mathrm{HA}$, and glycoproteins such as fibronectin, osteopontin, laminins and thrombospondins [142]. http: //www.ncbi. nlm.nih.gov/pmc/articles/PMC3566109/-pone.0054778Hines1. Moreover, ECM not only provides the structural scaffold for cellular element of BM, but also represents a reservoir of cytokines, chemokines, and growth factors, produced by hematopoietic cells and BMSCs. The interaction between tumor and stroma occurs through the expression of receptors on the surface of leukemic cells binding the stromal cells or through adhesive ligands present both on stromal cell or ECM. Collectively, the BM architecture allows myelopoiesis, lymphopoiesis and immunoregulation processes in close physical proximity [143]. Accumulating evidence suggests that BM niches promote proliferation of a subpopulation of leukemic stem cells (LSCs), enhance their survival, and protect them from chemotherapy. Thus, the BM microenvironment has been proposed as a sanctuary for minimal residual disease, responsible for the occurrence of relapses, in several leukemias, including AML and ALL [144-146]. These events are mediated by the interaction between leukemic tumor cells/LSCs with specific components of ECM, with soluble factors present in the BM microenvironment or BMSCs. The processes of homing, mediated by soluble factors such as SDF-1, and the adhesion to the 
stromal niche, thanks to adhesion molecules like CD44 or VLA4 integrins, are crucial events. The sequestered leukemic cells can proliferate thanks to several growth factors, cytokines, pro-angiogenic factors present in the BM stroma [145]. Interestingly, the adhesion of leukemic cells to the stromal niche elicit a better survival rate. Several mechanisms have been proposed to explain this feature, such as the induction of the cell adhesion-mediated drug resistance phenomenon (CAM-DR) [147, 148], the induction of a reversible quiescent state, that favors cell survival because most standard chemotherapies act on proliferating cells [145] and the increase of hypoxic areas which contributes to chemoresistance of leukemic cells http: //www.ncbi.nlm.nih.gov/pmc/ articles/PMC3414410/ - R10 [149]. The discovery of this complex network, in which the leukemic cells are only one of the participating players, suggests that more effective molecular therapies should target not only leukemic cells but also their microenvironment $[150,151]$. Thus, useful leukemia models should reproduce not only a generic $3 \mathrm{D}$ environment, but also the specific leukemia microenvironment, represented by BMSCs, specific components of ECM or soluble factors embedded.

\subsection{D Leukemia Models}

Relatively few 3D models have been specifically set up for AML and ALL, thus multiple myeloma (MM) and chronic myelogenous myeloid leukemia (CML) and $3 \mathrm{D}$ models have also been considered in this review.

\subsubsection{Leukemia Cell Lines on Scaffolds}

The widely used 3D model of cellular spheroids, formed by spontaneous aggregation of cells, is well suitable for adherent cells but not for leukemia cells, that grow in suspension. Thus, leukemia cells necessarily need a support, such as a scaffold, eventually coated with an ECM component. Blanco and collaborators [152] evaluated the adhesion and the proliferation of several AML cell lines on different polymeric scaffolds, coated with ECM proteins. They showed that the polyurethane (PU) scaffold coated with collagen type I had the best performance, allowing the cell growth for over 6 weeks in the absence of exogenous growth factors. $\mathrm{Vu}$ and collaborators [153] produced an alginate hydrogel able to mimic 3D soft marrow tissue. The addition of the RGD peptide, the integrin-binding motif, to the hydrogel promoted further K562 leukemic cell growth and enhanced cell differentiation.

\subsubsection{Co-Culturing Leukemia Cell Lines and BM Stroma Cells}

Increasing complexity can be achieved by coculturing a leukemia cell line with BM stroma cells. Dainiak and collaborators [154] used, as a scaffold, a polyacrylamide-based macroporous hydrogel $(\mathrm{MH})$, functionalized with the type I collagen and with a structural analogue of the cell adhesive peptide RGD. MHs scaffolds with differently functionalized surfaces have been seeded with the human acute myeloid KG-1 leukemia cell line cultured with human embryonic fibroblast on MHs. The authors found out that leukemia cancer cells formed multicellular aggregates on collagen or RGD-like functionalized $\mathrm{MHs}$ but not on plain $\mathrm{MHs}$ and that KG-1 aggregates were more resistant to the treatment with the chemotherapeutic drug Arabinofuranosyl Cytidine (Ara-C).

The increased resistance to chemotherapeutic agents in a 3D environment, with respect to the corresponding 2D model, is a common feature not only in leukemia cell but also in other tumor types [78]. Moreover, the co-culture system results in a further increase of the chemoresistance. Indeed, Alitawi and collaborators [155] developed and characterized an in vitro 3D co-culture system where leukemia cell lines were seeded with human BM MSCs on a polyglycolic acid/poly-l-lactic acid (PGA/PLLA) copolymer scaffold. The effects of cytotoxic agents, such as doxorubicin or cytarabine, were evaluated and results were compared to those obtained by culturing leukemic cells alone in suspension (2D monoculture), or growing over a monolayer of expanded hu-BM-MSCs (2D co-culture). The authors demonstrated that $2 \mathrm{D}$ and $3 \mathrm{D}$ co-culture conditions showed less cytotoxicity of chemotherapy when compared to the $2 \mathrm{D}$ monoculture condition and that the 3D co-cultures achieved the highest resistance to chemotherapy. Moreover, these authors tested the capacity of free diffusion of molecules with different weights inside the PGA/PLLA scaffold, showing that it allows free diffusion of molecules up to $1000 \mathrm{Da}$ [155]. This is one of the major issues in designing a 3D model for chemotherapy, since the 3D model need to allow media components and cytotoxic agents to diffuse freely to target cells.

An innovative 3D model was set up by Usuludin and coworkers [156]. They developed a hematopoietic coculture system using the hollow fiber bioreactor (HFBR, purchase from FiberCell Systems Inc., Federick, MD, USA). An immortalized human BM stromal cell line, HS-5, was first established and maintained for up to 28 
days in the HFBR. Subsequently, K562 erythroleukemia cells were added to the bioreactor. The HFBR co-cultures enhanced proliferation of leukemic cells, compared to a standard 2D condition. Moreover, in 2D cultures, cells differentiated along the erythrocyte and monocyte pathways, but retained a subpopulation of myeloid progenitors. On the contrary, HFBR cocultures showed multilineage differentiation pathways, such as the megakaryocytic, and the monocytic lineages, while erythroid differentiation was inhibited. Importantly, the cells expanded in the HFBR culture were mostly adherents, emphasizing the importance of cell-cell contact for leukemic cell proliferation.

\subsubsection{D Leukemia Models with Primary Cultures}

A very interesting application for leukemia 3D models is the ex vivo expansion of the leukemic cells isolated by patients. It has been demonstrated that primary leukemia cultures better survive and proliferate in a 3D mimicry with respect to classical 2D techniques $[157,158]$. One of the most important advantages consists of having a sufficient number of neoplastic cells to identify the most effective drugs. Patient specimens that are derived from BM biopsies or peripheral blood often contain too few neoplastic cells in order to test drug effectiveness. Accordingly, 3D ex vivo expansion of primary tumor cells would allow the identification of personalized drugs.

Kirchner and collaborators [157] reconstructed a 3D $\mathrm{BM}$ ambient, by coating BMCs in fibronectin/Matrigel ${ }^{\mathrm{TM}}$ mixture on a collagen I/fibronectin scaffold. In this 3D issue culture model, they succeeded in expanding multiple myeloma (MM) clones isolated by $\mathrm{BM}$ mononuclear cells (BMCs) of aspirates, so that it was possible to test the anti-tumoral efficacy of well-known drugs, such as Melphalan and Bortezomib. Intriguingly, Hou and coworkers [158] have succeeded in reproducing a 'biomimetic osteoblast niche' with bioderived bone as a scaffold, coated with osteoblasts obtained by differentiating MSCs of CML patients. The reconstructed osteoblast niche maintained stem/ progenitor cells from BM of patients CML for a long period of culture, more efficiently than the $2 \mathrm{D}$ culture system.

\subsubsection{Ex vivo Maintenance of $B M$ Biopsies in Bioreactors}

Up to date, Ferrarini and collaborators set up the first 3D dynamic culture system for BM biopsies derived from patients with hematological tumors. The authors used the Rotary Cell Culture System $\left(\operatorname{RCCS}^{\mathrm{TM}}\right)$
Bioreactor, a device specifically designed to culture cells in a $3 \mathrm{D}$ milieu in microgravity. The $\mathrm{RCCS}^{\mathrm{TM}}$ was applied to ex vivo cultures of MM specimens [134], obtaining long-term cultures of myeloma tissue explants. Stained histological slices showed a preserved architecture in which viable MM cells were embedded in their native microenvironment, comprehensive of the lamellar bone and vessels. The ex vivo cultures of MM specimens in the RCCS ${ }^{\mathrm{TM}}$ bioreactor were also used to test the antitumoral efficacy of the proteasome inhibitor Bortezomib, a well-known drug used in MM therapy. Remarkably, the beta2microglobulin levels, a proliferative marker commonly used for staging of MM, in patients' sera before and after the drug therapy paralleled those observed in supernatants from the ex vivo cultures in presence/ absence of Bortezomib. Thus, these results showed an interesting concordance between the effects exerted by Bortezomib in vivo and ex vivo. Collectively, the results obtained on ex vivo cultures, showed that it was possible to maintain the original tissue architecture and the specific microenvironment for each patient, potentially allowing the maximum degree of predictability in drug response.

\subsubsection{D Microfluidic Tissue Models}

At the intersection of tissue engineering and microfluidics recent advances show that it is possible to grow in vitro 3D tissues by reproducing the nutrient and waste transport function of the microcirculation and the emulation of the shear stress effects. One of the most important advantages is also the use of very small amounts of reagents and cells and the real-time monitoring of cellular parameters. Several microfluidic devices have also been set up to emulate tumor growth in the BM microenvironment.

Zhang and collaborators [159] have seeded the microfluidic culture chambers with a human osteoblastic cell line. This cell line easily adhered to the support and produced a measurable extracellular matrix (ECM), thus mimicking a tumor osteoblastic niche, which then facilitated the seeding of mononuclear cells from BM biopsy of MM patients. Real-time monitoring microscopy and flow cytometry post-analysis showed that this in vitro MM tissue model permitted the preservation and proliferation of primary human MM cells. Moreover, it recapitulated the essential interactions between malignant cells and the recreated endosteal niche, all within a perfused microenvironment intended to mimic the fluidic features of the BM. The relevant clinical advantage, proposed by 
the authors, is the requiring of very small amounts of patient-derived BM cells $\left(<1.10^{6}\right.$ cells, for an eightchamber microfluidic device), allowing an accelerated evaluation of new therapeutics for the personalized treatment of multiple myeloma.

Opposite to this dynamic microfluidic system, Khin and collaborators [160] have very recently set up a static 3D microfluidic device, allowing a co-culture of $\mathrm{MM}$ cell lines with the adherent BM-derived stromal cell line HS-5 or a co-culture of MM primary cells with patient mesenchymal cells. Static microfluidic devices do not allow the mimicking of the fluidic flow, however they avoid the possible generation of several artifacts, caused by the continuous flow (e.g. removal of soluble signals important for cell-cell communication, unvaried concentration of media components) typical of dynamic systems [161]. MM and stromal cells were mixed into the collagen/media mix and seeded in commercially available 3D cell-culture slides ( $\mathrm{m}$-slide Chemotaxis $3 \mathrm{D}$ Ibitreat from Ibidi, LLC). 3D co-cultured cells were exposed to Melphalan and Bortezomib, in order to set up a preclinical assay for chemosensitivity. Digital images obtained with live microscopy were analyzed to detect cell death after drug exposure. Using this platform, the authors were able to predict the chemosensitivity to Melphalan and Bortezomib in several MM patients [160].

\subsubsection{D Leukemia Models for Testing Motility/ Invasion}

Infiltration of leukemia cells in several organs is a common feature of the disease. Specific assays for testing motility and invasion in the 3D milieu can be of interest. In cancer research, the most popular cellular invasion assay is the Transwell (or Boyden) chamber assay. Cancer cells are seeded on top of a thin gel containing ECM molecules, in turn positioned above a filter. The invasion capability is evaluated by counting the number of cells able to pass to the other side of the filter [162]. This assay is very appealing because of its speed and the ease in the quantitative analysis. However, the biological process is conducted in a limiting 2D milieu and only the end point is monitored. To overcome these problems the $2 \mathrm{D}$ well-known transwell assay has been adapted in order to study migration in 3D matrix. In 3D motility assay, cells are embedded within a thick matrix of seeded on top (collagen or Matrigel ${ }^{\mathrm{TM}}$ ). Results are obtained by counting the number of migrating cells in the ECM gel [163]. Several authors have used the transwell chamber assay in 3D matrix for testing invasion ability of leukemia cells $[164,165]$. This method was later refined, by observing leukemia cell motility in 3D Transwell with time-lapse microscopy. The image analysis allowed not only quantifying cell motility in the samples, but also to describe the type of motility, i.e. amoeboid or rolling type [166].

A similar and simplified method with respect to the 3D Transwell assay consists of applying collagen or Matrigel $^{\mathrm{TM}}$, containing specific chemoattractants to be studied, directly into the cell culture plate and adding cell leukemia suspension on top. Cellular invasion was scored by evaluating the number of cells at different positions in the 3D matrices, by using an inverted microscope and a digital depth meter [167, 168]. A more complex 3D model for testing cell motility was developed by de Silva and collaborators [169], where they have fabricated an Inverted Colloidal Crystals (ICC) scaffold, with a 3D honeycomb-like structure from colloidal crystal templates. The internal dimensions of hydrogel-made pores, as well as the gel stiffness, were tuneable, thus rendering these ICC scaffolds suitable for cell invasion studies. The authors tested the migration ability of the acute promyelocytic leukemia NB4 cell line, which can differentiate with all-trans retinoic acid (ATRA) into mature, highly mobile neutrophils [170]. Fluorescent marked NB4 cells were seeded on the ICC scaffolds and the invasiveness was calculated by analyzing confocal images at different depths. The authors succeeded in clearly demonstrating the ability of differentiated NB4 to enter the scaffold, while non-differentiated cells were only very occasionally found below the scaffold surface [169].

\subsubsection{D Models for Expanding Normal HSC, a Tool for Clinical Therapy}

Several 3D models have been developed in order to mimic normal BM niches [171-173]. Artificial analogues of BM can accelerate the understanding of hematopoiesis in humans or can be suitable for ex vivo simulation of some aspects of human immune response. Moreover, in the oncological field, these 3D models can be useful for in vitro production of human hematopoietic cells. Indeed, the HSCs transplantation, a widely used therapy for several hematological malignancies, presents two important limitations: an insufficient number of matching donors and the difficulty of obtaining enough cells [174]. Thus, expanding HSCs, obtained from donors, can be a suitable strategy to overcome these obstacles. 


\section{LYMPHOMA}

Lymphomas represent the third most common childhood malignancies. In under 15-year-olds they occur at a median age of 10 years and 8 months; nonHodgkin lymphoma-NHL (including Burkitt lymphoma) $(6.6 \%)$ and Hodgkin lymphoma-HL $(4.8 \%)$ are the most frequent diagnoses in this age group. The same pattern is seen in adolescents and young adults. Lymphomas, especially $\mathrm{HL}$, are practically non-existent among young children [12]. More than $90 \%$ of pediatric NHLs are high grade lymphomas divided into four major histologic subtypes: diffuse large B-cell lymphoma, Burkitt lymphoma, lymphoblastic lymphoma and anaplastic large cell lymphoma.

The two most common $\mathrm{HL}$ in children are the nodular sclerosis $\mathrm{HL}$ and the mixed cellularity $\mathrm{HL}$. Lymphomas start generally in lymph nodes and diffuse through the lymphatic vessels to other lymph nodes or to the spleen, or to extranodal area, such as bone, BM, liver and lungs. Other lymphomas, in particular NHL, arise outside the lymph system, especially in the digestive tract (stomach, intestines, liver), thyroid gland or skin.

\subsection{Lymphoma Microenvironments}

With respect to solid tumor, dealing with lymphoma cancers is more complicate, since they can proliferate both in suspension and in several tissues [175]. As demonstrated in other tumors, the progression of lymphomas involves a complex interactions between neoplastic cells and their microenvironment, including the tumor's vascular system and the stromal cells. Due to the complexity of lymphoma malignancies, residing in different tissues, the microenvironment is characterized by different populations. In BM, lymphoma cells are interacting with the BMSCs, already discussed in the leukemia paragraph. In secondary lymphoid organs, these non-malignant stromal cells consist of a heterogeneous group of cells, such as macrophages, follicular dendritic cells, follicular reticular cells, fibroblasts, B small lymphocytes, plasma cells, Th1 and Th2 cells, T regulatory cells (T-regs), eosinophils, mast cells and granulocytes. They are recruited and/or induced to proliferate by tumor cells and produce soluble or membrane-bound molecules involved in tumor cell growth and survival. The tumor-host communication is a complex network, involving adhesion molecules, chemokines, and chemokine receptors. The resulting tumor growth depends on the balance between the inhibitory and growth-promoting signals [176, 177]. Thus, in each tissue, lymphoma cells presents an unique network of signals, and therefore is hard to get targeted therapies $[175,178]$.

\subsection{D Lymphoma Models}

The literature on 3D lymphoma models is very poor. This gap can be partially filled by considering that most of the 3D leukemia models are also suitable for lymphomas. However, to the best of our knowledge, the $3 \mathrm{D}$ reconstruction of the lymphoma microenvironment, at least in lymph nodes, is completely missing. Much work remains to be done in this area.

\subsubsection{Scaffold-Free Lymphoma 3D Models}

As leukemic cells, lymphoma cells can not form cellular spheroids, typical of adherent cells. However, a method was recently proposed of forming 3D multicellular aggregates (MALC) of lymphoma cells [179] in vitro, by modifying the well-known hanging drop technique [180]. The $t(14,18)+$ follicular lymphoma $\mathrm{RL}$ cell line was used for this purpose and the growing cells formed compact oval-shaped aggregates, with $\sim 1$ $\mathrm{mm}$ diameter, a dimension never reached with the standard 2D culture [179]. The gene expression profiles either from RL 2D cell suspension or from $R L$ cells grown as MALC were analysed. Cells from MALC presented more anti-apoptotic gene expression profiles, and they were more resistant to $N K$-mediated lysis than cells in 2D culture, suggesting an innate predisposition to immune escape [179]. Later, MALC of $\mathrm{RL}$ cell lines were used, by the same authors, to test the anti-tumoral activity of obinutuzumab and rituximab, two antibodies recently proposed in lymphoma therapy [181]. As already demonstrated in several tumor types, the cells grown in a $3 D$ model showed different drug responses than those grown in $2 D$, highlighting the importance of developing 3D models for the testing of chemotherapeutic drugs, not only in $\mathrm{NHL}$, but also in all type of cancers.

\subsubsection{Lymphoma Cell Lines on 3D Scaffolds}

Birgersdotter and collaborators [182] developed a 3D model of $\mathrm{HL}$ by using a cell culture matrix based on an oligopeptide, which has been extensively tested for 3D mammalian cell culture [183, 184]. This oligopeptide consists of regular repeats of alternating ionic hydrophilic and hydrophobic amino acids (arginine, aspartic acid and alanine), and associates to form stable beta-sheet structures in water. The presence of monovalent cations results in the spontaneous assembly of the oligopeptide into a stable, macroscopic membranous matrix, composed of ordered filaments 
that form porous enclosures. The authors cultured the $\mathrm{HL}$ cell line L1236 in the 3D oligopeptide and its gene expression profile was analyzed, in parallel with $2 \mathrm{D}$ culture condition and with fresh lymph node biopsies from HL patients. The authors found that the 3D culture modulated gene expression of the L1236 cell line, better mimicking the in vivo expression profile [182].

\subsubsection{Co-Cultures of Lymphoma and Stromal Cell Lines on 3D Scaffold}

Caicedo-Carvajal and coworkers [175] have developed a 3D cell co-culture system in order to optimize the growth of mantle cell lymphoma (MCL) cell lines. The scaffold was made of four layers of polystyrene (PS), a geometry generating a characteristic 3D porous structure. 3D PS Scaffold was seeded with a MCL cell line: HBL2, of lymph node origin. HBL2 cells were cocultured with human dermal fibroblasts (hDFb) in the 3D milieu, showing and enhanced cell proliferation, with respect to the $2 \mathrm{D}$ culture. The authors suggest that this 3D system allows the expansion of primary tumor cells of patients, from blood or other tissues in which hematological cancer cells are present, and that these expanded cells can be used for customized drug screening assays.

\section{CNS PEDIATRIC TUMORS}

The heterogeneous group of pediatric CNS tumors are the most common solid cancer in the pediatric age and the second most common tumor after leukemias, representing 20 to $25 \%$ of all childhood cancers [12]. Pediatric CNS cancers comprise a diverse group of tumors with different histology, arising at various sites within the central nervous system. The largest subgroups are astrocytomas ( $43 \%$ of all brain and CNS tumors in children), which are diagnosed throughout childhood. Most of the astrocytomas are diagnosed as low-grade (grade I: juvenile pilocytic astrocytomas, grade II: diffuse astrocytomas), while a small percentage as high-grade (grade III: anaplastic astrocytomas and grade IV: glioblastoma multiforme). The second most common group is represented by the embryonal tumors (19\% of all childhood brain and CNS tumors). Most of these are medulloblastomas and cerebral primitive neuroectodermal tumors (PNET). Finally, about $10 \%$ of childhood brain and CNS tumors are ependymomas and choroid plexus tumors $[12,185]$.

\subsection{CNS Pediatric Tumor Microenvironment}

High-grade brain tumors display striking cellular heterogeneity. Some of the cells show increased tumorigenicity and stem-cell-like capacity, and they have been proposed as the cells of origin for tumor recurrence. Thus, the existence of cancer stem cells (CSCs) has been demonstrated in several high-grade CNS tumors, such as glioblastomas, ependymomas and medulloblastomas, even if the CSCs presence in lower grade tumor is controversial $[186,187]$. However, also in CSN cancer, the tumor-associated parenchymal cells, such as endothelial cells, microglia, immune cells and neural precursor cells, also play an important role in the evolution of the disease.

Resident activated microglia or new recruited macrophages from blood, are the most abundant nontransformed cells present in brain tumors. It has been shown that the M1 phenotype, with anti-tumoral properties, is the most prevalent in low-grade CNS tumors, while the M2 phenotype, also designed as Tumor Associated Macrophages (TAMs) positively correlates with the histological malignancy of the tumor $[188,189]$. It has been demonstrated that TAMs promote glioma cell proliferation, as well as angiogenesis and invasion [190, 191].

CD8 and CD4 $\mathrm{T}$ cells are also present in brain tumors. Some authors identified the CD8/CD4 T cell ratio as prognostic factors, as demonstrated in non CNS tumor. Indeed, in colon cancer it has been demonstrated that the CD8/CD4 ratio is higher in patients with better clinical outcomes [192]. Consistent with these findings, it has been shown that pilocytic astrocytomas showed the highest CD8/CD4 ratio and that the average ratio of CD8/CD4 in ependymomas, multiforme glioblastomas, medulloblastomas was progressively lower [188]. However, the correlation between lymphocyte infiltration and clinical outcome is still controversial.

More recently, the focus is shifting on the regulatory $T$ cells (Tregs), identified by the antigen FoxP3, with pro-tumoral activities. For instance, it was shown that FoxP3 expression correlates with the tumoral progression in several types of astrocytomas [193], and that temozolomide, the standard chemotherapeutic agent for glioblastoma, induced a reduction of Tregs, both in the blood and in the tumor tissues [194]. Therefore, Tregs have been identified as a novel targets in glioma treatment.

Recently it has been demonstrated that glioblastomas can interact with normal neural precursor cells (NPCs). Interestingly, NPCs are recruited from brain tumor tissue, thanks to chemoattractant 
molecules, such as CXCR4, and their number inversely correlates with tumor-size and survival. Thus, an antitumorigenic action for NCPs has been postulated. In vitro experiments seem to sustain this hypothesis, since cultured NPCs release soluble factors that can inhibit glioblastoma proliferation, induce differentiation and cell death [189]. Brain tumors are highly vascularised and this rich vascular network is not only a matter of tissue oxygenation, but, more importantly, of endothelial cells, pericyte, and astrocyte (the neurovascular system) presence, that support tumor progression. This microanatomical structure, designed as perivascular niche (PVN), contain stem cells in both normal and brain tumoral tissues. This complex network of cells allows multiple interactions, promoting CSCs proliferation, enhancing their survival, and protecting them from chemotherapy [187, 189].

Together with the perivascular niche, it has also been postulated the presence of the hypoxic niche [186], as already observed in leukemia and other tumors. Hypoxia promotes the acquisition of stem-like properties, can facilitate the CSCs maintenance, and promotes neoangiogenesis [186, 187]. Of note, we must not forget the role of ECM in the pathogenesis of brain tumoral disease. For instance, it has been demonstrated that proteoglycan expression is altered in human glioblastoma and that this modification promotes an abnormal activation of the receptor tyrosine kinase (RTK), involved in the progression of the disease [195].

\subsection{D Models For CNS Pediatric Tumors}

\subsubsection{Tumor Brain Spheroids or Neurospheres}

Spheroids of brain tumor cells (neurospheres) have been largely employed by scientists for at least three decades. Both stabilized brain cancer cell lines and primary cells, obtained from biopsy of CSN tumors, can be used to form spheroids [196]. As frequently happens in the 3D world, neurospheres are more representative of the tumor with respect to the corresponding monolayer cultures. For instance, it has been demonstrated that genomic profiles of primary cells of glioblastomas, cultured in 2D stardard condition, very often deviate from the parental cancer profiles, whereas genomic profiles are generally preserved in sheroids [197]. As with other types of solid tumors, neurospheres are also widely used for tumor biology or drug screening studies, being suitable for tests on proliferation, cell death, invasion and motility [198]. After the discovery of neural stem cells [199], research on neurospheres has undergone a major impetus. Indeed, neurosphere cultures have shown to be a suitable method to isolate and propagate neural stem cells. The neurosphere assay, developed with the aim of confirming that neurospheres contain neural stem cells, was initially proposed by Reynolds and Weiss in 1992 [200]. They were able to culture primary cells isolated from the normal striatum tissue of the adult mouse brain, in the presence of epidermal growth factor. At the beginning of the culture, most of the cells had died, but few cells survived, proliferated and formed a free-floating 3D spherical cluster of detached cells, the neurospheres. The proliferating cells initially expressed characteristic markers of stem cells, such as nestin. Moreover, the neurospheres continued to proliferate in secondary cultures, after their mechanical dissociation and plating as single cells. Interestingly, after several days of culture, the secondary neurospheres were able to differentiate into astrocytes, neurons and oligodendrocytes with phenotypes characteristic of the adult striatum in vivo [200, 201]. In the following years, scientists have demonstrated the presence of neural stem cells in several regions of embryonic and adult brains both in human and mouse [201]. The neurosphere assay is now a widely used technique suitable to isolate neural stem cells; it permits to examine the three fundamental characteristics of neural stem cells: proliferation, self-renewal, and multipotency [201]. Later, neurospheres containing stem-like neural precursors were also obtained from human glioblastoma multiforme specimens by Galli and collaborators [202]. The authors demonstrated the ability to proliferate, to undergo self-renewal and to generate neurons, astrocytes, and oligodendrocytes, as the normal neuronal stem cells do. Moreover, these cells injected orthotopically in immunocompromised mice can form cancers with a histological architecture similar to that of the human tumor [202]. In subsequent years, scientists have succeeded in obtaining neurospheres containing cancer stem cells from ependymomas, medulloblastomas, and primitive neuroectodermal tumors and from high grade gliomas (grade III anaplastic astrocytomas and grade IV glioblastomas) but not from lower grade gliomas [203206]. Detailed protocols for obtaining them are now available in the literature [200, 204, 207-209]. Thus, the neurosphere cultures have represented a suitable 3D model for deepening understanding of the role of brain tumor stem cells in radio- and chemoresistance mechanisms, as well as in the brain tumor response to growth factors, hypoxia, and pharmacological agents [210-214]. The possibility of performing gene/protein 
expression analysis as well as to section neurospheres for histology or immunocytochemistry allows detailed molecular studies. Moreover, the isolation and propagation of neuronal stem cells from a specific specimen allows studying patient-specific pharmacologic approaches.

\subsubsection{Co-Culturing Neurospheres and Immune Cells}

Co-culturing approaches with neurospheres and immune cells, normal constituents of the tumor microenvironment, are also of particular interest. Iwasaki and collaborators studied the infiltrative capacity and the cytolytic process of lymphokineactivated killer (LAK) cells against a human glioma spheroid model. Multicellular tumor spheroids were cocultured with LAK cells on a rotary shaker. Histological analysis revealed that LAK cells are able to infiltrate directly in the core of the spheroids, causing tumor cytolysis [215].

Kees and collaborators have studied the role of microglia, isolated from patients with glioma, in the control of proliferation and invasion of spheroids derived from glioblastoma cell lines. They have used a collagen co-culture model, seeding both glioma spheroids and microglia cells. They demonstrated that human microglia has tumor-promoting activities that are overridden by pharmacological treatments [216].

More interestingly, the pro-tumoral effects of the altered microglia from brain tumor patients on brain tumor initiating cells (BTICs), a subpopulation expressing stem cell markers, can be reversed after the treatment with Amphotericin B (AmpB). Indeed, cultures of monocytes and microglia from glioma patients were not able in inhibiting the spheres formation of autologous BTICs, but this was modified by AmpB treatment [217].

In a recent paper, Etminan and co-worker have cocultured glioma spheroids with dendritic cells (DCs), with the aim of testing the antitumoral efficacy of the photodynamic therapy. Indeed, after the treatment, immature DCs were recruited into the glioma spheroids. They then matured, likely activating specific T cells with anti-tumoral activity [218].

\subsubsection{D Co-Cultures of Tumoral CNS Cells and Normal Brain Cells}

3D co-cultures of normal brain cells and glioblastoma-derived cells have been set up by Biggs and coworkers [219]. Normal brain cells were isolated from cortices of Wistar rats and allowed to reaggregate and to mature for 20 days, by placing them on a semi-porous membrane at an air-liquid interface, and subsequently generating characteristic brain $\mathrm{Hi}-$ Spots [220, 221]. Histological analysis showed that both neurons and astrocytes were present in these 3D cultures, with a preserved physiological architecture. On this reconstructed 3D neural tissue, fluorescent marked glioblastoma cells were seeded. The authors could observe their spread throughout the Hi-Spots, forming new cell aggregates, and able to last for many days $(25 \mathrm{~d})$ in culture. This platform was then tested for evaluating anticancer compounds, thus representing a simple system to verify drug effectiveness on brain tumors in an orthotopic environment [219].

Orthotopic 3D co-cultures of tumor brain spheroids in normal brain tissues have been also set up to test invasiveness. In this case neurospheres have been implanted on the center of human [133] or rat brain slices [222]. The histological evaluation of the confrontation revealed either an invasive pattern or a non-invasive pattern (see the relevant paragraph for a better description).

\subsubsection{D Tumoral CNS Cultures on Scaffolds}

One of the earlier research studies on 3D culture of brain tumor cells was presented in 1977 by Carllson [223]. He studied the mitotic activity of glioma cells embedded in an agarose gel, in relation to the position of the cells in the colony, finding that the fraction of cells that incorporated tritiated thymidine decreased nearly exponentially with the depth in the colonies [223]. Over time, it has become increasingly clear that matrices in which cells are embedded is not simply a scaffold to hold them on, but a it is communicating structure important in determining cell function and behaviour [224].

Thus, scientists have tried to mimic specific components of the brain ECM, in order to better reproduce the microenvironment. Many compositions of the matrix have been studied. One of the widely used constituents is the collagen [225-227], eventually mixed with other molecules, such as agarose [228], the ECM proteins tenascin [229] or chondroitin sulfate [230]. Among the ECM components, an important role has been demonstrated for $\mathrm{HA}$, able to regulate the glioma cell phenotype [231] or to increase stem-like properties of glioblastoma cells [232]. For this reason, hydrogels containing HA have been proposed as a scaffold for neuronal tumors [233]. 
In the recent years, scientists have set up HA-based scaffolds in combination with other molecules, such as a different type of collagens [230, 234], the kappaelastin (HA-KE), present in the basement membrane of blood vessels [235], gelatine, PEG [231], and chitosan [232]. Besides these natural extracellular matrix materials, which are expensive and potentially could transmit pathogens [236], several natural polymers have been also studied, such as chitosan-alginate scaffold [125], or alginate hydrogel functionalized with D- or L-aminoacids [237]. Thus, thanks to these experimental models it was possible to study the impact of the individual components of the ECM on tumor biology [230-232] and to assess pre-clinical drug and radiation sensitivity screening [238, 239].

\subsubsection{D Models for Testing Motility/lnvasion of CNS Tumors}

Gliomas are highly infiltrative tumors, thus several 3D culture methods have been set up in order to study this parameter. The widely used $3 \mathrm{D}$ transwell or spheroid invasion/motility assays in soft matrices, like collagen, Matrigel ${ }^{\mathrm{TM}}$, fibronectin or agar are extensively applied in brain tumor research [225, 226, 240-244]. Moreover, several other matrix compositions have been tested with the aim of better reproducing the in vivo microenvironment. Thus, invasion assays have been performed in HA-based hydrogel [230, 233-235].

An intense interstitial fluid flow is present in gliomas, during the processes of angiogenesis, and invasion. Therefore, the impact of the interstitial fluid flow on glioma cell invasion can be of interest. With this purpose, modifications of the classical 3D transwell invasion assay have been presented recently [245]. Glioma cells, with different invasive properties (noninvasive and invasive) were seeded in a gel containing $\mathrm{HA}$ or collagen $\mathrm{I}$ and placed on porous membrane, like a classical transwell assay. The above setup was modified, by establishing, in the casted gel containing the seeded glioma cells, a fluidic flow with an average speed of $0.7 \mu \mathrm{m} / \mathrm{s}$ through the cell/gel compartment, mimicking the interstitial fluidic flow. Interestingly, the authors showed that the interstitial flow promotes cell invasion in several glioma cell lines and that the flow effect was dependent on the CXCR4 receptor, involved in brain cancer invasion and progression [246].

Invasion assays with spheroid co-cultures (confrontation assays) has also been developed. In this case, neurospheres are placed in contact with normal tissues, which are used as the target tissues that may be invaded and destroyed by invading neoplastic cells [247]. Either embryonic chick tissue, foetal brain aggregate (heterologous), or normal connective tissue from the tumor-bearing patient (autologous) [240, 242, 248-251] have been used as the target tissues.

After adhesion of the tumor cells to the normal tissue, histological evaluation of the confrontation will reveal either an invasive pattern or a non-invasive pattern. In the invasive pattern, the tumor-derived cells invade into the host tissue and replace it, as it is often seen with high grade gliomas [252, 253]. In the noninvasive pattern the tumor-derived cells live together with, and generally surround the host tissue without replacing or destroying it, as seen with non-invasive benign meningioma [253, 254]. Several upgraded protocols have been proposed, which consist in implanting fluorescent stained spheroids, obtained from human brain tumors, on the center of human [133], or rat brain slices [222]. The invasion process can be evaluated over the time by using a confocal microscopy. The advantages consist in a better representation of the invasion process, due to the fluorescent tag applied to the tumor cells, as well as in a better representation of extracellular matrix molecules normally encountered by invading glioma cells [133, 222]. Oellers and collaborators described a similar refined protocol [255], presenting a co-culture of glioma cells with myelinated axons in vitro, with the aim to study the interactions between migrating glioma cells and nerve fibers. Glioma cells were positioned close to the long retinal axons obtained derived from explants of embryonic chickens. Migration of cancer cells has been monitored by confocal microscopy and high-resolution video microscopy [255]. Overall, the invasiveness results obtained by confrontation assay are correlated with malignancy in vivo [256]. Moreover, this assay is also suitable for study of the involvement of specific genes, for testing various anti-tumoral molecules/drugs or the effect of radiotherapy on brain tumor invasion ability $[250,257,258]$.

Besides these classical assays, scientists have also proposed particular protocols to measure motility and migration in brain tumors. For instance, Agudelo-Gracia and collaborators have studied motility of glioma cells cultured on nanofiber scaffolds, that mimic the neural topography [259]. Neurospheres obtained form glioblastoma cell lines or tumor explants were manually placed within nanofiber-coated wells to analyze the migration, by analyzing the total area and perimeter 
covered by the migratory cells. The authors found that cell migration of glioblastoma neurospheres was reduced by STAT3 inhibitors. Notably, these inhibitors at the same concentrations failed to inhibit migration in a standard 2D system [259].

\subsubsection{Bioreactors}

One of the first experiments on brain tumor cells 3D growing in a bioreactor was presented by Ingram and collaborators [260]. Several malignant glioma cell lines were introduced in the NASA rotary cell culture system, forming spheroids with an increasing expression of the adhesion molecule CD44 over the time in culture [260]. An exhaustive study on brain tumor aggregates generated using the $3 D \mathrm{RCCS}^{\mathrm{TM}}$ has been presented recently by Smith and collaborators [261]. Several types of brain cancer cell lines (pediatric glioblastomas and high grade gliomas, pediatric central nervous system primitive neuroectodermal tumor, pediatric medulloblastomas) were grown in conventional 2D cultures and the RCCS ${ }^{\mathrm{TM}}$. Gene expression and microRNA profiles were analyzed, as well as drug sensitivity to Vorinostat, a histone deacetylase inhibitor. The principal finding was that $3 \mathrm{D}$ culture in $\mathrm{RCCS}^{\mathrm{TM}}$ better recapitulates the histological architecture and the molecular profiles of primary brain tumors with respect to 2D cell culture. Similar findings were also obtained with primary explant culture in the $\mathrm{RCCS}^{\mathrm{TM}}$, which retains features of the primary brain tumor. Moreover, the 3D glioblastoma aggregated of the RCCS ${ }^{\mathrm{TM}}$ cultures demonstrated a reduced sensitivity to Vorinostat with respect to the $2 \mathrm{D}$ system, and likely better recapitulate the drug response observed in vivo [261].

Panchalingam and coworkers [262] developed bioreactor protocols for expanding cancer stem cells from human glioblastoma specimens. Human glioblastoma-derived cells were introduced in a bioreactor with paddle impellers (NDS Technologies, Palo Alto, CA). The expanded cells were characterized using both flow cytometry and a differentiation assay. The obtained results showed that a high percentage of the expanded tumor cells possessed stem cell features and that the expression profile was preserved with respect to the brain cancer tissue of origin.

Of note, glioma rat cells have been expanded in hollow-fiber bioreactors. However this model system was not set up for brain cancer studies but for monitoring the cellular effect during ischemia.

\subsubsection{Microfluidic System}

In the literature, there are very few examples of studies carried out in microfluidic on 3D brain tumors. One of the few studies was presented by Lee and collaborators [264], which studied glioma cell migration in soft matrices. As in the static cell growth conditions, the choice of the matrix is also a crucial point for getting the best biomimetic microenvironment in this device. These authors have used a HA hydrogel to seed the glioma cell line A-172. The HA hydrogel can be remodelled by MMPs secreted by glioma cells during migration, and the authors have studied the concentration gradient effect of VEGF in this parameter. The authors observed an intense spreading of glioma cells in the microchannel containing VEGF; moreover these cells were more able to degrade MMPsensitive hydrogel with respect to control cells [264].

A second type of study in microfluidics, which preserves the 3D cell structure, are those dealing with brain slices. The microfluidic technology seems to better preserve the viability of the explanted tissues for some days, by improving the oxygen/nutrient penetration into slices. Therefore, this device can be of interest for developing personalized cancer therapies $[265,266]$.

An interesting microfluidic experimental model was proposed by $\mathrm{Ma}$ and collaborators [267]. They tested the cytotoxicity of two anticancer drugs, temozolomide (TMZ) and ifosfamide (IFO), on glioblastoma multiforme brain cancer cells in conjunction with liver metabolism. The microfluidic devices contained two separate chambers connected in tandem, one for seeding liver cells with different cytochrome P450 (CYP) subtypes and the second for seeding tumor brain cells. Both chambers contained polylactic acid (PLA) as a scaffold, to allow the 3D culture. TMZ, which is inactivated by liver metabolism, was more ineffective in the presence of 3D liver cultures. Conversely, ifosfamide (IFO), which requires CYPdependent activation for its antitumor activity, showed the maximum cytotoxicity in the presence of CYP overexpressing liver cells. Thus, this model could better predict drug effects, by considering the contribution of liver metabolism on drug activities [267].

The limited production on microfluidic devices applied to 3D cellular models might suggest, on one hand, that there are technical difficulties occurring, and, on the other hand, that scientists may prefer different 
3D models. Indeed, 3D models permit the culture of a higher number of cells, and they are not subject to potential biological artifacts, due to mechanical stress for the high hydrodynamic shear forces [268].

\subsubsection{Brain Tumor Explants of Surgical Specimens}

The cultivation of tumor explants allows the maximum preservation of the microenvironment and in personalizing the culture. Of course, they have limited survival time and scientists are committed to finding new protocols to lengthen this time. Some tissues are more suitable, such as lung and colon [269], unfortunately, ex vivo cultures of brain tumor tissues are more difficult to obtain, because of their friability. Tumor blocks transferred in culture medium can be maintained up to 48 hours with preserved histoarchitecture of glioblastoma. In contrast, starting from 72 hours, tumor tissues present cells in apoptosis [270]. Few attempts have been made to lengthen the time of vitality in culture of brain tumor explants, such as those performed in microfluidic devices or in bioreactors (see the relevant paragraphs).

\section{NEUROBLASTOMA}

Neuroblastoma (NBL) is the most frequent extracranial solid tumor of childhood, occurring in very young children, as the median age at diagnosis is 17 months [271]. NBL present a large number of clinical manifestations that range from spontaneous regression to very aggressive malignant growth, so that NBL disease is classified into low-, intermediate-, or highrisk categories, based upon clinical and biological features. The accurate stage of patients at diagnosis and the classification on risk groups is important to tailor the therapy, in order to reduce toxicity and improve outcomes. NBL accounts for about $7 \%$ all childhood neoplasms, but it is responsible for $10 \%$ for the deaths from pediatric malignant diseases [272].

One of the most important prognostic factors is age, with an inverse relationship between age and outcome. Other prognostic factors are the presence of metastasis and some genetic factors of the tumor as MYCN amplification, $11 \mathrm{q}$ deletion and structural aberrations [271, 272]. Tyrosine kinases -TRK family of neurotrophin receptors greatly correlates with clinical outcomes: TrkA expression is associated with a favorable clinical behavior, whereas TrkB with unfavourable outcome [273]. For babies aged younger than 18 months without the amplification of MYCN, even those with metastases, prognosis is better than for older children [271].
Neuroblastomas originate from primordial neural crest cells, thus tumors occur mostly in the adrenal medulla and the rest arise anywhere along the chain of the sympathetic nervous system. They can present as mass lesions in the chest, neck, pelvis or abdomen. Almost $50 \%$ of the patients have metastatic disease at diagnosis, especially in liver, skin, lung, BM and bone [271]

\subsection{Neuroblastoma Microenvironment}

The tumor microenvironment strongly contributes to the evolution of NBL disease. One of the most explored components of the NBL microenvironment is the immune system. It is well-known that high risk NBL can escape the immune system [274]. Several mechanisms have been proposed, such as the downregulation of the human leukocyte antigen (HLA) or adhesion molecule expression on the surface of NBL cells, and the expression of chemokines by tumor cells or infiltrating stromal cells that can down-modulate immune responses or recruit macrophages to disable these lymphocytes [275].

Targeting immune cells, modulating surface molecules involved in the immuno-response, interfering with the cytokine activities, all are promising therapies in fighting this disease [275-277]. Other studies have pointed out the importance of hypoxia level in the progression of the disease. Indeed, it has been demonstrated that the adaptation to low tension of oxygen induces the expression of several genes (the 'hypoxia gene signature'), which allows the cells to survive. Moreover, during hypoxia, NBL cells are more resistant to apoptosis, leading to pleiotropic drugresistance $[278,279]$

Profiling several tumor specimens of neuroblastoma patients, Fardin and coworkers [280] have found that the hypoxia gene signature is associated with most aggressive subtypes, without regard to the MYCN amplification. These authors have proposed that the hypoxia gene signature can be a new potential prognostic factor for neuroblastoma.

The angiogenic switch, intimately correlated with the hypoxic condition [281], is also involved in NBL progression. Indeed, it has been demonstrated that several angiogenic factors, such as VEGF, are expressed in NBL tissues in vivo; moreover, a positive correlation was observed between VEGF expression and poor outcome [282] 
Relapse and metastases constitute the major challenges in clinical management of NBL. Tumor cells disseminating from primary sites to various organ sites have several possible fates: death, progression toward metastasis or formation of dormant micrometastasis. Dormant micrometastasis could progress to an actively growing macrometastatic lesion and cause a late metastatic relapse in the high risk group of NBL patients [283]. Thus, specific microenvironment factors involved in the progression of micrometastasis or in the attraction of human neuroblastoma cells in the site of metastasis have been studied in several organs, such as lung [284], bone [285, 286] or BM [287].

\subsection{D Models for Neuroblastoma}

\subsubsection{Neuroblastoma Spheroids}

The NBL spheroids have been used for more than two decades. As demonstrated in other types of tumors, NBL spheroids better recapitulate the salient aspects of in vivo neoplasm growth [288, 289]. For instance, Kumar and coworkers [288] have studied the different protein expression profile when NBL cells are cultured in 2D with respect to 3D. The proteomic analysis was performed by $2 D$ gel electrophoresis and followed by mass spectrometry identification. Several polypeptides involved in metabolism, cell structure, cell stress response, signal transduction and transport were over-expressed in NBL spheroids. The differential proteins identified suggest that NBL spheroids better recapitulate in vivo tumor physiology.

The main fields of application of NBL spheroids are studies on drug discovery [290], radiosensitivity/ radioresistance [291], targeted radiotherapy [292], new therapeutic strategies [293] or mechanisms of tumor initiation and progression [294].

Neuroblastoma cell lines are also used as a model for neurodegenerative diseases, due their ability to differentiate into neuronal like cells. Indeed, it is well established that the 2D cultured human NBL cell line SH-SY5Y [295] can be differentiated into several neural cell phenotypes using agents such as retinoic acid (RA) [296] or brain-derived neurotrophic factor (BDNF) [297].

The use of neuroblastoma SH-SY5Y spheroid cultures further improved the model of neuronal differentiated tissues. Jung and coworkers [289] have evaluated the differentiating action of RA on SH-SY5Y spheroids. They showed that the expression of neuronal markers (synaptophysin, neuron-specific enolase- NSE), the contents of cell adhesion molecules and ECM proteins, and the ability to extend neurites were much higher in RA-treated spheroids than in RAtreated monolayer cells [289]. Interestingly, Seidel and collaborators [298] succeeded in differentiating $\mathrm{SH}$ SY5Y spheroids without the need of differentiation promoting agents, by cultivating them in a gyratory shaker. This neuronal 3D-culture model was then used to study the contribution of the protein TAU in the neurodegenerative processes.

\subsubsection{D Invasion Assays}

Invasiveness is an important feature of all metastatic tumors, so that invasion assays are widely used tools in neuroblastoma research. In 3D conditions, Matrigel ${ }^{\mathrm{TM}}$ invasion chamber assay is one of the most popular method [299-305], together with the invasion assays through 3D collagen gels [306]. Thanks to these studies, the effects of ionizing radiation [307], differentiating agents [299, 301], antitumoral drugs/molecules [303-305] or the contribution of specific oncogenes [300, 302] on invasiveness have been explored.

\subsubsection{NBL Cells on Scaffolds}

Neuroblastoma 3D culture embedded in soft matrices, like agarose, Matrigel ${ }^{\mathrm{TM}}$ or collagen, is widely used by scientists [299-305, 308]. Valero and coworkers [309], have studied the impact of different soft matrices on neuronal differentiation of the Neuro2a neuroblastoma cell line (N2a), evaluated with a novel impedimetric biosensor. The authors showed that neither agarose nor bare collagen was able to support the differentiation of $\mathrm{N} 2 \mathrm{a}$ cells. On the contrary, collagen-laminin mixture was able to do it by promoting the appearance of long neurites, touching the adjacent neurons.

Besides the common matrices, new biomolecules have been explored, such as the bacterial nanocellulose, excreted by Gluconacetobacter xylinus [310], or synthesized materials such as poly (L-lactic acid) PLL [311], photocurable polylactide (PLA) resin [312], poly(DL-lactide-co-glycolide) acid [313], carbon structures [314] or polymeric microspheres [315]. However, the main applicative field, by using these new materials, is not the NBL cancer research, but the neural tissue engineering, thanks to the properties of NBL cells to form neuron-like tissues.

\subsubsection{Bioreactors}

Literature is poor regarding papers presenting data obtained with bioreactors in the NBL cancer research 
field. However, the application potential of this experimental model is interesting, as suggested by Redder and coworkers [316, 317]. These authors have demonstrated that the study in the microgravity rotary bioreactors of the cellular in vitro aggregation kinetics and organoid morphology correlate to the neuroblastoma malignant potential. Amplified- MYCN or TrkB expressing neuroblastoma cell lines, with unfavorable outcomes, aggregated much more rapidly than unamplified MYCN or TrkA expressing neuroblastoma cell lines. Moreover, the authors observed differences in organoid morphology between the two groups. The authors then proposed the microgravity assay as a rapid and reproducible in vitro assessment of neuroblastoma malignant potential.

By using a rocking bioreactor system, an interesting application in NBL medical treatment was proposed by Rujkijyanont and coworkers [318]. CD56+ natural killer (NK) immune cells isolated from peripheral blood cells of normal donors and NBL patients were cultured and expanded in the rocking bioreactor. After the culturing, expanded CD56+ cells showed a marked increase of cytolytic activity on all the NBL cells studied. This procedure can represent a new therapeutical strategy in order to generate autologous or allogeneic CD56+ cells able to kill NBL cells but with a low risk of Graft versus Host Disease- GVHD.

\section{CLOSING REMARKS}

Since the 1980s, 3D culture has known a great evolution, that completely refined the scientific approach to cancer biology. The "third" dimension provided to in vitro cultured cells a new context, favoring normal and cancer cells/matrix interactions and cross-talk, thus mimicking, in a more natural way, the tumor microenvironment. This cancer hallmark plays a crucial function in regulating tumor behavior and survival, but it still needs to be better understood in order to be used in targeted cancer therapy. The 3D cell culture is a potent tool to model normal and pathological tissues, in order to increase our basic knowledge in tumor evolution (initiation, progression and invasion), as well as to better target oncological therapy.

However, even if great scientific and technical efforts have been made, there is not yet, at present, the perfect in vitro model able to exactly mimic tumor cells and its microenvironment, as it exists in the patient. As indicated by the literature, several 3D culture models are able optimally to represent many cancer hallmarks /outcomes. Nevertheless, none of these models can reproduce with accuracy the whole and complex in vivo tumor context, even if each one provides valid scientific information to assess tumor biology and anti-tumoral drugs efficacy/resistance. We still lack the ideal model that can be translated from lab benches to preclinical trials and to personalised cancer treatment. But the questions are: can such a model exist? Can/must a singular in vitro model mirror the complexity of a wide range of cancers? Can a so complex condition be translated into a simplified in vitro/ex vivo system? In effect, because our knowledge on cancer(s) is still partial, a number of queries are not answered.

Thus, for the next steps, it is imperative that oncology research includes multidisciplinary competences (engineers, physicists, biologists, healthcare doctors, oncologists, pharmacologists, toxicologists, etc.), in order to better concentrate efforts and define the basic, pre-clinical and clinical endpoints, as well as the experimental strategies to reach such objectives.

\section{REFERENCES}

[1] American Cancer Society. Cancer Facts \& Figures 2014 Atlanta: American Cancer Society; 2014. Available from: http: //www.cancer.org/research/cancerfactsstatistics/allcancerfact sfigures/index

[2] Ferlay J, Steliarova-Foucher E, Lortet-Tieulent J, Rosso S, Coebergh JW, Comber $\mathrm{H}$, et al. Cancer incidence and mortality patterns in Europe: estimates for 40 countries in 2012. Eur J Cancer 2013; 49(6): 1374-403. http://dx.doi.org/10.1016/j.ejca.2012.12.027

[3] Malvezzi M, Bertuccio P, Levi F, La Vecchia C, Negri E. European cancer mortality predictions for the year 2013. Ann Oncol 2013; 24(3): 792-800. http://dx.doi.org/10.1093/annonc/mdt010

[4] Wards E, DeSantis C, Robbins A, Kohler B, Jemal A. Childhood and Adolescent Cancer Statistics, CA Cancer J Clin 2014; 64(2): 83-103.

[5] Lu J, Getz G, Miska EA, Alvarez-Saavedra E, Lamb J, Peck $D$, et al. MicroRNA expression profiles classify human cancers. Nature 2005; 435: 834-8. http://dx.doi.org/10.1038/nature03702

[6] Hanahan D, Weinberg RA. Hallmarks of cancer: the next generation. Cell 2011; 144: 646-674. http://dx.doi.org/10.1016/j.cell.2011.02.013

[7] Brabletz T, Jung A, Reu S, Porzner M, Hlubek F, KunzSchughart LA, et al. Variable beta-catenin expression in colorectal cancers indicates tumor progression driven by the tumor environment. Proc Natl Acad Sci USA 2001; 98(18): 10356-61.

http://dx.doi.org/10.1073/pnas.171610498

[8] Eberle KE, Sansing HA, SzaniszloP, Resto VA, Berrier AL. Carcinoma matrix controls resistance to cisplatin through talin regulation of NF-kB. PLoS One 2011; 6(6): e21496. http://dx.doi.org/10.1371/journal.pone.0021496

[9] Egeblad M, Nakasone ES, Werb Z. Tumors as organs: complex tissues that interface with the entire organism, Dev Cell 2010; 18: 884-901. http://dx.doi.org/10.1016/j.devcel.2010.05.012 
[10] Gomes FG, Nedel F, Alves AM, Nör JE, Tarquinio SB. Tumor angiogenesis and lymphangiogenesis: tumor/endothelial crosstalk and cellular/microenvironmental signaling mechanisms. Life Sci 2013; 92(2): 101-7.

http://dx.doi.org/10.1016/j.lfs.2012.10.008

[11] Ghajar CM, Peinado H, Mori H, Matei IR, Evason KJ, Brazier $\mathrm{H}$, et al. The perivascular niche regulates breast tumor dormancy. Nat Cell Biol 2013; 15: 807-17. http://dx.doi.org/10.1038/ncb2767

[12] Kaatsch P. Epidemiology of childhood cancer. Cancer Treat Rev 2010; 36(4): 277-85. http://dx.doi.org/10.1016/j.ctrv.2010.02.003

[13] Scotting PJ, Waker DA, Perilongo G. Childhood solid tumors: a developmental disorder. Nature Rev Cancer 2005; 5(6): 481-8. http://dx.doi.org/10.1038/nrc1633

[14] Hu M, Yao J, Carroll DK, Weremowicz S, Chen H, Carrasco $\mathrm{D}$, et al. Regulation of in situ to invasive breast carcinoma transition. Cancer Cell 2008; 13: 394-406. http://dx.doi.org/10.1016/j.ccr.2008.03.007

[15] López-Otín C, Matrisian LM. Emerging roles of proteases in tumor suppression. Nat Rev Cancer 2007; 7(10): 800-8. http://dx.doi.org/10.1038/nrc2228

[16] Dusek RL, Attardi LD. Desmosomes: new perpetrators in tumor suppression. Nat Rev Cancer 2011; 11(5): 317-23. http://dx.doi.org/10.1038/nrc3051

[17] Hattar R, Maller O, McDaniel S, Hansen KC, Hedman KJ, Lyons TR, et al. Tamoxifen induces pleiotrophic changes in mammary stroma resulting in extracellular matrix that suppresses transformed phenotypes. Breast Cancer Res 2009; 11(1): R5.

http://dx.doi.org/10.1186/bcr2220

[18] Redon CE, Dickey JS, Nakamura AJ, Kareva IG, Naf D, Nowsheen $\mathrm{S}$, et al. Tumors induce complex DNA damage in distant proliferative tissues in vivo. Proc Natl Acad Sci USA 2010; 107(42): 17992-7.

http://dx.doi.org/10.1073/pnas.1008260107

[19] Tlsty TD, Hein PW. Know thy neighbor: stromal cells can contribute oncogenic signals. Curr Opin Genet Dev 2001; 11(1): $54-9$

http://dx.doi.org/10.1016/S0959-437X(00)00156-8

[20] Huang S, Ingber DE. A non-genetic basis for cancer progression and metastasis: self-organizing attractors in cell regulatory networks. Breast Disease 2006-2007; 2627-54.

[21] Kidd S, Spaeth E, Dembinski JL, Dietrich M, Watson K, Klopp A, et al. Direct evidence of mesenchymal stem cell tropism for tumor and wounding microenvironments using in vivo bioluminescent imaging. Stem Cells 2009; 27(10): 261423.

http://dx.doi.org/10.1002/stem.187

[22] Direkze NC, Hodivala-Dilke K, Jeffery R, Hunt T, Poulsom R, Oukrif D, et al. Bone marrow contribution to tumor-associated myofibroblasts and fibroblasts. Cancer Res 2004; 64(23): 8492-5.

http://dx.doi.org/10.1158/0008-5472.CAN-04-1708

[23] Spaeth EL, Dembinski JL, Sasser AK, Watson K, Klopp A, Hall $B$, et al. Mesenchymal stem cell transition to tumorassociated fibroblasts contributes to fibrovascular network expansion and tumor progression. PLoS ONE 4, 2009; 4(4): e4992.

[24] Bergfeld SA, DeClerk YA. Bone marrow derived mesenchymal stem cells and the tumor microenvironment. Cancer Metastasis Rev 2010; 29: 249-61. http://dx.doi.org/10.1007/s10555-010-9222-7

[25] Coussens LM, Werb Z. Inflammation and cancer. Nature 2002; 420: 860-7. http://dx.doi.org/10.1038/nature01322

[26] Mittal D, Gubin MM, Schreiber RD, Smyth MJ. New insights into cancer immunoediting and its three component phases- elimination, equilibrium and escape. Curr Opin Immunol 2014; 27C: 16-25.

[27] Coussens LM, Tinkle CL, Hanahan D, Werb Z. MMP-9 supplied by bone marrow-derived cells contributes to skin carcinogenesis. Cell 2000; 103(3): 481-90.

http://dx.doi.org/10.1016/S0092-8674(00)00139-2

[28] Green CE, Liu T, Montel V, Hsiao G, Lester RD, Subramaniam $\mathrm{S}$, et al. Chemoattractant signaling between tumor cells and macrophages regulates cancer cell migration, metastasis and neovascularization. PLoS One 2009; 21: 4(8): e6713.

[29] Lin CW, Shen SC, Ko CH, Lin HY, Chen YC. Reciprocal activation of macrophages and breast carcinoma cells by nitric oxide and colony-stimulating factor-1. Carcinogenesis 2010; 31(12): 2039-48. http://dx.doi.org/10.1093/carcin/bga172

[30] Sozzani S, Rusnati M, Riboldi E, Mitola S, Presta M. Dendritic cell-endothelial cell cross-talk in angiogenesis. Trends Immunol 2007; 28(9): 385-92. http://dx.doi.org/10.1016/j.it.2007.07.006

[31] Shurin MR, Shurin GV, Lokshin A, Yurkovetsky ZR, Gutkin DW, Chatta G, et al. Intratumoral cytokines/chemokines/ growth factors and tumor infiltrating dendritic cells: friends or enemies? Cancer Metastasis Rev 2006; 25(3): 333-56. http://dx.doi.org/10.1007/s10555-006-9010-6

[32] Fainaru O, Almog N, Yung CW, Nakai K, Montoya-Zavala M, Abdollahi $\mathrm{A}$, et al. Tumor growth and angiogenesis are dependent on the presence of immature dendritic cells. FASEB J 2010; 24(5): 1411-8. http://dx.doi.org/10.1096/fj.09-147025

[33] Lu J, Bai R, Qin Z, Zhang $Y$, Zhang $X$, Jiang $Y$, et al. Differentiation of immature DCs into endothelial-like cells in human esophageal carcinoma tissue homogenates. Oncol Rep 2013; 30(2): 739-44.

[34] Kessenbrock K, Plaks V, Werb Z. Matrix metalloproteinases: regulators of the tumor microenvironment. Cell 2010; 141(1): 52-67.

http://dx.doi.org/10.1016/j.cell.2010.03.015

[35] Conti P, Castellani ML, Kempuraj D, Salini V, Vecchiet J, Tetè $\mathrm{S}$, et al. Role of mast cells in tumor growth. Ann Clin Lab Sci 2007; 37(4): 315-22.

[36] Räsänen K, Vaheri A. Activation of fibroblasts in cancer stroma. Exp Cell Res 2010; 316(17): 2713-22. http://dx.doi.org/10.1016/j.yexcr.2010.04.032

[37] Kalluri R, Zeisberg M. Fibroblasts in cancer. Nat Rev Cancer 2006; 6: 392-401. http://dx.doi.org/10.1038/nrc1877

[38] Orimo A, Gupta PB, Sgroi DC, Arenzana-Seisdedos F, Delaunay $\mathrm{T}$, Naeem R, et al. Stromal fibroblasts present in invasive human breast carcinomas promote tumor growth and angiogenesis through elevated SDF-1/CXCL12 secretion. Cell $2005 ; 121(3): 335-48$. http://dx.doi.org/10.1016/j.cell.2005.02.034

[39] Hwang RF, Moore T, Arumugam T, Ramachandran V, Amos $\mathrm{KD}$, Rivera $\mathrm{A}$, et al. Cancer-associated stromal fibroblasts promote pancreatic tumor progression. Cancer Res 2008; 68(3): 918-26.

http://dx.doi.org/10.1158/0008-5472.CAN-07-5714

[40] Koukourakis MI, Giatromanolaki A, Harris AL, Sivridis E. Comparison of metabolic pathways between cancer cells and stromal cells in colorectal carcinomas: a metabolic survival role for tumor-associated stroma. Cancer Res 2006; 66(2): 632-7. http://dx.doi.org/10.1158/0008-5472.CAN-05-3260

[41] Marsh T, Pietras K, McAllister SS. Fibroblasts as architects of cancer pathogenesis. Biochim Biophys Acta 2013; 1832: 1070-8.

http://dx.doi.org/10.1016/j.bbadis.2012.10.013 
[42] Nieman KM, Romero IL, Van Houten B, Lengyel E. Adipose tissue and adipocytes support tumorigenesis and metastasis. Biochim Biophys Acta 2013; 1831(10): 1533-41. http://dx.doi.org/10.1016/j.bbalip.2013.02.010

[43] Manabe $Y$, Toda S, Miyazaki K, Sugihara H. Mature adipocytes, but not preadipocytes, promote the growth of breast carcinoma cells in collagen gel matrix culture through cancer-stromal cell interactions. J Pathol 2003; 201(2): 2218. http://dx.doi.org/10.1002/path.1430

[44] Onuma M, Bub JD, Rummel TL, Iwamoto $\mathrm{Y}$. Prostatecancercell-adipocyte interaction: leptin mediates androgen-independent prostate cancer cell proliferation through c-JunNH2-terminal kinase. J Biol Chem 2003; 278: 42660-7.

http://dx.doi.org/10.1074/jbc.M304984200

[45] Amemori S, Ootani A, Aoki S, Fujise T, Shimoda R, Kakimoto $\mathrm{T}$, et al. Adipocytes and preadipocytes promote the proliferation of colon cancer cells in vitro. Am J Physiol Gastrointest Liver Physiol 2007; 292(3): G923-9. http://dx.doi.org/10.1152/ajpgi.00145.2006

[46] Zhang Y, Daquinag AC, Amaya-Manzanares F, Sirin O, Tseng C, Kolonin MG. Stromal progenitor cells from endogenous adipose tissue contribute to pericytes and adipocytes that populate the tumor microenvironment. Cancer Res 2012; 72: 5198-208.

http://dx.doi.org/10.1158/0008-5472.CAN-12-0294

[47] Nagy JA, Chang SH, Dvorak AM, Dvorak HF. Why are tumor blood vessels abnormal and why is it important to know? $\mathrm{Br} \mathrm{J}$ Cancer 2009; 100(6): 865-9.

http://dx.doi.org/10.1038/sj.bjc.6604929

[48] Baeriswyl V, Christofori G. The angiogenic switch in carcinogenesis. Semin Cancer Biol 2009; 19(5): 329-37. http://dx.doi.org/10.1016/j.semcancer.2009.05.003

[49] Abramsson A, Lindblom P, Betsholtz C. Endothelial and nonendothelial sources of PDGF-B regulate pericyte recruitment and influence vascular pattern formation in tumors. J Clin Invest 2003; 112(8): 1142-51. http://dx.doi.org/10.1172/JCl200318549

[50] Visvader JE, Lindeman GJ. Cancer stem cells: current status and evolving complexities. Cell Stem Cell 2012; 10(6): 71728.

\section{http://dx.doi.org/10.1016/j.stem.2012.05.007}

[51] Tang DG. Understanding cancer stem cell heterogeneity and plasticity. Cell Research 2012; 22: 457-472. http://dx.doi.org/10.1038/cr.2012.13

[52] Visvader JE, Lindeman GJ. Cancer stem cells in solid tumors: accumulating evidence and unresolved questions. Nat Rev Cancer 2008; 8(10): 755-68.

http://dx.doi.org/10.1038/nrc2499

[53] Colmone A, Amorim M, Pontier AL, Wang S, Jablonski E, Sipkins DA. Leukemic cells create bone marrow niches that disrupt the behavior of normal hematopoietic progenitor cells. Science 2008; 322(5909): 1861-5.

http://dx.doi.org/10.1126/science. 1164390

[54] Li H, Fan X, Houghton J. Tumor microenvironment: the role of the tumor stroma in cancer. J Cell Biochem 2007; 101(4): 805-15.

http://dx.doi.org/10.1002/jcb.21159

[55] Hua H., Li M, Luo T, Yancun Yin Y, JiangY. Matrix metalloproteinases in tumorigenesis: an evolving paradigm. Cell Mol Life Sci 2011; 68: 3853-68. http://dx.doi.org/10.1007/s00018-011-0763-x

[56] Goetz JG, Minguet S, Navarro-Lerida I, Lazcano JJ, Samaniego R, Calvo E, et al. Biomechanical remodeling of the microenvironment by stromal caveolin-1 favors tumor invasion and metastasis. Cell 2011; 146: 148-63. http://dx.doi.org/10.1016/j.cell.2011.05.040
[57] Mouw JK, Yui Y, Damiano L, Bainer RO, Lakins JN, Acerbi I, et al. Tissue mechanics modulate microRNA-dependent PTEN expression to regulate malignant progression. Nat Med 2014; 20(4): 360-7.

http://dx.doi.org/10.1038/nm.3497

[58] Ulrich TA, de Juan Pardo EM, Kumar S. The mechanical rigidity of the extracellular matrix regulates the structure, motility and proliferation of glioma cells. Cancer Res 2009; 69 (10): 4167-74.

[59] http://dx.doi.org/10.1158/0008-5472.CAN-08-4859

[60] Paszek MJ, Zahir N, Johnson KR, Lakins JN, Rozenberg GI, Gefen $A$, et al. Tensional homeostasis and the malignant phenotype. Cancer Cell 2005; 8: 241-54. http://dx.doi.org/10.1016/j.ccr.2005.08.010

[61] Zutter MM, Santoro SA, Staatz WD, Tsung YL. Reexpression of the alpha 2 beta 1 integrin abrogates the malignant phenotype of breast carcinoma cells. Proc Natl Acad Sci USA 1995; 92(16): 7411-5.

http://dx.doi.org/10.1073/pnas.92.16.7411

[62] Desgrosellier JS, Cheresh DA. Integrins in cancer: biological implications and therapeutic opportunities. Nat Rev Cancer 2010 10(1): 9-22

http://dx.doi.org/10.1038/nrc2748

[63] Kalluri R. Basement membranes: structure, assembly and role in tumor angiogenesis. Nat Rev Cancer 2003; 3(6): 42233.

\section{http://dx.doi.org/10.1038/nrc1094}

[64] Lawler J., Detmar M. Tumor progression: the effects of thrombospondin-1 and -2. The International Int J Biochem Cell Biol 2004; 36(6): 1038-45. http://dx.doi.org/10.1016/j.biocel.2004.01.008

[65] Kalluri R. Discovery of type IV collagen non- collagenous domains as novel integrin ligands and endogenous inhibitors of angiogenesis. Cold Spring Harb Symp Quant Biol 2002; 67: 255-66.

http://dx.doi.org/10.1101/sqb.2002.67.255

[66] Barcellos-Hoff MH, Park C, Wright EG. Radiation and the microenvironment tumorigenesis and therapy. Nat Rev Cancer 2005; 5(11): 867-75. http://dx.doi.org/10.1038/nrc1735

[67] Tubiana M. Prevention of cancer and the dose-effect relationship: the carcinogenic effects of ionizing radiation. Cancer Radiother 2009; 13(4): 238-58.

http://dx.doi.org/10.1016/j.canrad.2009.03.003

[68] Lorusso G, Rüegg $\mathrm{C}$. The tumor microenvironment and its contribution to tumor evolution toward metastasis. Histochem Cell Biol 2008; 130(6): 1091-103. http://dx.doi.org/10.1007/s00418-008-0530-8

[69] Gomez-Roca C, Delord JP. Emerging new anticancer therapies in 2013. Curr Opin Oncol 2014; 26: 357-62. http://dx.doi.org/10.1097/CCO.0000000000000081

[70] Mazzoleni G, Di Lorenzo D, Steimberg N. Modelling tissues in 3D: the next future of pharmaco-toxicology and food research? Genes Nutr 2009; 4(1): 13-22. http://dx.doi.org/10.1007/s12263-008-0107-0

[71] Russell WMS, Burch RL.The Principles of Humane Experimental Technique. London UK: Methuen. 1959.

[72] Weaver VM, Petersen OW, Wang F, Larabell CA, Briand P, Damsky $\mathrm{C}$, et al. Reversion of the malignant phenotype of human breast cells in three-dimensional culture and in vivo by integrin blocking antibodies. J Cell Biol 1997; 137(1): 23145.

http://dx.doi.org/10.1083/jcb.137.1.231

[73] Weaver VM, Lelièvre S, Lakins JN, Chrenek MA, Jones JC, Giancotti $F$, et al. beta4 integrin-dependent formation of polarized three-dimensional architecture confers resistance to apoptosis in normal and malignant mammary epithelium. Cancer Cell 2002; 2(3): 205-16. http://dx.doi.org/10.1016/S1535-6108(02)00125-3 
[74] Debnath, J., Senthil K, Muthuswamy SK, Brugge JS. Morphogenesis and oncogenesis of MCF-10A mammary epithelial acini grown in three-dimensional basement membrane. Methods 2003; 30: 256-68.

http://dx.doi.org/10.1016/S1046-2023(03)00032-X

[75] Luca AC, Mersch S, Deenen R, Schmidt S, Messner I, Schäfer $\mathrm{KL}$ et al. Impact of the $3 \mathrm{D}$ microenvironment on phenotype, gene expression, and EGFR inhibition of colorectal cancer cell lines. PLoS One 2013; 8(3): e59689.

[76] Padrón JM, van der Wilt CL, Smid K, Smitskamp-Wilms E, Backus HH, Pizao PE, et al. The multilayered postconfluent cell culture as a model for drug screening. Crit Rev Oncol Hematol 2000; 36(2-3): 141-57. http://dx.doi.org/10.1016/S1040-8428(00)00083-4

[77] Mazzoleni G, Steimberg N New Models for the In vitro Study of Liver Toxicity: 3D Culture Systems and the Role of Bioreactors, The Continuum of Health Risk Assessments, Dr. Michael G. Tyshenko Ed. 2012.

[78] Fischbach C. Engineering tumors with 3D scaffolds. 2007 Nat Methods 4, 855-60. http://dx.doi.org/10.1038/nmeth1085

[79] Horning JL, Sahoo SK, Vijayaraghavalu S, Dimitrijevic S, Vasir JK, Jain TK, et al. 3-D tumor model for in vitro evaluation of anticancer drugs. Mol Pharm 2008; 5(5): 84962.

http://dx.doi.org/10.1021/mp800047v

[80] Windus LC, Kiss DL, Glover T, Avery VM. In vivo biomarker expression patterns are preserved in $3 \mathrm{D}$ cultures of Prostate Cancer. Exp Cell Res 2012; 15: 318(19): 2507-19.

[81] Bissell MJ. Architecture Is the Message: The role of extracellular matrix and 3-D structure in tissue-specific gene expression and breast cancer. Pezcoller Found J 2007; 16(29): 2-17.

[82] Wang X, Kaplan DL. Hormone-responsive 3D multicellular culture model of human breast tissue. Biomaterials 2012; 33: 3411-20.

http://dx.doi.org/10.1016/j.biomaterials.2012.01.011

[83] Feder-Mengus C, Ghosh S, Reschner A, Martin I, Spagnoli GC. New dimensions in tumor immunology: what does 3D culture reveal? Trends Mol Med 2008; 14(8): 333-40. http://dx.doi.org/10.1016/j.molmed.2008.06.001

[84] Zschenker O, Streichert T, Hehlgans S, Cordes N. Genomewide gene expression analysis in cancer cells reveals $3 \mathrm{D}$ growth to affect ECM and processes associated with cell adhesion but not DNA repair. PLoS One 2012; 7(4): e34279. http://dx.doi.org/10.1371/journal.pone.0034279

[85] Friedl P, Brocker EB. The biology of cell locomotion within three-dimensional extracellular matrix. Cell Mol Life Sci 2000; 57: 41-64. http://dx.doi.org/10.1007/s000180050498

[86] Nelson, C.M., and Bissell, M.J. Of extracellular matrix, scaffolds, and signaling: tissue architecture regulates development, homeostasis, and cancer. Annu Rev Cell Dev Biol 2006; 22: 287-309.

http://dx.doi.org/10.1146/annurev.cellbio.22.010305.104315

[87] Ferrarini M, Mazzoleni G, Steimberg N, Belloni D, Ferrero E. Innovative Models to Assess Multiple Myeloma Biology and the Impact of Drugs, Multiple Myeloma - A Quick Reflection on the Fast Progress, Prof. Roman Hajek (Ed.) 2013.

[88] Simon KA, Park KM, Mosadegh $B$, Subramaniam AB, Mazzeo AD, Ngo PM, et al. Polymer-based mesh as supports for multi-layered 3D cell culture and assays. Biomaterials 2014; 35(1): 259-68. http://dx.doi.org/10.1016/j.biomaterials.2013.09.049

[89] Steimberg N, Boniotti J, Mazzoleni G. 3D culture of primary chondrocytes, cartilage, and Bone/cartilage explants in simulated microgravity. In: Methods in Bioengineering: Alternative Technologies to Animal Testing, Maguire and Novak, pp. 205- 212, Boston, USA 2010.
[90] Mehta G, Hsiao AY, Ingram M, Luker GD, Takayama S. Opportunities and challenges for use of tumor spheroids as models to test drug delivery and efficacy. J Control Release 2012; 10; 164(2): 192-204.

[91] Shin CS, Kwak B., Han B, Park K. Development of an in vitro 3D tumor model to study therapeutic efficiency of an anticancer drug. Mol Pharm 2013; 10(6): 2167-75. http://dx.doi.org/10.1021/mp300595a

[92] Sutherlan R, Carlsson J, Durand R, Yuhas J. Spheroids in cancer research. Cancer Res 1981, 41: 2980-4.

[93] Kunz-Schughart LA, Kreutz M, Knuechel R. Multicellular spheroids: a three-dimensional in vitro culture system to study tumor biology. Int J Exp Pathol 1998; 79(1): 1-23. http://dx.doi.org/10.1046/j.1365-2613.1998.00051.x

[94] Takagi A, Watanabe M, Ishii Y, Morita J, Hirokawa $Y$, Matsuzaki $\mathrm{T}$, et al. Three-dimensional cellular spheroid formation provides human prostate tumor cells with tissuelike features. Anticancer Res 2007; 27(1A): 45-53.

[95] Pickl M, Ries $\mathrm{CH}$. Comparison of $3 \mathrm{D}$ and $2 \mathrm{D}$ tumor models reveals enhanced HER2 activation in 3D associated with an increase response to trastuzumab. Oncogene 2009; 28: 4618.

http://dx.doi.org/10.1038/onc.2008.394

[96] Chitcholtan K, Sykes PH, Evans JJ. The resistance of intracellular mediators to doxorubicin and cisplatin are distinct in 3D and 2D endometrial cancer. J Transl Med 2012; 10: 38.

http://dx.doi.org/10.1186/1479-5876-10-38

[97] Liu L, Yang M, Kang R, Wang Z, Zhao Y, Yu Y, et al. DAMPmediated autophagy contributes to drug resistance. Autophagy 2011; 7(1): 112-4.

http://dx.doi.org/10.4161/auto.7.1.14005

[98] McMillin DW, Negri JM, Mitsiades CS. The role of tumorstromal interactions in modifying drug response: challenges and opportunities, Nat Rev Drug Discov 2013; 12: 217-28. http://dx.doi.org/10.1038/nrd3870

[99] Wenzel C, Riefke B, Gründemann S, Krebs A, Christian S, Prinz $\mathrm{F}$, et al. 3D high-content screening for the identification of compounds that target cells in dormant tumor spheroid regions. Exp Cell Res 2014; 323(1): 131-43. http://dx.doi.org/10.1016/j.yexcr.2014.01.017

[100] Fischbach C, Kong HJ, Hsiong SX, Evangelista MB, Yuen W, Mooney DJ. Cancer cell angiogenic capability is regulated by 3D culture and integrin engagement. Proc Natl Acad Sci USA 2009; 106(2): 399-404. http://dx.doi.org/10.1073/pnas.0808932106

[101] Schrader J, Gordon-Walker TT, Aucott RL, van Deemter M, Quaas A, Walsh S, et al. Matrix stiffness modulates proliferation, chemotherapeutic response, and dormancy in hepatocellular carcinoma cells. Hepatology 2011; 53(4): 1192-205. http://dx.doi.org/10.1002/hep.24108

[102] Ekert JE, Johnson K, Strake B, Pardinas J, Jarantow S, Perkinson $\mathrm{R}$, et al. Three-dimensional lung tumor microenvironment modulates therapeutic compound responsiveness in vitro - implication for drug development. PLoS One 2014; 17; 9(3): e92248.

[103] Rama-Esendagli D, Esendagli G, Yilmaz G, Guc D. Spheroid formation and invasion capacity are differentially influenced by co-cultures of fibroblast and macrophage cells in breast cancer. Mol Biol Rep 2014 in press. http://dx.doi.org/10.1007/s11033-014-3144-3

[104] Seidl P, Huettinger $R$, Knuechel R,Kunz-Schughart LA. Three-dimensional fibroblast-tumor cell interaction causes downregulation of RACK1 mRNA expression in breast cancer cells in vitro. Int J Cancer 2002; 102: 129-36. http://dx.doi.org/10.1002/ijc.10675

[105] Ghosh S, Joshi MB, Ivanov D, Feder-Mengus C, Spagnoli $\mathrm{GC}$, Martin I, et al. Use of multicellular tumor spheroids to 
dissect endothelial cell-tumor cell interactions: a role for Tcadherin in tumor angiogenesis. FEBS Lett 2007; 581: 45238.

http://dx.doi.org/10.1016/j.febslet.2007.08.038

[106] Beaumont KA, Mohana-Kumaran N, Haass NK. Modeling Melanoma In vitro and In vivo. Healthcare. 2014; 2(1): 27-46. http://dx.doi.org/10.3390/healthcare2010027

[107] Pizzimenti S, Ciamporcero E, Pettazzoni P, Osella-Abate S, Novelli $\mathrm{M}$, Toaldo $\mathrm{C}$, et al. The inclusion complex of 4hydroxynonenal with a polymeric derivative of $\beta$-cyclodextrin enhances the antitumoral efficacy of the aldehyde in several tumor cell lines and in a three-dimensional human melanoma model. Free Radic Biol Med 2013; 65: 765-77. http://dx.doi.org/10.1016/j.freeradbiomed.2013.06.035

[108] Marrero B, Messina JL, Heller R. Generation of tumor spheroid in a microgravity environment as a $3 \mathrm{D}$ model of melanoma. In vitro Cell Dev Biol Anim 2009; 45(9): 523-34. http://dx.doi.org/10.1007/s11626-009-9217-2

[109] Frantz C, Stewart KM, Weaver VM. The extracellular matrix at a glance. J Cell Sci 2010; 123(Pt 24): 4195-200. http://dx.doi.org/10.1242/jcs.023820

[110] Chang SS, Guo W-h, Kim Y, and Wang Y-I. Guidance of Cell Migration by Substrate Dimension. Biophys J 2013; 104(2): 313-21.

http://dx.doi.org/10.1016/j.bpj.2012.12.001

[111] Kleinman HK, McGarvey ML, Liotta LA, Robey PG, Tryggvason K, Martin GR. Isolation and characterization of type IV procollagen, laminin, and heparan sulfate proteoglycan from the EHS sarcoma. Biochemistry 1982; 21: 6188-93.

http://dx.doi.org/10.1021/bi00267a025

[112] Vukicevic S, Kleinman HK, Luyten FP, Roberts AB, Roche NS, Reddi AH. Identification of multiple active growth factors in basement membrane Matrigel suggests caution in interpretation of cellular activity related to extracellular matrix components. Exp Cell Res 1992; 202: 1-8. http://dx.doi.org/10.1016/0014-4827(92)90397-Q

[113] Cichon MA, Gainullin VG, Zhang Y, Radisky DC. Growth of lung cancer cells in three-dimensional microenvironments reveals key features of tumor malignancy. Integr Biol (Camb). 2012; 4(4): 440-8. http://dx.doi.org/10.1039/c1ib00090

[114] Zhang X, Fournier MV, Ware JL, Bissell MJ, Yacoub A, Zehner ZE. Inhibition of vimentin or beta1 integrin reverts morphology of prostate tumor cells grown in laminin-rich extracellular matrix gels and reduces tumor growth in vivo. Mol Cancer Ther 2009; 8(3): 499-508.

http://dx.doi.org/10.1158/1535-7163.MCT-08-0544

[115] Windus LC, Glover TT, Avery VM. Bone-stromal cells upregulate tumorigenic markers in a tumor-stromal 3D model of prostate cancer. Molecular Cancer 2013; 12: 112. http://dx.doi.org/10.1186/1476-4598-12-112

[116] Xu X, Gurski LA, Zhang C, Harrington DA, Farach-Carson $\mathrm{MC}$, Jia X. Recreating the tumor microenvironment in a bilayer, hyaluronic acid hydrogel construct for the growth of prostate cancer spheroids. Biomaterials. 2012; 33(35): 904960.

http://dx.doi.org/10.1016/j.biomaterials.2012.08.061

[117] Gurski LA, Jha AK, Zhang C, Jia X, Farach-Carson MC Hyaluronic acid-based hydrogels as 3D matrices for in vitro evaluation of chemotherapeutic drugs using poorly adherent prostate cancer cells. Biomaterials 2009; 30(30): 6076-85. http://dx.doi.org/10.1016/j.biomaterials.2009.07.054

[118] Dhiman HK, Ray AR, Panda AK. Three-dimensional chitosan scaffold-based MCF-7 cell culture for the determination of the cytotoxicity of tamoxifen. Biomaterials 2005; 26(9): 979-86. http://dx.doi.org/10.1016/j.biomaterials.2004.04.012

[119] Kaemmerer E, Melchels FP, Holzapfel BM, Meckel T, Hutmacher DW, Loessner D. Gelatine methacrylamide-based hydrogels: An alternative three-dimensional cancer cell culture system. Acta Biomater. 2014; S1742-7061(14)000877.

[120] Liu J, Tan Y, Zhang H, Zhang Y, Xu P, Chen J, et al. Soft fibrin gels promote selection and growth of tumorigenic cells. Nat Mater 2012; 11: 734-41. http://dx.doi.org/10.1038/nmat3361

[121] Szot CS, Buchanan CF, Freeman JW, Rylander MN. 3D in vitro bioengineered tumors based on collagen I hydrogels. Biomaterials 2011; 32: 7905-12. http://dx.doi.org/10.1016/..biomaterials.2011.07.001

[122] Fong EL, Lamhamedi-Cherradi SE, Burdett E, Ramamoorthy V, Lazar AJ, Kasper FK, et al. Modeling Ewing sarcoma tumors in vitro with 3D scaffolds. Proc Natl Acad Sci USA 2013; 110(16): 6500-5 http://dx.doi.org/10.1073/pnas.1221403110

[123] Linde N, Gutschalk CM, Hoffmann C, Yilmaz D, Mueller MM Integrating macrophages into organotypic co-cultures: a 3D in vitro model to study tumor-associated macrophages. PLoS One 2012; 7(7): e40058

[124] Cukierman E, Pankov R, Yamada KM. Cell interactions with three-dimensional matrices. Curr Opin Cell Biol 2002; 14: 633-9.

http://dx.doi.org/10.1016/S0955-0674(02)00364-2

[125] Wang X, Sun L, Maffini MV, Soto A, Sonnenschein C, Kaplan DL. A complex 3D human tissue culture system based on mammary stromal cells and silk scaffolds for modeling breast morphogenesis and function. Biomaterials. 2010; 31(14): 3920-9. http://dx.doi.org/10.1016/j.biomaterials.2010.01.118

[126] Kievit FM, Florczyk SJ, Leung MC, Veiseh O, Park JO, Disis $\mathrm{ML}$, et al. Chitosan-alginate $3 \mathrm{D}$ scaffolds as a mimic of the glioma tumor microenvironment. Biomaterials 2010; 31(22): 5903-10 http://dx.doi.org/10.1016/j.biomaterials.2010.03.062

[127] Dunne LW, Huang Z, Meng W, Fan X, Zhang N, Zhang Q, et al. Human decellularized adipose tissue scaffold as a model for breast cancer cell growth and drug treatments. Biomaterials 2014; 35(18): 4940-9. http://dx.doi.org/10.1016/j.biomaterials.2014.03.003

[128] Genovese L, Zawada L, Tosoni A, Ferri A, Zerbi P, Allevi R, et al. Cellular localization, invasion, and turnover are differently influenced by healthy and tumor-derived extracellular matrix. Tissue Eng Part A 2014, in press.

[129] El-Sherbiny IM, Yacoub MH Hydrogel scaffolds for tissue engineering: Progress and challenges. Glob Cardiol Sci Pract 2013; 3(3): 316-42.

[130] Battiston KG, Cheung JW, Jain D, Santerre JP. Biomaterials in co-culture systems: towards optimizing tissue integration and cell signaling within scaffolds. Biomaterials 2014; 35(15): 4465-76. http://dx.doi.org/10.1016/i.biomaterials.2014.02.023

[131] Kenny PA, Lee GY, Myers CA, Neve RM, Semeiks JR Spellman PT, et al. The morphologies of breast cancer cell lines in three-dimensional assays correlate with their profiles of gene expression. Mol Oncol 2007; 1(1): 84-96. http://dx.doi.org/10.1016/j.molonc.2007.02.004

[132] Grosso SH, Katayama ML, Roela RA, Nonogaki S, Soares $\mathrm{FA}$, Brentani $\mathrm{H}$, et al. Breast cancer tissue slices as a model for evaluation of response to rapamycin. Cell Tissue Res 2013; 352(3): 671-84. http://dx.doi.org/10.1007/s00441-013-1608-8

[133] Holliday DL, Moss MA, Pollock S, Lane S, Shaaban AM, Millican-Slater $\mathrm{R}$, et al. The practicalities of using tissue slices as preclinical organotypic breast cancer models. J Clin Pathol 2013; 66(3): 253-5. http://dx.doi.org/10.1136/jclinpath-2012-201147

[134] Jung S, Kim HW, Lee JH, Kang SS, Rhu HH, Jeong YI, et al. Brain tumor invasion model system using organotypic brain- 
slice culture as an alternative to in vivo model. J Cancer Res Clin Oncol 2002; 128(9): 469-76.

http://dx.doi.org/10.1007/s00432-002-0366-x

[135] Ferrarini M, Steimberg N, Ponzoni M, Belloni D, Berenzi A, Girlanda S, et al. Ex vivo dynamic 3-D culture of human tissues in the RCCS ${ }^{\mathrm{TM}}$ bioreactor allows the study of Multiple Myeloma biology and response to therapy. PLoS One 2013b; 8(8): e71613. http://dx.doi.org/10.1371/journal.pone.0071613

[136] Linabery AM, Ross JA. Trends in childhood cancer incidence in the U.S.(1992-2004). Cancer 2008; 112(2): 416-32. http://dx.doi.org/10.1002/cncr.23169

[137] Pui CH, Carroll WL, Meshinchi S, Arceci RJ. Biology, risk stratification, and therapy of pediatric acute leukemias: an update. J Clin Oncol 2011; 29(5): 551-65. http://dx.doi.org/10.1200/JCO.2010.30.7405

[138] Nilsson SK, Johnston HM, Coverdale JA. Spatial localization of transplanted hemopoietic stem cells: inferences for the localization of stem cell niches. Blood 2001; 97: 2293-9. http://dx.doi.org/10.1182/blood.V97.8.2293

[139] Calvi LM, Adams GB, Weibrecht KW, Weber JM, Olson DP, Knight MC, et al. Osteoblastic cells regulate the haematopoietic stem cell niche. Nature 2003; 425: 841-6. http://dx.doi.org/10.1038/nature02040

[140] Bryan AA, Link DC. Regulation of hematopoietic stem cells by bone marrow stromal cells. Trends Immunol 2014; 35(1): 32-7. http://dx.doi.org/10.1016/j.it.2013.10.002

[141] Al-Khaldi A, Eliopoulos N, Martineau D, Lejeune L, Lachapelle K, Galipeau J. Postnatal bone marrow stromal cells elicit a potent VEGF-dependent neoangiogenic response in vivo. Gene Ther 2003; 10: 621-9. http://dx.doi.org/10.1038/sj.gt.3301934

[142] Pittenger MF, Mackay AM, Beck SC, Jaiswal RK, Douglas R, Mosca JD, et al. Multilineage potential of adult human mesenchymal stem cells. Science 1999; 284: 143-7. http://dx.doi.org/10.1126/science.284.5411.143

[143] Klein G. The extracellular matrix of the hematopoietic microenvironment. Experientia 1995; 51: 914-926. http://dx.doi.org/10.1007/BF01921741

[144] Verfaillie C, Hurley R, Bhatia R, McCarthy JB. Role of bone marrow matrix in normal and abnormal hematopoiesis. Crit Rev Oncol Hematol 1994; 16: 201-24 http://dx.doi.org/10.1016/1040-8428(94)90071-X

[145] Nair RR, Tolentino J, Hazlehurst LA. The bone marrow microenvironment as a sanctuary for minimal residual disease in CML. Biochem Pharmacol 2010; 80(5): 602-12. http://dx.doi.org/10.1016/j.bcp.2010.04.003

[146] Ayala F, Dewar R, Kieran M, Kalluri R. Contribution of bone microenvironment to leukemogenesis and leukemia progression. Leukemia 2009; 23(12): 2233-41. http://dx.doi.org/10.1038/leu.2009.175

[147] Meads MB, Hazlehurst LA, Dalton WS. The bone marrow microenvironment as a tumor sanctuary and contributor to drug resistance. Clin Cancer Res 2008; 14(9): 2519-26. http://dx.doi.org/10.1158/1078-0432.CCR-07-2223

[148] Konopleva M, Konoplev S, Hu W, Zaritskey AY, Afanasiev BV, Andreeff M. Stromal cells prevent apoptosis of AML cells by up-regulation of anti-apoptotic proteins. Leukemia 2002; 16(9): 1713-24.

http://dx.doi.org/10.1038/sj.leu.2402608

[149] Jin L, Hope KJ, Zhai Q, Smadja-Joffe F, Dick JE. Targeting of CD44 eradicates human acute myeloid leukemic stem cells. Nat Med 2006; 12(10): 1167-74. http://dx.doi.org/10.1038/nm1483

[150] Benito J, Shi Y, Szymanska B, Carol H, Boehm I, Lu H, et al. Pronounced hypoxia in models of murine and human leukemia: high efficacy of hypoxia-activated prodrug PR-104. PLoS One 2011; 6(8): e23108.

http://dx.doi.org/10.1371/journal.pone.0023108

[151] Sison EA, Brown P. The bone marrow microenvironment and leukemia: biology and therapeutic targeting. Expert Rev Hematol 2011; 4(3): 271-83.

http://dx.doi.org/10.1586/ehm.11.30

[152] Konopleva M, Tabe Y, Zeng Z, Andreeff M. Therapeutic targeting of microenvironmental interactions in leukemia: mechanisms and approaches. Drug Resist Updat 2009; 12(45): 103-13. http://dx.doi.org/10.1016/j.drup.2009.06.001

[153] Blanco TM, Mantalaris A, Bismarck A, Panoskaltsis N. The development of a three-dimensional scaffold for ex vivo biomimicry of human acute myeloid leukaemia. Biomaterials 2010; 31(8): 2243-51. http://dx.doi.org/10.1016/j.biomaterials.2009.11.094

[154] Vu TT, Lim C, Lim M. Characterization of leukemic cell behaviors in a soft marrow mimetic alginate hydrogel. $\mathrm{J}$ Biomed Mater Res B Appl Biomater 2012; 100(7): 1980-8. http://dx.doi.org/10.1002/jbm.b.32765

[155] Dainiak MB, Savina IN, Musolino I, Kumar A, Mattiasson B, Galaev IY. Biomimetic macroporous hydrogel scaffolds in a high-throughput screening format for cell-based assays. Biotechnol Prog 2008; 24(6): 1373-83. http://dx.doi.org/10.1002/btpr.30

[156] Aljitawi OS, Li D, Xiao Y, Zhang D, Ramachandran K, Stehno-Bittel L, et al. A novel three-dimensional stromalbased model for in vitro chemotherapy sensitivity testing of leukemia cells. Leuk Lymphoma 2014; 55(2): 378-91. http://dx.doi.org/10.3109/10428194.2013.793323

[157] Usuludin SB, Cao X, Lim M. Co-culture of stromal and erythroleukemia cells in a perfused hollow fiber bioreactor system as an in vitro bone marrow model for myeloid leukemia. Biotechnol Bioeng 2012; 109(5): 1248-58. http://dx.doi.org/10.1002/bit.24400

[158] Kirshner J, Thulien KJ, Martin LD, Debes Marun C, Reiman $\mathrm{T}$, Belch AR, et al. A unique three-dimensional model for evaluating the impact of therapy on multiple myeloma. Blood 2008; 112(7): 2935-45.

http://dx.doi.org/10.1182/blood-2008-02-142430

[159] Hou L, Liu T, Tan J, Meng W, Deng L, Yu H et al. Long-term culture of leukemic bone marrow primary cells in biomimetic osteoblast niche. Int J Hematol 2009; 90(3): 2 81-91.

[160] Zhang W, Lee WY, Siegel DS, Tolias P, Zilberberg J. PatientSpecific 3D Microfluidic Tissue Model for Multiple Myeloma. Tissue Eng Part C Methods 2014. http://dx.doi.org/10.1089/ten.tec.2013.0490

[161] Khin ZP, Ribeiro ML, Jacobson T, Hazlehurst L, Perez L, Baz $\mathrm{R}$, et al. A preclinical assay for chemosensitivity in multiple myeloma. Cancer Res 2014; 74(1): 56-67. http://dx.doi.org/10.1158/0008-5472.CAN-13-2397

[162] Paguirigan AL, Beebe DJ. Microfluidics meet cell biology: bridging the gap by validation and application of microscale techniques for cell biological assays. Bioessays 2008; 30(9): 811-21. http://dx.doi.org/10.1002/bies.20804

[163] Kleinman HK, Jacob K. Invasion assays. Curr Protoc Cell Biol, Chapter 12. Unit 12.2. 2001.

[164] Pouliot N, Pearson HB, Burrows A. Investigating Metastasis Using In vitro Platforms. In: Madame Curie Bioscience Database [Internet]. Austin (TX): Landes Bioscience 2000.

[165] Daubon T, Chasseriau J, El Ali A, Rivet J, Kitzis A, Constantin B, et al. Differential motility of p190bcr-abl- and p210bcr-abl-expressing cells: respective roles of Vav and Bcr-Abl GEFs. Oncogene 2008; 27(19): 2673-85. http://dx.doi.org/10.1038/sj.onc. 1210933 
[166] Klemke M, Kramer E, Konstandin MH, Wabnitz GH, Samstag Y. An MEK-cofilin signalling module controls migration of human T cells in 3D but not 2D environments. EMBO J 2010; 29(17): 2915-29.

http://dx.doi.org/10.1038/emboj.2010.153

[167] Rochelle T, Daubon T, Van Troys M, Harnois T, Waterschoot $\mathrm{D}$, Ampe $\mathrm{C}$ et al. p210bcr-abl induces amoeboid motility by recruiting ADF/destrin through RhoA/ROCK1. FASEB J 2013; 27(1): 123-34.

http://dx.doi.org/10.1096/fj.12-205112

[168] Ivanoff J, Talme T, Sundqvist KG. The role of chemokines and extracellular matrix components in the migration of $T$ lymphocytes into three-dimensional substrata. Immunology 2005; 114(1): 53-62.

http://dx.doi.org/10.1111/j.1365-2567.2004.02005.x

[169] Talme T, Ivanoff $J$, Sundqvist KG. Somatostatin is a specific inhibitor of SDF-1alpha-induced $T$ cell infiltration. Clin Exp Immunol 2004; 135(3): 434-9.

http://dx.doi.org/10.1111/j.1365-2249.2003.02370.x

[170] da Silva J, Lautenschläger F, Sivaniah E, Guck JR. The cavity-to-cavity migration of leukaemic cells through 3D honey-combed hydrogels with adjustable internal dimension and stiffness. Biomaterials 2010; 31(8): 2201-8.

http://dx.doi.org/10.1016/j.biomaterials.2009.11.105

[171] Bruel A, Paschke S, Jainta S, Zhang Y, Vassy J, Rigaut JP, et al. Remodeling of vimentin cytoskeleton correlates with enhanced motility of promyelocytic leukemia cells during differentiation induced by retinoic acid. Anticancer Res 2001; 21: 3973-80.

[172] Cabral JMS. Ex vivo expansion of hematopoietic stem cells in bioreactors. Biotechnol Lett 2001; 23: 741-51. http://dx.doi.org/10.1023/A:1010350215989

[173] Tan J, Liu T, Hou L, Meng W, Wang Y, Zhi W, et al. Maintenance and expansion of hematopoietic stem/progenitor cells in biomimetic osteoblast niche. Cytotechnology 2010; 62(5): 439-48. http://dx.doi.org/10.1007/s10616-010-9297-6

[174] Xue C, Kwek KY, Chan JK, Chen Q, Lim M. The hollow fiber bioreactor as a stroma-supported, serum-free ex vivo expansion platform for human umbilical cord blood cells. Biotechnol J 2014. http://dx.doi.org/10.1002/biot.201300320

[175] Rao M, Ahrlund-Richter L, Kaufman DS. Concise review: cord blood banking, transplantation and induced pluripotent stem cell: success and opportunities. Stem Cells 2012; 30: $55 \mathrm{e} 60$.

[176] Caicedo-Carvajal CE, Liu Q, Remache Y, Goy A, Suh KS. Cancer tissue engineering: a novel $3 d$ polystyrene scaffold for in vitro isolation and amplification of lymphoma cancer cells from heterogeneous cell mixtures. J Tissue Eng 2011. http://dx.doi.org/10.4061/2011/362326

[177] Aldinucci D, Gloghini A, Pinto A, De Filippi R, Carbone A. The classical Hodgkin's lymphoma microenvironment and its role in promoting tumor growth and immune escape. J Pathol 2010; 221(3): 248-63. http://dx.doi.org/10.1002/path.2711

[178] Coupland SE. The challenge of the microenvironment in Bcell lymphomas. Histopathology 2011; 58(1): 69-80. http://dx.doi.org/10.1111/j.1365-2559.2010.03706.x

[179] Burger JA, Ghia P, Rosenwald A, Caligaris-Cappio F. The microenvironment in mature B-cell malignancies: a target for new treatment strategies. Blood 2009; 114(16): 3367-75. http://dx.doi.org/10.1182/blood-2009-06-225326

[180] Gravelle P, Jean C, Valleron W, Laurent G, Fournié JJ. Innate predisposition to immune escape in follicular lymphoma cells. Oncoimmunology 2012; 1(4): 555-556. http://dx.doi.org/10.4161/onci.19365

[181] Timmins NE, Dietmair S, Nielsen LK. Hanging-drop multicellular spheroids as a model of tumor angiogenesis.
Angiogenesis 2004; 7(2): 97-103. http://dx.doi.org/10.1007/s10456-004-8911-7

[182] Decaup E, Jean C, Laurent C, Gravelle P, Fruchon S, Capilla $\mathrm{F}$, et al. Anti-tumor activity of obinutuzumab and rituximab in a follicular lymphoma 3D model. Blood Cancer J 2013; 3: e131.

http://dx.doi.org/10.1038/bcj.2013.32

[183] Birgersdotter A, Baumforth KR, Porwit A, Sundblad A, Falk $\mathrm{KI}$, Wei W, et al. Three-dimensional culturing of the Hodgkin lymphoma cell-line L1236 induces a HL tissue-like gene expression pattern. Leuk Lymphoma 2007; 48(10): 2042-53. http://dx.doi.org/10.1080/10428190701573190

[184] Gelain F, Bottai D, Vescovi A, Zhang S. Designer selfassembling Peptide nanofiber scaffolds for adult mouse neural stem cell 3-dimensional cultures. PLoS ONE 2006; 1: e119.

http://dx.doi.org/10.1371/journal.pone.0000119

[185] Zhang S. Fabrication of novel biomaterials through molecular self-assembly. Nat Biotechnol 2003; 21(10): 1171-8. http://dx.doi.org/10.1038/nbt874

[186] Fleming AJ, Chi SN. Brain tumors in children. Curr Probl Pediatr Adolesc Health Care 2012; 42(4): 80-103. http://dx.doi.org/10.1016/j.cppeds.2011.12.002

[187] Lathia JD, Gallagher J, Myers JT, Li M, Vasanji A, McLendon $\mathrm{RE}$, et al. Direct in vivo evidence for tumor propagation by glioblastoma cancer stem cells. PLoS One 2011; 6(9): e24807.

http://dx.doi.org/10.1371/journal.pone.0024807

[188] Heddleston JM, Hitomi M, Venere M, Flavahan WA, Yang K, Kim Y, et al. Glioma stem cell maintenance: the role of the microenvironment. Curr Pharm Des 2011; 17(23): 2386-401. http://dx.doi.org/10.2174/138161211797249260

[189] Griesinger AM, Birks DK, Donson AM, Amani V, Hoffman LM, Waziri A, et al. Characterization of distinct immunophenotypes across pediatric brain tumor types. J Immunol 2013; 191(9): 4880-8.

http://dx.doi.org/10.4049/jimmunol.1301966

[190] Charles NA, Holland EC, Gilbertson R, Glass R, Kettenmann $\mathrm{H}$. The brain tumor microenvironment. Glia 2011; 59(8): 1169-80. http://dx.doi.org/10.1002/glia.21136

[191] Lewis CE, Pollard JW. Distinct role of macrophages in different tumor microenvironments. Cancer Res 2006; 66: 605-612.

http://dx.doi.org/10.1158/0008-5472.CAN-05-4005

[192] Nishie A1, Ono M, Shono T, Fukushi J, Otsubo M, Onoue $H$, et al. Macrophage infiltration and heme oxygenase-1 expression correlate with angiogenesis in human gliomas. Clin Cancer Res 1999; 5: 1107-1113.

[193] Diederichsen, AC, Hjelmborg Jv, Christensen PB, Zeuthen J, Fenger $C$. Prognostic value of the CD4+/CD8+ ratio of tumor infiltrating lymphocytes in colorectal cancer and HLA-DR expression on tumor cells. Cancer Immunol Immunother 2003; 52: 423-28. http://dx.doi.org/10.1007/s00262-003-0388-5

[194] El Andaloussi A, Lesniak MS. CD4+ CD25+ FoxP3+ T-cell infiltration and heme oxygenase-1 expression correlate with tumor grade in human gliomas. J Neurooncol 2007; 83(2): $145-52$.

http://dx.doi.org/10.1007/s11060-006-9314-y

[195] Banissi C, Ghiringhelli F, Chen L, Carpentier AF. Treg depletion with a low-dose metronomic temozolomide regimen in a rat glioma model. Cancer Immunol Immunother 2009; 58(10): 1627-34.

http://dx.doi.org/10.1007/s00262-009-0671-1

[196] Wade A, Robinson AE, Engler JR, Petritsch C, James CD, Phillips JJ. Proteoglycans and their roles in brain cancer. FEBS J 2013; 280(10): 2399-417. http://dx.doi.org/10.1111/febs.12109 
[197] Pedersen PH, Ness GO, Engebraaten O, Bjerkvig R, Lillehaug JR, Laerum OD. Heterogeneous response to the growth factors [EGF, PDGF (bb), TGF-alpha, bFGF, IL-2] on glioma spheroid growth, migration and invasion. Int $\mathrm{J}$ Cancer 1994; 56(2): 255-61. http://dx.doi.org/10.1002/ijc.2910560219

[198] De Witt Hamer PC, Van Tilborg AA, Eijk PP, Sminia P, Troost D, Van Noorden CJ et al. The genomic profile of human malignant glioma is altered early in primary cell culture and preserved in spheroids. Oncogene 2008; 27(14): 2091-6.

http://dx.doi.org/10.1038/sj.onc. 1210850

[199] Vinci M, Gowan S, Boxall F, Patterson L, Zimmermann M, Court W, et al. Advances in establishment and analysis of three-dimensional tumor spheroid-based functional assays for target validation and drug evaluation. BMC Biol 2012; 10: 29.

\section{http://dx.doi.org/10.1186/1741-7007-10-29}

[200] Temple S. Division and differentiation of isolated CNS blast cells in microculture. Nature 1989; 340(6233): 471-3. http://dx.doi.org/10.1038/340471a0

[201] Reynolds BA, Weiss S. Generation of neurons and astrocytes from isolated cells of the adult mammalian central nervous system. Science 1992; 255(5052): 1707-10. http://dx.doi.org/10.1126/science.1553558

[202] Deleyrolle LP, Rietze RL, Reynolds BA. The neurosphere assay, a method under scrutiny. Acta Neuropsychiatrica 2008; 20: 2-8.

http://dx.doi.org/10.1111/j.1601-5215.2007.00251.x

[203] Galli R, Binda E, Orfanelli U, Cipelletti B, Gritti A, De Vitis S. Isolation and characterization of tumorigenic, stem-like neural precursors from human glioblastoma. Cancer Res 2004; 64(19): 7011-21. http://dx.doi.org/10.1158/0008-5472.CAN-04-1364

[204] Hemmati HD, Nakano I, Lazareff JA, Masterman-Smith M, Geschwind DH, Bronner-Fraser M. Cancerous stem cells can arise from pediatric brain tumors. Proc Natl Acad Sci USA 2003; 100(25): 15178-83.

http://dx.doi.org/10.1073/pnas.2036535100

[205] Hasselbach LA, Irtenkauf SM, Lemke NW, Nelson KK, Berezovsky AD, Carlton ET et al. Optimization of high grade glioma cell culture from surgical specimens for use in clinically relevant animal models and 3D immunochemistry. J Vis Exp 2014; 83: e51088.

[206] Servidei T, Meco D, Trivieri N, Patriarca V, Vellone VG, Zannoni GF et al. Effects of epidermal growth factor receptor blockade on ependymoma stem cells in vitro and in orthotopic mouse models. Int J Cancer 2012; 131(5): E791803. http://dx.doi.org/10.1002/ijc.27377

[207] Yuan X, Curtin J, Xiong Y, Liu G, Waschsmann-Hogiu S, Farkas DL, et al. Isolation of cancer stem cells from adult glioblastoma multiforme. Oncogene 2004; 23(58): 9392-400. http://dx.doi.org/10.1038/sj.onc. 1208311

[208] Rietze RL, Reynolds BA. Neural stem cell isolation and characterization. Methods Enzymol 2006; 419: 3-23. http://dx.doi.org/10.1016/S0076-6879(06)19001-1

[209] Pavon LF, Marti LC, Sibov TT, Malheiros SM, Brandt RA, Cavalheiro S, Gamarra LF. In vitro Analysis of Neurospheres Derived from Glioblastoma Primary Culture: A Novel Methodology Paradigm. Front Neurol 2014; 4: 214. http://dx.doi.org/10.3389/fneur.2013.00214

[210] Galli R. The neurosphere assay applied to neural stem cells and cancer stem cells. Methods Mol Biol 2013; 986: 267-77. http://dx.doi.org/10.1007/978-1-62703-311-4 17

[211] Hardee ME, Marciscano AE, Medina-Ramirez CM, Zagzag D, Narayana A, Lonning SM, et al. Resistance of glioblastoma-initiating cells to radiation mediated by the tumor microenvironment can be abolished by inhibiting transforming growth factor- $\beta$. Cancer Res 2012; 72(16): 4119-29.

http://dx.doi.org/10.1158/0008-5472.CAN-12-0546

[212] Ying M, Wang S, Sang Y, Sun P, Lal B, Goodwin CR, et al. Regulation of glioblastoma stem cells by retinoic acid: role for Notch pathway inhibition. Oncogene 2011; 30(31): 3454-67. http://dx.doi.org/10.1038/onc.2011.58

[213] Bar EE, Lin A, Mahairaki V, Matsui W, Eberhart CG. Hypoxia increases the expression of stem-cell markers and promotes clonogenicity in glioblastoma neurospheres. Am J Pathol 2010; 177(3): 1491-502.

http://dx.doi.org/10.2353/ajpath.2010.091021

[214] Salmaggi A, Boiardi A, Gelati M, Russo A, Calatozzolo C, Ciusani $\mathrm{E}$ et al. Glioblastoma-derived tumorospheres identify a population of tumor stem-like cells with angiogenic potential and enhanced multidrug resistance phenotype. Glia 2006; 54(8): 850-60. http://dx.doi.org/10.1002/glia.20414

[215] Hu Q, Gu G, Liu Z, Jiang M, Kang T, Miao D, et al. F3 peptide-functionalized PEG-PLA nanoparticles coadministrated with tLyp-1 peptide for anti-glioma drug delivery. Biomaterials 2013; 34(4): 1135-45. http://dx.doi.org/10.1016/j.biomaterials.2012.10.048

[216] Iwasaki K, Kikuchi H, Miyatake S, Aoki T, Yamasaki T, Oda $Y$. Infiltrative and cytolytic activities of lymphokine-activated killer cells against a human glioma spheroid model. Cancer Res 1990; 50(8): 2429-36.

[217] Kees T, Lohr J, Noack J, Mora R, Gdynia G, Tödt G, et al. Microglia isolated from patients with glioma gain antitumor activities on poly (I: C) stimulation. Neuro Oncol 2012; 14(1): 64-78.

http://dx.doi.org/10.1093/neuonc/nor182

[218] Sarkar S, Yong VW. Reduction of protein kinase C delta attenuates tenascin-C stimulated glioma invasion in threedimensional matrix. Carcinogenesis 2010; 31(2): 311-7. http://dx.doi.org/10.1093/carcin/bgp297

[219] Etminan N, Peters C, Lakbir D, Bünemann E, Börger V, Sabel MC, et al. Heat-shock protein 70-dependent dendritic cell activation by 5 -aminolevulinic acid-mediated photodynamic treatment of human glioblastoma spheroids in vitro. Br J Cancer 2011; 105(7): 961-9. http://dx.doi.org/10.1038/bjc.2011.327

[220] Biggs T, Foreman J, Sundstrom L, Regenass U, Lehembre F. Antitumor compound testing in glioblastoma organotypic brain cultures. J Biomol Screen 2011; 16(8): 805-17. http://dx.doi.org/10.1177/1087057111414895

[221] Preynat-Seauve O, Suter DM, Tirefort D, Turchi L, Virolle T, Chneiweiss $\mathrm{H}$, et al. Development of Human Nervous Tissue upon Differentiation of Embryonic Stem Cells in ThreeDimensional Culture. Stem Cells 2009; 27: 509-520. http://dx.doi.org/10.1634/stemcells.2008-0600

[222] Hirschhaeuser F, Menne H, Dittfeld C, West J, MuellerKlieser W, Kunz-Schughart LA. Multicellular tumor spheroids: an underestimated tool is catching up again. J Biotechnol 2010; 148(1): 3-15. http://dx.doi.org/10.1016/j.jbiotec. 2010.01.012

[223] Aaberg-Jessen C, Nørregaard A, Christensen K, Pedersen $\mathrm{CB}$, Andersen $\mathrm{C}$, Kristensen BW. Invasion of primary gliomaand cell line-derived spheroids implanted into corticostriatal slice cultures. Int J Clin Exp Pathol 2013; 6(4): 546-60.

[224] Carlsson J, Brunk U. The fine structure of three-dimensional colonies of human glioma cells in agarose culture. Acta Pathol Microbiol Scand A 1977; 85A(2): 183-92. http://dx.doi.org/10.1111/j.1699-0463.1977.tb00416.x

[225] Justice BA, Badr NA, Felder RA. 3D cell culture opens new dimensions in cell-based assays. Drug Discov Today 2009; 14(1-2): 102-7. http://dx.doi.org/10.1016/j.drudis.2008.11.006 
[226] Del Duca D, Werbowetski T, Del Maestro RF. Spheroid preparation from hanging drops: characterization of a model of brain tumor invasion. J Neurooncol 2004; 67(3): 295-303. http://dx.doi.org/10.1023/B:NEON.0000024220.07063.70

[227] Morrison LC, McClelland R, Aiken C, Bridges M, Liang L, Wang $\mathrm{X}$, et al. Deconstruction of medulloblastoma cellular heterogeneity reveals differences between the most highly invasive and self-renewing phenotypes. Neoplasia 2013; 15(4): 384-98.

[228] An Z, Gluck CB, Choy ML, Kaufman LJ. Suberoylanilide hydroxamic acid limits migration and invasion of glioma cells in two and three dimensional culture. Cancer Lett 2010; 292(2): 215-27.

http://dx.doi.org/10.1016/j.canlet.2009.12.006

[229] Ulrich TA, Jain A, Tanner K, MacKay JL, Kumar S. Probing cellular mechanobiology in three-dimensional culture with collagen-agarose matrices. Biomaterials 2010; 31(7): 187584.

\section{http://dx.doi.org/10.1016/j.biomaterials.2009.10.047}

[230] Sarkar S, Yong VW. Reduction of protein kinase C delta attenuates tenascin-C stimulated glioma invasion in threedimensional matrix. Carcinogenesis 2010; 31(2): 311-7. http://dx.doi.org/10.1093/carcin/bgp297

[231] Yang YL, Sun C, Wilhelm ME, Fox LJ, Zhu J, Kaufman LJ. Influence of chondroitin sulfate and hyaluronic acid on structure, mechanical properties, and glioma invasion of collagen I gels. Biomaterials 2011; 32(31): 7932-40. http://dx.doi.org/10.1016/j.biomaterials.2011.07.018

[232] Pedron S, Harley BA. Impact of the biophysical features of a 3D gelatin microenvironment on glioblastoma malignancy. $J$ Biomed Mater Res A 2013; 101(12): 3404-15. http://dx.doi.org/10.1002/jbm.a.34637

[233] Florczyk SJ, Wang K, Jana S, Wood DL, Sytsma SK, Sham JG, et al. Porous chitosan-hyaluronic acid scaffolds as a mimic of glioblastoma microenvironment ECM. Biomaterials 2013; 34(38): 10143-50. http://dx.doi.org/10.1016/j.biomaterials.2013.09.034

[234] Ananthanarayanan B, Kim Y, Kumar S. Elucidating the mechanobiology of malignant brain tumors using a brain matrix-mimetic hyaluronic acid hydrogel platform. Biomaterials 2011; 32(31): 7913-23. http://dx.doi.org/10.1016/j.biomaterials.2011.07.005

[235] David L, Dulong V, Coquerel B, Le Cerf D, Cazin L, Lamacz $\mathrm{M}$, et al. Collagens, stromal cell-derived factor-1alpha and basic fibroblast growth factor increase cancer cell invasiveness in a hyaluronan hydrogel. Cell Prolif 2008; 41(2): 348-64. http://dx.doi.org/10.1111/j.1365-2184.2008.00515.x

[236] Coquerel B, Poyer F, Torossian F, Dulong V, Bellon G, Dubus I, et al. Elastin-derived peptides: matrikines critical for glioblastoma cell aggressiveness in a 3-D system. Glia 2009; 57(16): 1716-26. http://dx.doi.org/10.1002/glia.20884

[237] Lutolf MP, Hubbell JA. Synthetic biomaterials as instructive extracellular microenvironments for morphogenesis in tissue engineering. Nat Biotechnol 2005; 23(1): 47-55.

http://dx.doi.org/10.1038/nbt1055

[238] Benson K, Galla HJ, Kehr NS. Cell Adhesion Behavior in 3D Hydrogel Scaffolds Functionalized with D- or L-Aminoacids. Macromol Biosci 2014. http://dx.doi.org/10.1002/mabi.201300485

[239] Ravi M, Sah S, Bhammar R. Differences of SiHa (human cancer of cervix) and BMG-1 (brain glioma) cell lines as 2D and 3D cultures. J Cell Physiol 2014; 229(2): 127-31. http://dx.doi.org/10.1002/jcp.24433

[240] Jiguet Jiglaire C, Baeza-Kallee N, Denicolaï E, Barets D, Metellus P, Padovani L, et al. Ex vivo cultures of glioblastoma in three-dimensional hydrogel maintain the original tumor growth behavior and are suitable for preclinical drug and radiation sensitivity screening. Exp Cell Res 2014; 321(2): 99-108.

http://dx.doi.org/10.1016/j.yexcr.2013.12.010

[241] Vajkoczy P, Menger MD, Goldbrunner R, Ge S, Fong TA, Vollmar $\mathrm{B}$, et al. Targeting angiogenesis inhibits tumor infiltration and expression of the pro-invasive protein SPARC. Int J Cancer 2000; 87(2): 261-8.

http://dx.doi.org/10.1002/1097-

0215(20000715)87:2<261::AID-IJC18>3.0.CO;2-6

[242] Ramis G, Thomàs-Moyà $E$, Fernández de Mattos $S$, Rodríguez J, Villalonga P. EGFR inhibition in glioma cells modulates Rho signaling to inhibit cell motility and invasion and cooperates with temozolomide to reduce cell growth. PLoS One 2012; 7(6): e38770. http://dx.doi.org/10.1371/journal.pone. 0038770

[243] de Ridder L, Cornelissen M, de Ridder D. Autologous spheroid culture: a screening tool for human brain tumor invasion. Crit Rev Oncol Hematol 2000; 36(2-3): 107-22. http://dx.doi.org/10.1016/S1040-8428(00)00081-0

[244] Harada T, Swift J, Irianto J, Shin JW, Spinler KR, Athirasala A, Diegmiller R, Dingal PC, Ivanovska IL, Discher DE. Nuclear lamin stiffness is a barrier to 3D migration, but softness can limit survival. J Cell Biol 2014; 204(5): 669-82. http://dx.doi.org/10.1083/jcb.201308029

[245] An Z, Gluck CB, Choy ML, Kaufman LJ. Suberoylanilide hydroxamic acid limits migration and invasion of glioma cells in two and three dimensional culture. Cancer Lett 2010; 292(2): 215-27. http://dx.doi.org/10.1016/j.canlet.2009.12.006

[246] Munson JM, Bellamkonda RV, Swartz MA. Interstitial flow in a 3D microenvironment increases glioma invasion by a CXCR4-dependent mechanism. Cancer Res 2013; 73(5): 1536-46. http://dx.doi.org/10.1158/0008-5472.CAN-12-2838

[247] Hoelzinger DB, Demuth T, Berens ME. Autocrine factors that sustain glioma invasion and paracrine biology in the brain microenvironment. J Natl Cancer Inst 2007; 99(21): 1583-93. http://dx.doi.org/10.1093/jnci/djm187

[248] Corcoran A, De Ridder LI, Del Duca D, Kalala OJ, Lah T, Pilkington GJ, et al. Evolution of the brain tumor spheroid model: transcending current model limitations. Acta Neurochir (Wien) 2003; 145(9): 819-24. http://dx.doi.org/10.1007/s00701-003-0096-0

[249] Pilkington GJ, Bjerkvig R, De Ridder L, Kaaijk P. In vitro and in vivo models for the study of brain tumor invasion. 1997; 17(6B): 4107-9.

[250] de Ridder L. Screening for invasion of the individual human brain tumor in an autologous confrontation system in vitro. Pathobiology 1999; 67(3): 133-9.

http://dx.doi.org/10.1159/000028063

[251] Lakka SS, Jasti SL, Gondi C, Boyd D, Chandrasekar N, Dinh $\mathrm{DH}$, et al. Downregulation of MMP-9 in ERK-mutated stable transfectants inhibits glioma invasion in vitro. Oncogene 2002; 21(36): 5601-8.

http://dx.doi.org/10.1038/sj.onc. 1205646

[252] Khoshyomn S, Penar PL, McBride WJ, Taatjes DJ. Fourdimensional analysis of human brain tumor spheroid invasion into fetal rat brain aggregates using confocal scanning laser microscopy. J Neurooncol 1998; 38(1): 1-10. http://dx.doi.org/10.1023/A:1005758626348

[253] de Ridder L. Autologous confrontation of brain tumor derived spheroids with human dermal spheroids. Anticancer Res. 1997; 17(6B): 4119-20.

[254] Maes L, Kalala JP, Cornelissen M, de Ridder L. Progression of astrocytomas and meningiomas: an evaluation in vitro. Cell Prolif 2007; 40(1): 14-23. http://dx.doi.org/10.1111/j.1365-2184.2007.00415.x

[255] Lah TT, Nanni I, Trinkaus M, Metellus P, Dussert C, De Ridder $\mathrm{L}$, et al. Toward understanding recurrent meningioma: 
the potential role of lysosomal cysteine proteases and their inhibitors. J Neurosurg 2010; 112(5): 940-50. http://dx.doi.org/10.3171/2009.7.JNS081729

[256] Oellers $P$, Schallenberg $M$, Stupp $T$, Charalambous $P$, Senner $\mathrm{V}$, Paulus $\mathrm{W}$, et al. A coculture assay to visualize and monitor interactions between migrating glioma cells and nerve fibers. Nat Protoc 2009; 4(6): 923-7. http://dx.doi.org/10.1038/nprot.2009.62

[257] de Ridder L, Calliauw L. Invasiveness of primary and secondary brain tumors in vitro correlated with clinical results. Neurosurgery 1992; 31(6): 1043-8. http://dx.doi.org/10.1227/00006123-199212000-00009

[258] Bouterfa H, Picht T, Kess D, Herbold C, Noll E, Black PM, et al. Retinoids inhibit human glioma cell proliferation and migration in primary cell cultures but not in established cell lines. Neurosurgery 2000; 46(2): 419-30.

http://dx.doi.org/10.1097/00006123-200002000-00029

[259] Matsumura $H$, Ohnishi $T$, Kanemura $Y$, Maruno $M$, Yoshimine T. Quantitative analysis of glioma cell invasion by confocal laser scanning microscopy in a novel brain slice model. Biochem Biophys Res Commun 2000; 269(2): 51320.

\section{http://dx.doi.org/10.1006/bbrc.2000.2332}

[260] Agudelo-Garcia PA, De Jesus JK, Williams SP, Nowicki MO, Chiocca EA, Liyanarachchi S, et al. Glioma cell migration on three-dimensional nanofiber scaffolds is regulated by substrate topography and abolished by inhibition of STAT3 signaling. Neoplasia 2011; 13(9): 831-40.

[261] Ingram M, Techy GB, Saroufeem R, Yazan O, Narayan KS, Goodwin TJ, et al. Three-dimensional growth patterns of various human tumor cell lines in simulated microgravity of a NASA Bioreactor. In vitro Cell Dev Biol Animal 1997; 33: 45966. http://dx.doi.org/10.1007/s11626-997-0064-8

[262] Smith SJ, Wilson M, Ward JH, Rahman CV, Peet AC, Macarthur DC, et al. Recapitulation of tumor heterogeneity and molecular signatures in a 3D brain cancer model with decreased sensitivity to histone deacetylase inhibition. PLoS One 2012; 7(12): e52335.

http://dx.doi.org/10.1371/journal.pone.0052335

[263] Panchalingam KM, Paramchuk WJ, Chiang CY, Shah N, Madan A, Hood L, et al. Bioprocessing of human glioblastoma brain cancer tissue. Tissue Eng Part A 2010; 16(4): 1169-77.

http://dx.doi.org/10.1089/ten.tea.2009.0490

[264] Trouard TP, Harkins KD, Divijak JL, Gillies RJ, Galons JP. Ischemia-induced changes of intracellular water diffusion in rat glioma cell cultures. Magn Reson Med 2008; 60(2): 25864. http://dx.doi.org/10.1002/mrm.21616

[265] Lee $\mathrm{KH}$, Lee $\mathrm{KH}$, Lee J, Choi $\mathrm{H}$, Lee $\mathrm{D}$, Park $\mathrm{Y}$, et al. Integration of microfluidic chip with biomimetic hydrogel for $3 \mathrm{D}$ controlling and monitoring of cell alignment and migration. J Biomed Mater Res A 2014; 102(4): 1164-72. http://dx.doi.org/10.1002/jbm.a.34772

[266] Huang Y, Agrawal B, Clark PA, Williams JC, Kuo JS. Evaluation of cancer stem cell migration using compartmentalizing microfluidic devices and live cell imaging. J Vis Exp 2011; 58: e3297.

[267] Rambani K, Vukasinovic J, Glezer A, Potter SM. Culturing thick brain slices: an interstitial 3D microperfusion system for enhanced viability. J Neurosci Methods 2009; 180(2): 243-54 http://dx.doi.org/10.1016/j.jneumeth.2009.03.016

[268] Ma L, Barker J, Zhou C, Li W, Zhang J, Lin B, et al. Towards personalized medicine with a three-dimensional micro-scale perfusion-based two-chamber tissue model system. Biomaterials 2012; 33(17): 4353-61. http://dx.doi.org/10.1016/j.biomaterials.2012.02.054
[269] Paguirigan AL, Beebe DJ. Microfluidics meet cell biology: bridging the gap by validation and application of microscale techniques for cell biological assays. Bioessays 2008; 30(9): 811-21.

http://dx.doi.org/10.1002/bies.20804

[270] Vaira V, Fedele G, Pyne S, Fasoli E, Zadra G, Baily D, et al. Preclinical model of organotypic culture for pharmacodynamic profiling of human tumors. Proc Natl Acad Sci USA 2010; 107: 8352-8356. http://dx.doi.org/10.1073/pnas.0907676107

[271] Joshi K, Demir H, Yamada R, Miyazaki T, Ray-Chaudhury A, Nakano I. Method for novel anti-cancer drug development using tumor explants of surgical specimens. J Vis Exp 2011; 53.

[272] Maris JM. Recent advances in neuroblastoma. N Engl J Med 2010; 362(23): 2202-11. http://dx.doi.org/10.1056/NEJMra0804577

[273] Park JR, Bagatell R, London WB, Maris JM, Cohn SL, Mattay $\mathrm{KM}$, et al. COG Neuroblastoma Committee. Children's Oncology Group's 2013 blueprint for research: neuroblastoma. Pediatr Blood Cancer 2013; 60(6): 985-93. http://dx.doi.org/10.1002/pbc.24433

[274] Schramm A, Schulte JH, Astrahantseff K, Apostolov O, Limpt $\mathrm{Vv}$, Sieverts $\mathrm{H}$, et al. Biological effects of TrkA and TrkB receptor signaling in neuroblastoma. Cancer Lett 2005; 228(1-2): 143-53.

http://dx.doi.org/10.1016/j.canlet.2005.02.051

[275] Pistoia V, Morandi F, Bianchi G, Pezzolo A, Prigione I, Raffaghello L. Immunosuppressive microenvironment in neuroblastoma. Front Oncol 2013; 3: 167. http://dx.doi.org/10.3389/fonc. 2013.00167

[276] Cheung NK, Dyer MA. Neuroblastoma: developmental biology, cancer genomics and immunotherapy. Nat Rev Cancer 2013; 13(6): 397-411. http://dx.doi.org/10.1038/nrc3526

[277] Seeger RC. Immunology and immunotherapy of neuroblastoma. Semin Cancer Biol 2011; 21(4): 229-37. http://dx.doi.org/10.1016/j.semcancer.2011.09.012

[278] Pistoia V, Bianchi G, Borgonovo G, Raffaghello L. Cytokines in neuroblastoma: from pathogenesis to treatment. Immunotherapy 2011; 3(7): 895-907.

http://dx.doi.org/10.2217/imt.11.80

[279] Hussein D, Estlin EJ, Dive C, Makin GW. Chronic hypoxia promotes hypoxia-inducible factor-1alpha-dependent resistance to etoposide and vincristine in neuroblastoma cells. Mol Cancer Ther 2006; 5(9): 2241-50. http://dx.doi.org/10.1158/1535-7163.MCT-06-0145

[280] Das B, Yeger H, Tsuchida R, Torkin R, Gee MF, Thorner PS, et al. A hypoxia-driven vascular endothelial growth factor/FIt1 autocrine loop interacts with hypoxia-inducible factor-1alpha through mitogen-activated protein kinase/extracellular signalregulated kinase $1 / 2$ pathway in neuroblastoma. Cancer Res 2005; 65(16): 7267-75.

http://dx.doi.org/10.1158/0008-5472.CAN-04-4575

[281] Fardin P, Barla A, Mosci S, Rosasco L, Verri A, Versteeg R, et al. A biology-driven approach identifies the hypoxia gene signature as a predictor of the outcome of neuroblastoma patients. Mol Cancer 2010; 9: 185. http://dx.doi.org/10.1186/1476-4598-9-185

[282] Liao D, Johnson RS. Hypoxia: a key regulator of angiogenesis in cancer. Cancer Metastasis Rev 2007; 26(2): 281-90.

\section{http://dx.doi.org/10.1007/s10555-007-9066-y}

[283] Eggert A, Ikegaki N, Kwiatkowski J, Zhao H, Brodeur GM, Himelstein BP. High-level expression of angiogenic factors is associated with advanced tumor stage in human neuroblastomas. Clin Cancer Res 2000; 6(5): 1900-8. 
[284] Burchill SA. Micrometastases in neuroblastoma: are they clinically important? J Clin Pathol 2004; 57(1): 14-20. http://dx.doi.org/10.1136/jcp.57.1.14

[285] Maman S, Edry-Botzer L, Sagi-Assif O, Meshel T, Yuan W, Lu W, et al. The metastatic microenvironment: lung-derived factors control the viability of neuroblastoma lung metastasis. Int J Cancer 2013; 133(10): 2296-306. http://dx.doi.org/10.1002/ijc.28255

[286] Sohara Y, Shimada H, DeClerck YA. Mechanisms of bone invasion and metastasis in human neuroblastoma. Cancer Lett 2005; 228(1-2): 203-9. http://dx.doi.org/10.1016/j.canlet.2005.01.059

[287] Airoldi I, Cocco C, Morandi F, Prigione I, Pistoia V. CXCR5 may be involved in the attraction of human metastatic neuroblastoma cells to the bone marrow. Cancer Immunol Immunother 2008; 57(4): 541-8.

http://dx.doi.org/10.1007/s00262-007-0392-2

[288] Scaruffi P, Morandi F, Gallo F, Stigliani S, Parodi S, Moretti $\mathrm{S}$, et al. Bone marrow of neuroblastoma patients shows downregulation of CXCL12 expression and presence of IFN signature. Pediatr Blood Cancer 2012; 59(1): 44-51.

http://dx.doi.org/10.1002/pbc.23339

[289] Kumar HR, Zhong X, Hoelz DJ, Rescorla FJ, Hickey RJ, Malkas $\mathrm{LH}$, et al. Three-dimensional neuroblastoma cell culture: proteomic analysis between monolayer and multicellular tumor spheroids. Pediatr Surg Int 2008; 24(11): 1229-34.

http://dx.doi.org/10.1007/s00383-008-2245-2

[290] Jung GS, Lee KM, Park JK, Choi SK, Jeon WB. Morphogenetic and neuronal characterization of human neuroblastoma multicellular spheroids cultured under undifferentiated and all-trans-retinoic acid-differentiated conditions. BMB Rep 2013; 46(5): 276-81. http://dx.doi.org/10.5483/BMBRep.2013.46.5.196

[291] Bilir A, Erguven M, Yazihan N, Aktas E, Oktem G, Sabanci A. Enhancement of vinorelbine-induced cytotoxicity and apoptosis by clomipramine and lithium chloride in human neuroblastoma cancer cell line SH-SY5Y. J Neurooncol 2010; 100(3): 385-95.

http://dx.doi.org/10.1007/s11060-010-0209-6

[292] Russell J, Wheldon TE, Stanton P. A radioresistant variant derived from a human neuroblastoma cell line is less prone to radiation-induced apoptosis. Cancer Res 1995; 55(21): 4915-21.

[293] Cunningham SH, Mairs RJ, Wheldon TE, Welsh PC, Vaidyanathan G, Zalutsky MR. Toxicity to neuroblastoma cells and spheroids of benzylguanidine conjugated to radionuclides with short-range emissions. $\mathrm{Br} \mathrm{J}$ Cancer 1998; 77(12): 2061-8. http://dx.doi.org/10.1038/bjc.1998.348

[294] Canaparo R, Varchi G, Ballestri M, Foglietta F, Sotgiu G, Guerrini $A$, et al. Polymeric nanoparticles enhance the sonodynamic activity of meso-tetrakis (4-sulfonatophenyl) porphyrin in an in vitro neuroblastoma model. Int $\mathrm{J}$ Nanomedicine 2013; 8: 4247-63.

[295] Collins SL, Hervé R, Keevil CW, Blaydes JP, Webb JS. Down-regulation of DNA mismatch repair enhances initiation and growth of neuroblastoma and brain tumor multicellular spheroids. PLoS One 2011; 6(12): e28123. http://dx.doi.org/10.1371/journal.pone.0028123

[296] Biedler JL, Helson L, Spengler BA. Morphology and growth, tumorigenicity, and cytogenetics of human neuroblastoma cells in continuous culture. Cancer Res 1973; 33: 2643-52.

[297] Påhlman S, Hoehner JC, Nånberg E, Hedborg F, Fagerström $\mathrm{S}$, Gestblom C, et al. Differentiation and survival influences of growth factors in human neuroblastoma. Eur J Cancer 1995; 31A: 453-458.

http://dx.doi.org/10.1016/0959-8049(95)00033-F
[298] Encinas M, Iglesias M, Liu Y, Wang H, Muhaisen A, Ceña V, et al. Sequential treatment of SH-SY5Y cells with retinoic acid and brain-derived neurotrophic factor gives rise to fully differentiated, neurotrophic factor-dependent, human neuronlike cells. J Neurochem 2000; 75: 991-1003. http://dx.doi.org/10.1046/j.1471-4159.2000.0750991.x

[299] Seidel D, Krinke D, Jahnke HG, Hirche A, Kloß D, Mack TG, Striggow F, Robitzki A. Induced tauopathy in a novel 3Dculture model mediates neurodegenerative processes: a realtime study on biochips. PLoS One 2012; 7(11): e49150. http://dx.doi.org/10.1371/journal.pone.0049150

[300] Farina AR, Masciulli MP, Tacconelli A, Cappabianca L, De Santis G, Gulino A, et al. All-trans-retinoic acid induces nuclear factor kappaB activation and matrix metalloproteinase- 9 expression and enhances basement membrane invasivity of differentiation-resistant human SK-NBE 9N neuroblastoma Cells. Cell Growth Differ 2002; 13(8): 343-54.

[301] Zaizen Y, Taniguchi S, Suita S. The role of cellular motility in the invasion of human neuroblastoma cells with or without $\mathrm{N}$ myc amplification and expression. J Pediatr Surg 1998; 33(12): 1765-70.

http://dx.doi.org/10.1016/S0022-3468(98)90281-0

[302] Voigt A, Zintl F. Effects of retinoic acid on proliferation, apoptosis, cytotoxicity, migration, and invasion of neuroblastoma cells. Med Pediatr Oncol 2003; 40(4): 205-13. http://dx.doi.org/10.1002/mpo.10250

[303] Hecht M, Schulte JH, Eggert A, Wilting J, Schweigerer L. The neurotrophin receptor TrkB cooperates with c-Met in enhancing neuroblastoma invasiveness. Carcinogenesi 2005; 26(12): 2105-15. http://dx.doi.org/10.1093/carcin/bgi192

[304] Lu HF, Lai KC, Hsu SC, Lin HJ, Kuo CL, Liao CL, et al. Involvement of matrix metalloproteinases on the inhibition of cells invasion and migration by emodin in human neuroblastoma SH-SY5Y cells. Neurochem Res 2009; 34(9): 1575-83. http://dx.doi.org/10.1007/s11064-009-9946-3

[305] Timeus F, Crescenzio N, Doria A, Foglia L, Pagliano S, Ricotti $\mathrm{E}$, et al. In vitro anti-neuroblastoma activity of saquinavir and its association with imatinib. Oncol Rep 2012; 27(3): 734-40.

[306] Waheed Roomi M, Kalinovsky T, Roomi NW, Niedzwiecki A Rath M. Inhibition of the SK-N-MC human neuroblastoma cell line in vivo and in vitro by a novel nutrient mixture. Oncol Rep 2013; 29(5): 1714-20.

[307] Zhong J, Bach CT, Shum MS, O'Neill GM. NEDD9 regulates 3D migratory activity independent of the Rac1 morphology switch in glioma and neuroblastoma. Mol Cancer Res 2014; 12(2): 264-73.

http://dx.doi.org/10.1158/1541-7786.MCR-13-0513

[308] Jadhav U, Mohanam S. Response of neuroblastoma cells to ionizing radiation: modulation of in vitro invasiveness and angiogenesis of human microvascular endothelial cells. Int $\mathrm{J}$ Oncol 2006; 29(6): 1525-31.

[309] Mao C, Kisaalita WS. Characterization of 3-D collagen hydrogels for functional cell-based biosensing. Biosens Bioelectron 2004; 19(9): 1075-88.

http://dx.doi.org/10.1016/j.bios.2003.10.008

[310] Valero T, Moschopoulou G, Kintzios S, Hauptmann P, Naumann M, Jacobs T. Studies on neuronal differentiation and signalling processes with a novel impedimetric biosensor. Biosens Bioelectron 2010; 26(4): 1407-13. http://dx.doi.org/10.1016/j.bios.2010.07.066

[311] Innala M, Riebe I, Kuzmenko V, Sundberg J, Gatenholm P, Hanse $\mathrm{E}$, et al. 3D Culturing and differentiation of SH-SY5Y neuroblastoma cells on bacterial nanocellulose scaffolds. Artif Cells Nanomed Biotechnol 2013; doi:10.3109/ 21691401.2013.821410. 
[312] Wu ZZ, Wang ZW, Zhang LG, An ZX, Zhong DH, Huang QP et al. Responsiveness of voltage-gated calcium channels in SH-SY5Y human neuroblastoma cells on quasi-threedimensional micropatterns formed with poly (I-lactic acid). Int J Nanomedicine 2013; 8: 93-107. http://dx.doi.org/10.2147//JN.S38362

[313] Melissinaki V, Gill AA, Ortega I, Vamvakaki M, Ranella A, Haycock JW, et al. Direct laser writing of 3D scaffolds for neural tissue engineering applications. Biofabrication 2011; 3(4): 045005.

http://dx.doi.org/10.1088/1758-5082/3/4/045005

[314] Kullenberg J, Rosatini F, Vozzi G, Bianchi F, Ahluwalia A, Domenici C. Optimization of PAM scaffolds for neural tissue engineering: preliminary study on an SH-SY5Y cell line. Tissue Eng Part A 2008; 14(6): 1017-23. http://dx.doi.org/10.1089/ten.tea.2007.0163

[315] Jain S, Sharma A, Basu B. In vitro cytocompatibility assessment of amorphous carbon structures using neuroblastoma and Schwann cells. J Biomed Mater Res B Appl Biomater 2013; 101(4): 520-31.

http://dx.doi.org/10.1002/jbm.b.32852

[316] Chen W, Tong YW. PHBV microspheres as neural tissue engineering scaffold support neuronal cell growth and axondendrite polarization. Acta Biomater 2012; 8(2): 540-8. http://dx.doi.org/10.1016/j.actbio.2011.09.026

[317] Redden RA, Doolin EJ. Microgravity assay of neuroblastoma: in vitro aggregation kinetics and organoid morphology correlate with MYCN expression. In vitro Cell Dev Biol Anim 2011; 47(4): 312-7.

http://dx.doi.org/10.1007/s11626-011-9393-8

[318] Redden RA, lyer R, Brodeur GM, Doolin EJ. Rotary bioreactor culture can discern specific behavior phenotypes in Trk-null and Trk-expressing neuroblastoma cell lines. In vitro Cell Dev Biol Anim 2014; 50(3): 188-93. http://dx.doi.org/10.1007/s11626-013-9716-z

[319] Rujkijyanont P, Chan WK, Eldridge PW, Lockey T, Holladay $\mathrm{M}$, Rooney $\mathrm{B}$, et al. Ex vivo activation of CD56(+) immune cells that eradicate neuroblastoma. Cancer Res 2013; 73(8): 2608-18.

http://dx.doi.org/10.1158/0008-5472.CAN-12-3322

[320] Voronov E, Shouval DS, Krelin Y, Cagnano E, Benharroch D, Iwakura $\mathrm{Y}$, et al. IL-1 is required for tumor invasiveness and angiogenesis. Proc Natl Acad Sci USA 2003; 100(5): 264550 .

http://dx.doi.org/10.1073/pnas.0437939100

[321] Xu K, Rajagopal S, Klebba I, Dong S, Ji Y, Liu J, et al. The role of fibroblast Tiam1 in tumor cell invasion and metastasis. Oncogene. 2010; 29(50): 6533-42.

http://dx.doi.org/10.1038/onc.2010.385

[322] Goswami S, Sahai E, Wyckoff JB, Cammer M, Cox D, Pixley $\mathrm{FJ}$, et al. Macrophages promote the invasion of breast carcinoma cells via a colony-stimulating factor-1/epidermal growth factor paracrine loop. Cancer Res. 2005; 65(12): 5278-83. Erratum in: Cancer Res 2005; 65(15): 7031. http://dx.doi.org/10.1158/0008-5472.CAN-04-1853

[323] Niggemann B, Drell TL 4th, Joseph J, Weidt C, Lang K, Zaenker KS, et al. Tumor cell locomotion: differential dynamics of spontaneous and induced migration in a 3D collagen matrix. Exp Cell Res 2004; 298(1): 178-87. http://dx.doi.org/10.1016/j.yexcr.2004.04.001

[324] Castello-Cros R, Khan DR, Simons J, Valianou M, Cukierman E. Staged stromal extracellular 3D matrices differentially regulate breast cancer cell responses through $\mathrm{PI} 3 \mathrm{~K}$ and beta1-integrins. BMC Cancer. BMC Cancer 2009; 26; 9: 94.

[325] Debnath J, Brugge JS. Modelling glandular epithelial cancers in three-dimensional cultures. Nat Rev Cancer 2005; 5: 67588.

http://dx.doi.org/10.1038/nrc1695
[326] Curtin P, Youm H, Salih E. Three-dimensional cancer-bone metastasis model using ex vivo co-cultures of live calvarial bones and cancer cells. Biomaterials 2012; 33(4): 1065-78. http://dx.doi.org/10.1016/j.biomaterials.2011.10.046

[327] Fjellbirkeland L, Bjerkvig R, Laerum OD. Non-small-cell lung carcinoma cells invade human bronchial mucosa in vitro. In vitro Cell Dev Biol Anim 1998; 34(4): 333-40. http://dx.doi.org/10.1007/s11626-998-0010-4

[328] Bersini S, Jeon JS, Dubini G, Arrigoni C, Chung S, Charest $\mathrm{JL}$, et al. A microfluidic $3 \mathrm{D}$ in vitro model for specificity of breast cancer metastasis to bone. Biomaterials 2014; 35(8): 2454-61.

http://dx.doi.org/10.1016/j.biomaterials.2013.11.050

[329] Quail DF, Maciel TJ, Rogers K, Postovit LM. A unique 3D in vitro cellular invasion assay. J Biomol Screen 2012; 17(8): 1088-95.

http://dx.doi.org/10.1177/1087057112449863

[330] Yoshii Y, Waki A, Yoshida K, Kakezuka A, Kobayashi M, Namiki $\mathrm{H}$, et al. The use of nanoimprinted scaffolds as 3D culture models to facilitate spontaneous tumor cell migration and well-regulated spheroid formation. Biomaterials 2011; 32(26): 6052-8.

[331] Nakatsu MN, Sainson RC, Aoto JN, Taylor KL, Aitkenhead $\mathrm{M}$, Perez-del-Pulgar $\mathrm{S}$, et al. Angiogenic sprouting and capillary lumen formation modeled by human umbilical vein endothelial cells (HUVEC) in fibrin gels: The role of fibroblasts and Angiopoietin-1. Microvasc. Res 2003; 66: 102-112.

http://dx.doi.org/10.1016/S0026-2862(03)00045-1

[332] Nicosia RF, Ottinetti A. Modulation of microvascular growth and morphogenesis by reconstituted basement membrane gel in threedimensional cultures of rat aorta: a comparative study of angiogenesi in matrigel, collagen, fibrin, and plasma clot. In vitro Cell Dev Biol 1990; 26: 119-28.

http://dx.doi.org/10.1007/BF02624102

[333] Blacher S, Devy L, Noel A, Foidart J-M. Quantification of angiogenesis on the rat aortic ring assay. Image Anal Tereol 2003; 22: 43-48.

http://dx.doi.org/10.5566/ias.v22.p43-48

[334] Muthukkaruppan VR, Shinners BL, Lewis R, Park S-J, Baechler BJ, Auerbach R. The chick embryo aortic arch assay: a new, rapid, quantifiable in vitro method for testing the efficacy of angiogenic and anti-angiogenic factors in a three-dimensional, serum-free organ culture system. Proc Am Assoc Cancer Res 2000; 41: 65.

[335] Hetheridge C, Mavria G, Mellor H. Uses of the in vitro endothelial-fibroblast organotypic co-culture assay in angiogenesis research. Biochem Soc Trans 2011; 39(6): 1597-600. http://dx.doi.org/10.1042/BST20110738

[336] Loessner D, Stok KS, Lutolf MP, Hutmacher DW, Clements JA, Rizzi SC. Bioengineered 3D platform to explore cell-ECM interactions and drug resistance of epithelial ovarian cancer cells. Biomaterials. 2010 Nov; 31(32): 8494-506. http://dx.doi.org/10.1016/j.biomaterials.2010.07.064

[337] Leeper AD, Farrell J, Williams LJ, Thomas JS, Dixon JM, Wedden SE, et al. Determining tamoxifen sensitivity using primary breast cancer tissue in collagen-based threedimensional culture. Biomaterials 2012; 33(3): 907-15. http://dx.doi.org/10.1016/j.biomaterials.2011.10.028

[338] Yip D, Cho CH. A multicellular 3D heterospheroid model of liver tumor and stromal cells in collagen gel for anti-cancer drug testing. Biochem Biophys Res Commun 2013; 433(3): 327-32.

http://dx.doi.org/10.1016/j.bbrc.2013.03.008

[339] Ziółkowska K, Stelmachowska A, Kwapiszewski R, Chudy M, Dybko A, Brzózka Z. Long-term three-dimensional cell culture and anticancer drug activity evaluation in a microfluidic chip. Biosens Bioelectron 2013; 40(1): 68-74. http://dx.doi.org/10.1016/j.bios.2012.06.017 
[340] van der Kuip $H$, Mürdter TE, Sonnenberg M, McClellan M, Gutzeit S, Gerteis A, et al. Short term culture of breast cancer tissues to study the activity of the anticancer drug taxol in an intact tumor environment. BMC Cancer 2006; 6: 86.

http://dx.doi.org/10.1186/1471-2407-6-86

[341] Reddy JK, Kanwar YS, Rao MS, Watanabe TK, Reddy MK, Parsa I, et al. Duct-like morphogenesis of Longnecker pancreatic acinar carcinoma cells maintained in vitro on seminiferous tubular basement membranes. Cancer Res 1986; 46(1): 347-54.

[342] Ingber DE, Madri JA, Jamieson JD. Basement membrane as a spatial organizer of polarized epithelia. Exogenous basement membrane reorients pancreatic epithelial tumor cells in vitro. Am J Pathol 1986; 122: 129-39.

Received on 01-05-2014

Accepted on 16-05-2014

Published on 30-06-2014

DOI: http://dx.doi.org/10.14205/2309-3021.2014.02.01.5

(c) 2014 Steimberg et al.; Licensee Pharma Publisher.

This is an open access article licensed under the terms of the Creative Commons Attribution Non-Commercial License (http://creativecommons.org/licenses/by-nc/3.0/) which permits unrestricted, non-commercial use, distribution and reproduction in any medium, provided the work is properly cited. 